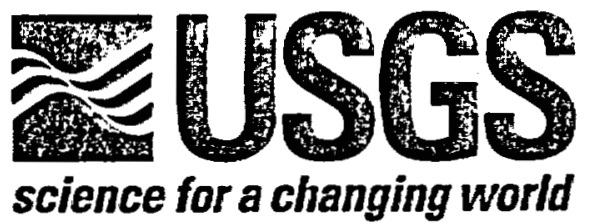

\title{
WATER LEVELS IN THE YUCCA MOUNTAIN AREA, NEVADA, 1996
}

\section{U.S. GEOLOGICAL SURVEY}

Open-File Report 98-169

Prepared in cooperation with the NEVADA OPERATIONS OFFICE, U.S. DEPARTMENT OF ENERGY, under Interagency Agreement DE-Al08-97NV12033 


\title{
Water Levels in the Yucca Mountain Area, Nevada, 1996
}

\author{
by Robert P. Graves
}

\section{U.S. GEOLOGICAL SURVEY}

Open-File Report 98-169

Prepared in cooperation with the NEVADA OPERATIONS OFFICE, U.S. DEPARTMENT OF ENERGY, under Interagency Agreement DE-A108-97NV12033 


\title{
U.S. DEPARTMENT OF THE INTERIOR BRUCE BABBITT, Secretary
}

\author{
U.S. GEOLOGICAL SURVEY
}

Thomas J. Casadevall, Acting Director

The use of firm, trade, and brand names in this report is for identification purposes only and does not constitute endorsement by the U.S. Geological Survey.

For additional information write to:

Chief, Earth Science Investigations Program Vucca Mountain Project Branch

U.S. Geological Survey

Box 25046, Mail Stop 421

Denver Federal Center

Denver, CO 80225-0046
Copies of this report can be purchased from:

U.S. Geological Survey

Information Services

Box 25286

Federal Center

Denver, CO 80225 


\section{CONTENTS}

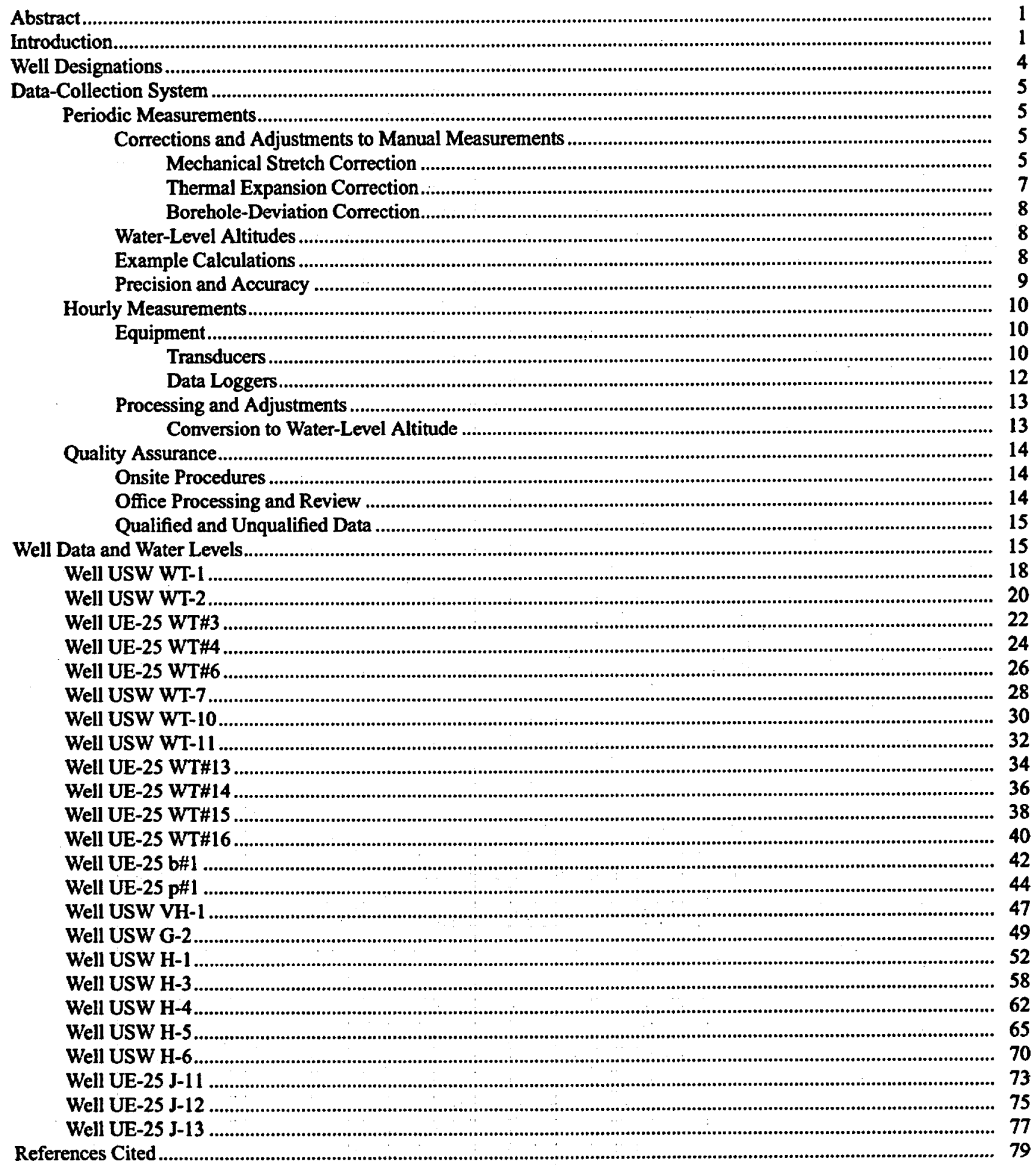




\section{FIGURES}

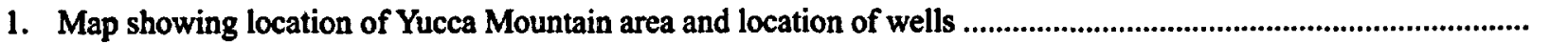

2-32. Hydrographs showing water-level altitudes, 1996, for:

2. Well USW WT-1

3. Well USW WT-2

4. Well UE-25 WT\#3

5. Well UE-25 WT\#4

6. Well UE-25 WTH6

7. Well USW WT-7

8. Well USW WT-10

9. Well USW WT-11

10. Well UE-25 WT\#13

11. Well UE-25 WT\#14

12. Well UE-25 WT\#15.

13. Well UE-25 WT\#16.

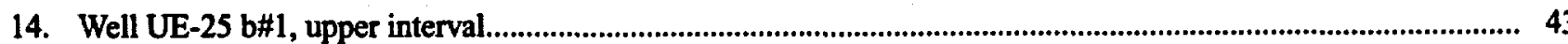

15. Well UE-25 p\#1

16. Well USW VH-1

17. Well USW G-2

18. Well USW H-1, tube 1

19. Well USW H-1, tube 2

20. Well USW H-1, tube 3

21. Well USW H-1, tube 4

22. Well USW H-3, upper interval

23. Well USW H-3, lower interval

24. Well USW H-4, upper interval

25. Well USW H-4, lower interval

26. Well USW H-5, upper interval

27. Well USW H-5, lower interval

28. Well USW H-6, upper interval

29. Well USW H-6, lower interval

30. Well UE-25 J-11

31. Well UE-25 J-12.

32. Well UE-25 J-13

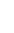

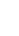




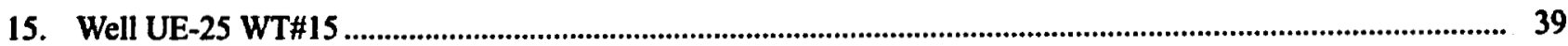

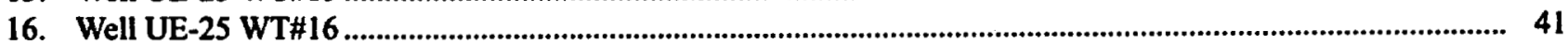

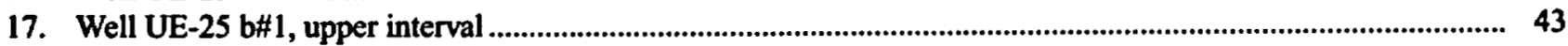

18. Monthly mean water-level altitudes, 1996, for well UE-25 p \#1 .....................................................................4. 46

19-29. Measured water-level altitudes, 1996, for:

19. Well UE-25 p\#1

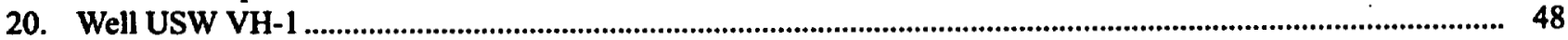

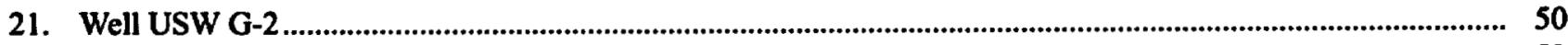

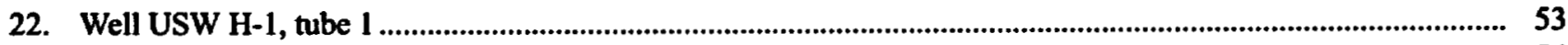

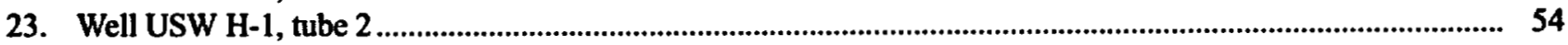

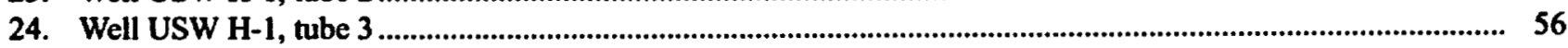

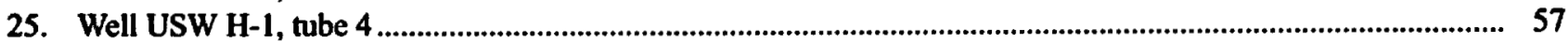

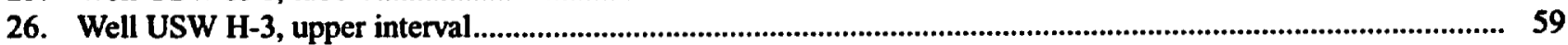

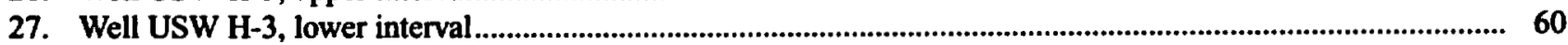

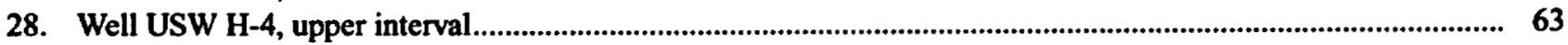

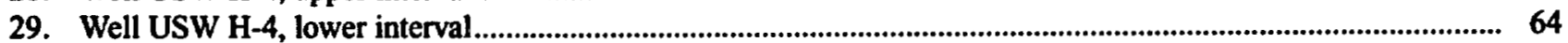

30. Monthly mean water-level altitudes, 1996, from daily mean water levels for well USW H-5,

31. Measured water-level altitudes, 1996, for well USW H-5, upper interval........................................................ 67

32. Monthly mean water-level altitudes, 1996, from daily mean water levels for well USW H-5,

33-38. Measured water-level altitudes, 1996, for:

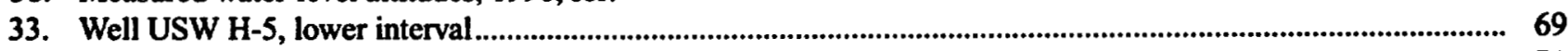

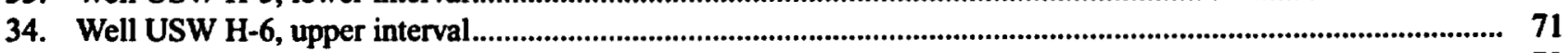

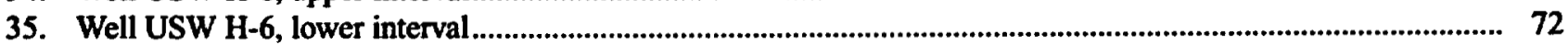

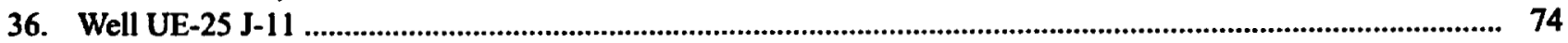

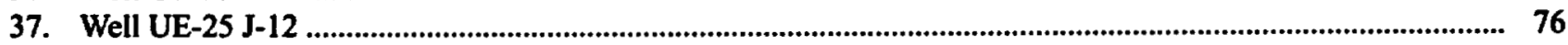

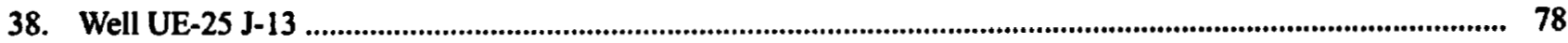

\section{CONVERSION FACTORS AND VERTICAL DATUM}

\begin{tabular}{rll}
\hline Multiply & By & To obtain \\
\hline meter $(\mathrm{m})$ & 3.281 & foot \\
millimeter $(\mathrm{mm})$ & 0.03937 & inch \\
kilometer $(\mathbf{k m})$ & 0.6214 & mile \\
square kilometer $\left(\mathrm{km}^{2}\right)$ & 0.3861 & square mile \\
liter $(\mathrm{L})$ & 0.03531 & cubic foot \\
pound per square inch $(\mathrm{psi})$ & 703.1 & kilogram per square meter \\
\hline
\end{tabular}

Sea level: In this report "sea level" refers to the National Geodetic Vertical Datum of 1929 (NGVD of 1929)—a geodetic datum derived from a general adjustment of the first-order level nets of both the United States and Canada, formerly called Sea Level Datum of 1929. 


\title{
Water Levels in the Yucca Mountain Area, Nevada, 1996
}

\author{
By Robert P. Graves
}

ABSTRACT

Water levels were monitored in 24 wells in the Yucca Mountain area, Nevada, during 1996. Twenty-two wells representing 28 depth intervals were monitored periodically, generally on a monthly basis, and 2 wells representing 3 depth intervals were monitored both hourly and periodically. All wells monitor water levels in Tertiary volcanic rocks except one that monitors water levels in Paleozoic carbonate rocks. Water levels were measured using either calibrated steel tapes or a pressure sensor.

Mean water-level altitudes in the Tertiary volcanic rocks ranged from about 727.86 to about 1,034.58 meters above sea level during 1996. The mean water-level altitude in the well monitoring the Paleozoic carbonate rocks was about 752.57 meters above sea level during 1996. Mean water-level altitudes for 1996 were an average of about 0.06 meter lower than 1995 mean water-level altitudes and 0.03 meter lower than $1985-95$ mean water-level altitudes.

During 1996, water levels in the Yucca Mountain area could have been affected by long-term pumping at the C-hole complex that began on May 8, 1996. Through December 31, 1996, approximately 196 million liters were pumped from well UE-25 c\#3 at the C-hole complex. Other ground-water pumpage in the Yucca Mountain area includes annual pumpage from water-supply wells UE-25 J-12 and UE-25 J-13 of approximately 163 and 105 million liters, respectively, and pumpage from well USW G-2 for hydraulic testing during February and April 1996 of approximately 6 million liters.

\section{INTRODUCTION}

The Yucca Mountain area is being evaluated by the U.S. Department of Energy for suitability to store highlevel nuclear waste in a mined, underground repository. A $150-\mathrm{km}^{2}$ area located about $150 \mathrm{~km}$ northwest of Las Vegas in southern Nevada is being studied extensively (fig. 1). Water levels in selected wells have been measured periodically since 1981 . The purpose of the water-level monitoring program is to gain a better understanding of the ground-water flow system in the area. The water-level data can be used to determine the direction and rate of ground-water flow and to estimate hydraulic parameters of the flow system. In the Yucca Mountain area, the water table is in air-fall and ash-flow tuffs of Tertiary age. Saturated carbonate rocks of Paleozoic age underlie the Tertiary volcanic rocks. The geology and description of stratigraphic units in the study area have been defined by Winograd and Thordarson (1975), Byers and others (1976), Carr and others (1986), and Carr (1988). The nomenclature for stratigraphic units in the study area was revised by Sawyer and others (1994), and this report uses the revised geologic nomenclature.

This report describes the equipment and methods used during 1996 to collect and process water-level data, presents the 1996 data, and lists 1996 water-level altitudes for a network of 24 wells (fig. 1, table 1). The waterlevel network during 1996 included 22 wells representing 28 depth intervals that were monitored periodically by means of manual measurements, and 2 wells representing 3 depth intervals that were monitored hourly and periodically. Continuous water-level and fiuid-pressure data were also collected at well USW H-5 to allow monitoring 


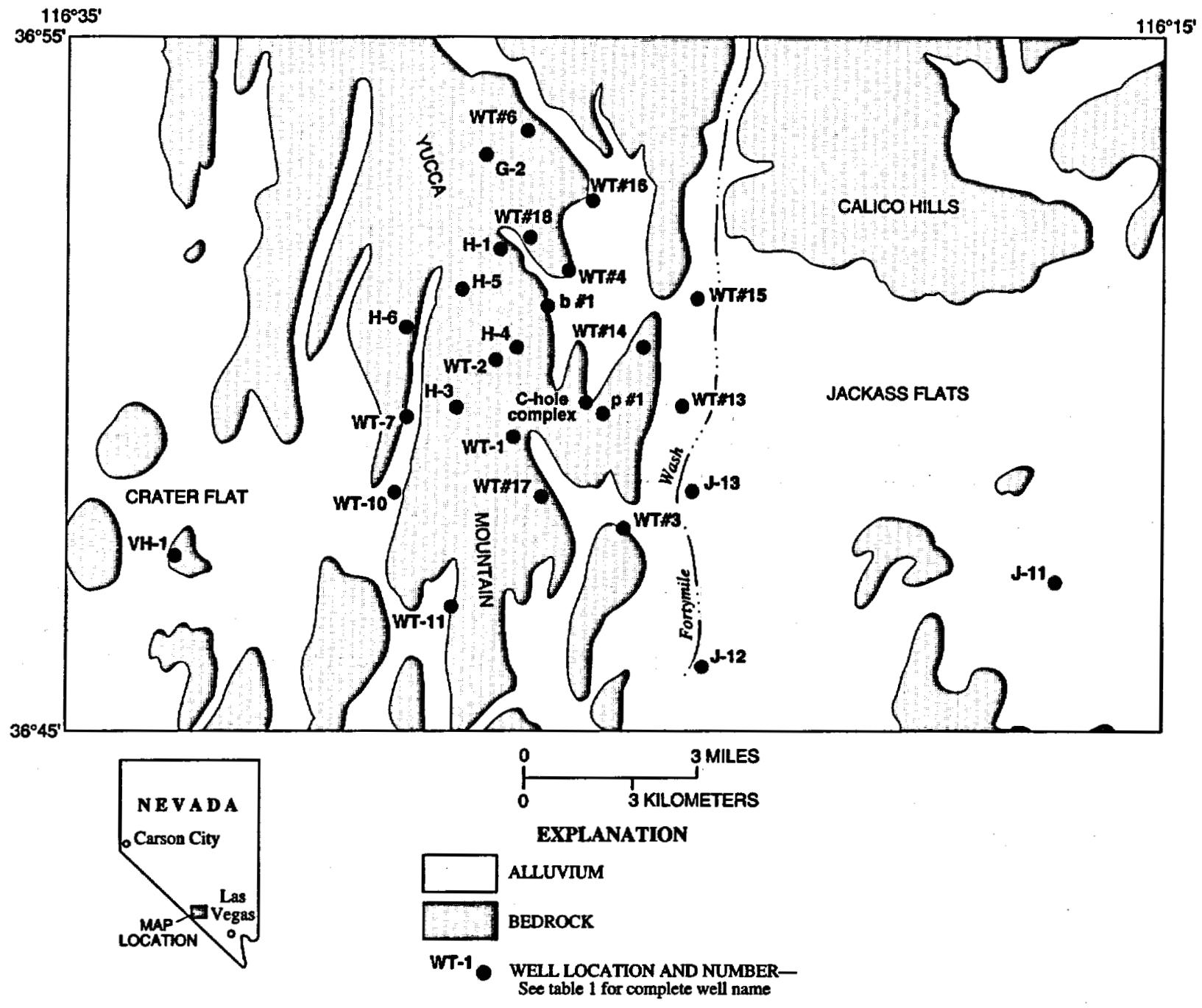

Figure 1. Location of Yucca Mountain area and location of wells.

of possible water-level fluctuations caused by earthquakes; however, these continuous data are not included in this report. All wells monitor water levels in the various Tertiary-age volcanic rocks that underlie the Yucca Mountain area except well UE-25 p\#1, which monitors water levels in the Paleozoic carbonate rocks that underlie the volcanic rocks.

The two wells that were being monitored hourly for the water-level network had the data-collection equipment removed during August and September 1996, and hourly monitoring of water levels, in support of the waterlevel network, was discontinued. ${ }^{1}$ Also, with the removal of the data-collection equipment, monitoring for possible water-level fluctuations caused by earthquakes was discontinued.

\footnotetext{
${ }^{1}$ Continuous collection of water-level data did occur beyond September 1996 in support of hydraulic testing at the C-hole complex and at well USW G-2.
} 
Table 1. Summary of wells monitored for water levels, 1996

[p \& h, well measured periodically and hourly during 1996; p, well measured periodically during 1996; --, data not available]

\begin{tabular}{|c|c|c|c|c|c|c|}
\hline \multirow[b]{2}{*}{ Well name } & \multirow[b]{2}{*}{$\begin{array}{l}\text { Approximate } \\
\text { drilled depth } \\
\text { (meters) }\end{array}$} & \multirow[b]{2}{*}{$\begin{array}{l}\text { Approximate depth } \\
\text { below land surface } \\
\text { of bottom of moni- } \\
\text { toring tube } \\
\text { (meters) }\end{array}$} & \multirow[b]{2}{*}{$\begin{array}{l}\text { Date completed } \\
\text { (month/year) }\end{array}$} & \multicolumn{3}{|c|}{ Water level } \\
\hline & & & & $\begin{array}{c}\text { Approximate } \\
\text { mean, 1996, depth } \\
\text { below reference } \\
\text { point } \\
\text { (meters) }\end{array}$ & $\begin{array}{l}\text { Approximate } \\
\text { mean, 1996, } \\
\text { altitude } \\
\text { (meters) }\end{array}$ & $\begin{array}{l}\text { Frequency } \\
\text { monitored }\end{array}$ \\
\hline USW WT-1 & डा5 & 507.5 & $3 / 83$ & 471 & 730 & $\overline{\mathbf{p}}$ \\
\hline USW WT-2 & 628 & 622.0 & $7 / 83$ & 571 & 731 & p \\
\hline UE-25 WT\#3 & 348 & 343.0 & $5 / 83$ & 300 & 730 & p \\
\hline UE-25 WT\#4 & 482 & 477.6 & $6 / 83$ & 439 & 731 & p \\
\hline UE-25 WT\#6 & 383 & 372.0 & $6 / 83$ & 280 & 1,035 & p \\
\hline USW WT-7 & 491 & 481.3 & $7 / 83$ & 421 & 776 & p \\
\hline USW WT-10 & 431 & 402.6 & $8 / 83$ & 347 & 776 & $\mathbf{p}$ \\
\hline USW WT-11 & 441 & 416.0 & $8 / 83$ & 364 & 731 & p \\
\hline UE-25 WTH13 & 354 & 346.0 & $7 / 83$ & 303 & 729 & p \\
\hline UE-25 WT\#14 & 399 & 397.2 & 9/83 & 346 & 730 & p \\
\hline UE-25 WT\#15 & 415 & 406.9 & $11 / 83$ & 354 & 729 & $\mathbf{p}$ \\
\hline UE-25 WT\#16 & 521 & 514.0 & $11 / 83$ & 472 & 738 & p \\
\hline UE-25 b\#1 & 1,220 & $\ldots$ & 9/81 & -.. & $\ldots$ & - \\
\hline upper interval & -- & 488.0 & - & 470 & 730 & $\mathbf{p}$ \\
\hline UE-25 p\#1 & 1,805 & $t^{\prime} 418.0$ & $5 / 83$ & 362 & 753 & $\mathrm{p} \& \mathrm{~h}$ \\
\hline USW VH-1 & 762 & 205.4 & $2 / 81$ & 184 & 779 & $\mathbf{p}$ \\
\hline USW G-2 & 1,831 & 2597.0 & $10 / 81$ & 535 & 1,018 & p \\
\hline USW H-1 & 1,829 & $\ldots$ & $1 / 81$ & $\ldots$ & -.- & $\ldots$ \\
\hline Tube 1 & -.. & $1,806.0$ & - & 517 & 786 & $\mathbf{p}$ \\
\hline Tube 2 & - & $1,115.0$ & - & 568 & 736 & p \\
\hline Tube 3 & $\ldots$ & 741.0 & - & 572 & 731 & p \\
\hline Tube 4 & $\cdots$ & 640.0 & $\cdots$ & 572 & 731 & p \\
\hline USW H-3 & 1,219 & $\ldots$ & $3 / 82$ & $\ldots$ & - & - \\
\hline upper interval & - & 762.0 & - & 752 & 731 & p \\
\hline lower interval & -- & $1,114.0$ & - & 723 & 760 & p \\
\hline USW H-4 & 1,219 & $\ldots$ & $6 / 82$ & -- & $\ldots$ & $\ldots$ \\
\hline upper interval & - & 525.0 & - & 518 & 730 & $\mathbf{p}$ \\
\hline lower interval & - & $1,188.0$ & - & 518 & 730 & p \\
\hline USW H-5 & 1,219 & - & $8 / 82$ & - & - & - \\
\hline upper interval & - & 709.0 & $\ldots$ & 703 & 775 & p\&h \\
\hline lower interval & - & 846.0 & --. & 703 & 776 & p\&h \\
\hline USW H-6 & 1,220 & $\ldots$ & $10 / 82$ & -- & $\ldots$ & - \\
\hline upper interval & - & 533.0 & $\ldots$ & 526 & 776 & $\mathbf{p}$ \\
\hline lower interval & - & 752.0 & - & 526 & 776 & p \\
\hline UE-25 J-11 & 405 & (3) & $7 / 57$ & 317 & 732 & $\mathbf{p}$ \\
\hline UE-25 J-12 & 4347 & - & $8 / 68$ & 227 & 728 & p \\
\hline UE-25 J-13 & 1,063 & - & $1 / 63$ & 283 & 728 & p \\
\hline
\end{tabular}

'Well is constructed so that the hydraulic head in the Paleozoic carbonate rocks located 1,244 meters below land surface is monitored.

${ }^{2}$ Before October 1, 1995, well measured through open casing. Well is open hole from 242 meters below land surface to the bottom of the well. After October 1, 1995, well monitored through monitoring tube which was placed to a depth of 597.0 meters.

${ }^{3}$ Well measured through open casing. Well is cased to bottom of well. Casing is perforated from 328.3 to 334.4 meters below land surface and from 379.2 to 396.2 meters below land surface.

${ }^{4}$ Original drilled depth 271 meters in 1957; well deepened to present depth in 1968. 
Water-level data are presented as hydrographs of water-level altitudes for each well. Data sets for the wells measured continuously and periodically include both daily mean water levels of the continuous data and manual water-level measurements. Data sets for wells measured periodically are only manually measured water levels. The hourly water levels were collected using pressure sensors and electronic data loggers. The pressure data were converted to water-level altitude using manual measurements of the water level. The periodic manual measurements were made using calibrated steel tapes.

This report is a companion and supplement to other reports that present water levels in the Yucca Mountain area (Robison and others, 1988; Gemmell, 1990; O'Brien, 1991; Boucher, 1994b; Luckey and others, 1993; Lobmeyer and others, 1995; Tucci, O'Brien, and Burkhardt, 1996; O'Brien and others, 1995; Tucci, Goemaat, and Burkhardt, 1996; Graves and others, 1996; Graves and others, 1997; and Graves and Goemaat, 1998). Robison and others (1988) describe the details of how the manual water-level measurements were made and corrected to compute the water-level altitude. Graves and others (1997) present a synthesis of water-level data collected from 1985 through 1995.

The water-level data were obtained as part of the Yucca Mountain Project of the U.S. Department of Energy. The Yucca Mountain Project is described by a Site Characterization Plan (U.S. Department of Energy, 1988). The data in this study were collected by the U.S. Geological Survey and its contractors in cooperation with the U.S. Department of Energy under Interagency Agreement DE-AI08-92NV10874.

\section{WELL DESIGNATIONS}

Each well used in the study of the Yucca Mountain area has a unique name or number. Wells on the Nevada Test Site (NTS) use an NTS designation, whereas wells off the NTS use a slightly different designation. Wells on the NTS begin with UE (for Underground Exploratory), followed by the NTS area number (always 25 in this report). This designation-UE-25-commonly is followed by one or more letters signifying the purpose of the well or simply by a sequential letter, followed by a sequence number. Wells off the NTS begin with the letters USW (for Underground, Southern Nevada, Waste). The designation-USW-is followed by one or more letters signifying the primary purpose of the well followed by a sequence number. The letters signifying purpose that are used in this report are $\mathrm{G}$ (collection of geologic data), $\mathrm{H}$ (collection of hydrologic data), $\mathrm{P}$ (collection of data on rocks of Paleozoic age), VH (collection of hydrologic and geologic data on volcanic rocks) and WT (collection of water-table data).

Nevada State Coordinates are used to identify the location of wells cited in this report. These coordinates are for the central zone of Nevada and are based on a Transverse Mercator projection. The origin of this projection for the central zone of Nevada is latitude $34^{\circ} 45^{\prime} \mathrm{N}$., and the central meridian is at longitude $116^{\circ} 40^{\prime} \mathrm{W}$. The Nevada State Coordinates are in meters north of the baseline and in meters, plus 152,400 east of the central meridian. The Nevada State Coordinate locations for the wells were determined by Holmes \& Narver, Inc., contractor to the U.S. Department of Energy for surveying at the NTS and Yucca Mountain area. Latitude and longitude values of the wells were calculated from the Nevada State Coordinates.

Each well has a Site ID number which is used as a unique identification number of the well in the U.S. Geological Survey's National Water Information System data base. The Site ID is generated by combining the original designations of the latitude and longitude with a two-digit sequence number. The Site ID is for convenience of identification only and should not be used as an actual location number because the original designations of latitude and longitude may be inaccurate. Even if original values of the latitude and longitude are revised later, the Site ID for the well is not changed. If more than one well exists within the 1-second rectangle of latitude and longitude, the two-digit sequence number ensures uniqueness of the Site ID.

Some wells within the water-level network have had packers or piezometers installed so the water level at discrete depth intervals can be measured. In these instances, before the packers or piezometers were installed, the well was assigned one Site ID (generally with a sequence number of 01), and, prior to 1990 , each depth interval was assigned its own unique Site ID by incrementing the sequence number. Hence, some wells within the network 
have several Site ID's. However, since 1990, the water-level data are generally stored in the National Water Information System data base under the Site ID with sequence number 01. Exceptions are wells USW H-5 and UE-25 p\#1, which use the Site ID with sequence number 02. For those wells that have more than one zone monitored, the water levels are kept distinct in NWIS with the use of data descriptors that define each unique zone.

\section{DATA-COLLECTION SYSTEM}

Water-level data are collected at Yucca Mountain by means of manual measurements, collected periodically, and pressure sensors, which are monitored hourly by data loggers. The manual measurements are discussed first, followed by a discussion of the pressure-sensor system. All water-level measurements are subject to various corrections, and these corrections also are discussed.

\section{Periodic Measurements}

Periodic, manual, water-level measurements at wells require visits by trained personnel, who perform specific operations and record the results. Operational plans for 1996 called for measurements at least every 4 months (once a quarter). However, most wells were measured more frequently with monthly measurements made during the third and fourth quarters of 1996. Manual water-level measurements also were made at hourly monitored wells at times of calibration or replacement of defective pressure sensors.

Periodic measurements during 1996 were made primarily with Chain \#3, which is a specially constructed reeled steel tape that is $7.9 \mathrm{~mm}$ wide and $792 \mathrm{~m}$ long. Measurements were also made with the 2,800-foot reference steel tape, a reeled steel tape that is $6.4 \mathrm{~mm}$ wide and $853 \mathrm{~m}$ long. Detailed descriptions of the 2,800-foot reference steel tape are given by O'Brien (1991) and are not repeated here. O'Brien (1991) also describes Chain \#2 (not used to measure water levels during 1996). Because of the similarities between Chain $\# 2$ and Chain $\# 3$, the detailed description of Chain $\# 2$ given by O'Brien (1991) is considered to be the same for Chain \#3 and is not repeated here.

\section{Correctlons and Adjustments to Manual Measurements}

Various factors affect the accuracy of manual water-level measurements and are considered in the process of determining an accurate depth below land surface and water-level altitude. All measurements in this report have been corrected to obtain the most accurate water-level altitudes. The correction factors applied to steel-tape measurements for each well are summarized in table 2.

Corrections made for steel-tape water-level measurements include mechanical stretch and thermal expansion of the tape. All measurements, except those at wells UE-25 J-11, UE-25 J-12, and UE-25 J-13, are corrected for borehole deviation from vertical. Borehole-deviation information is not available for wells UE-25 J-11, UE-25 J-12, and UE-25 J-13. All measurements are referenced to sea-level datum.

\section{Mechanical Stretch Correction}

Mechanical stretch is associated with the weight of the suspended steel tape and attached plumb bob (Garber and Koopman, 1968; Robison and others, 1988). The calculated adjustment for the steel tapes used 


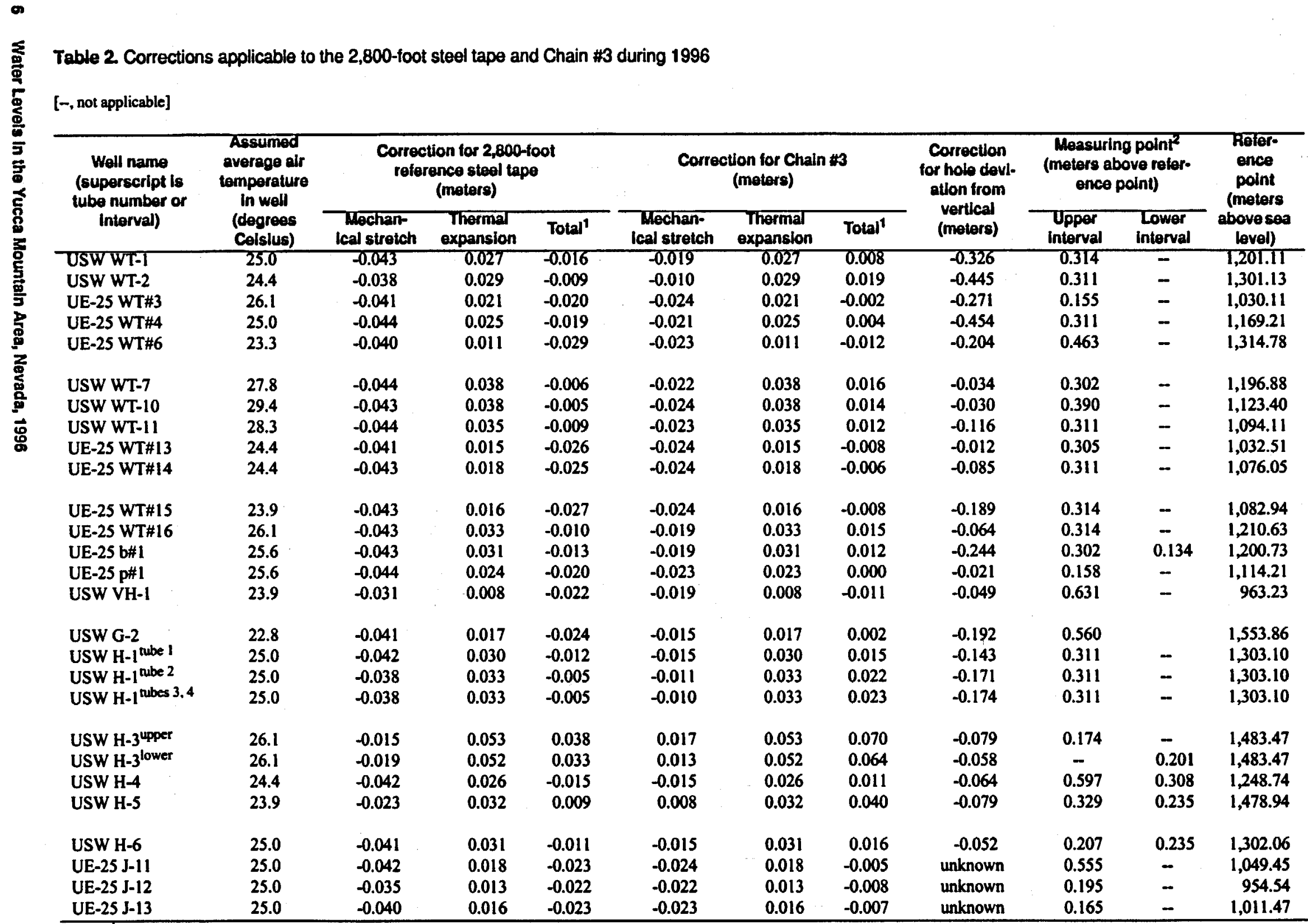

${ }^{\mathrm{I}}$ Total correction may not equal sum of mechanical stretch and thermal expansion due to rounding.

${ }^{2}$ Wells with only one interval have measuring point listed as upper. 
during 1996, based on stretch coefficients and an approximate weight of $0.45 \mathrm{~kg}$ for the plumb bob used with Chain \#3 and the 2,800-foot reference steel tape, ranged from -0.044 to $+0.017 \mathrm{~m}$ (table 2) for water levels measured in the vicinity of Yucca Mountain.

The correction for mechanical stretch of the tape is given by:

$$
\mathrm{C}=\left(\mathrm{L}^{2} \mathrm{WS}\right) / 2+\mathrm{PLS}-\mathrm{KLS}
$$

where

C is the correction, in meters;

$L$ is the apparent length of tape, in meters;

$\mathrm{W}$ is the unit weight of the tape, in kilograms per meter;

$S$ is the stretch coefficient, in meters per (meter kilogram);

$P$ is the weight of the plumb bob, in kilograms; and

$K$ is reference tension during manufacture, in kilograms.

The apparent length of tape $(\mathrm{L})$ corresponds to the depth to water in each well. Values for W were determined at a calibration laboratory at the NTS, and values for S were determined by the U.S. Geological Survey and are estimated to be accurate to 7 percent (R.R. Luckey, U.S. Geological Survey, oral commun., 1993). Values for the reference tension (K) are provided by the manufacturer at the time of purchase.

\section{Thermal Expansion Correction}

Thermal expansion of a steel tape occurs because of temperature changes. The calculated correction for thermal expansion for steel tapes is based on manufacturer specifications for thermal-expansion coefficients and on average hole temperatures calculated from temperature profiles in wells at Yucca Mountain (Garber and Koopman, 1968; Sass and Lachenbruch, 1982). The correction ranges from +0.008 to $+0.053 \mathrm{~m}$ (table 2).

Correction for thermal expansion of the tape is given by:

$$
E=(D-R) T L,
$$

where

E is the correction, in meters;

D is the assumed average air temperature in the well, in degrees Celsius;

$\mathbf{R}$ is the reference temperature during manufacture, in degrees Celsius;

$\mathbf{T}$ is the thermal expansion coefficient, in meters per meter-degree Celsius; and

$L$ is the apparent length of the tape, in meters.

Equation 2 differs from that of Garber and Koopman (1968, p. 4). The correction for thermal expansion in their report was subtracted from the measured depth to water when it should have been added (J.H. Robison, U.S. Geological Survey, written commun., 1985).

The tape corrections, which include mechanical stretch and thermal expansion, and average air temperature in the well, are given in table 2. Approximate depth to water is analogous to apparent length of the tape, $\mathrm{L}$, in equations 1 and 2 . The tape-dependent variables for equations 1 and 2 are defined for each tape in table 3. 
Table 3. Mechanical stretch and thermal expansion equation variable values for the 2,800 -foot reference steel tape and Chain \#3.

\begin{tabular}{lcl}
\hline \multicolumn{1}{c}{ Varlable } & $\begin{array}{c}2,800-\text {-foot } \\
\text { reference steel tape }\end{array}$ & Chain \#3 \\
\hline Unit weight of the tape, W (kilogram/meter) & $2.08 \times 10^{-2}$ & $2.65 \times 10^{-2}$ \\
Stretch coefficient, S [meter/(meter kilogram)] & $2.48 \times 10^{-5}$ & $1.69 \times 10^{-5}$ \\
Weight of plumb bob, P (kilogram) & 0.45 & 0.45 \\
Reference tension during manufacture, X (kilogram) & 9.07 & 9.07 \\
Reference temperature during manufacture, R (degree Celsius) & 20 & 20 \\
Thermal expansion coefficient, T [meter/(meter degree Celsius)] & $1.16 \times 10^{-5}$ & $1.16 \times 10^{-5}$ \\
\hline
\end{tabular}

Borehole-Deviation Correction

In addition to the corrections for mechanical stretch and thermal expansion, corrections must also be made for boreholes that are not vertical (borehole deviation). Gyroscopic surveys were made in all measured wells except wells UE-25 J-11, UE-25 J-12, and UE-25 J-13. The gyroscopic surveys measured borehole deviation from vertical. The difference between measured depth and true vertical depth is the borehole deviation, or borehole correction. Corrections range from -0.012 to $-0.454 \mathrm{~m}$ (table 2). Corrections generally increase with increasing well depth.

\section{Water-Level Altitudes}

Water-level altitudes are calculated by subtracting the corrected depth to water from the altitude of the reference point. The reference point generally is a metal tag on the well casing located at or near land surface. The measuring point for the wells, at the top of the access tube, is at some distance above the reference point, and the height of the measuring point is subtracted from the apparent depth to water as part of the process to calculate the corrected depth to water. Reference-point and measuring-point values for all wells are listed in table 2 and are described in the individual well sections. Water-level altitudes in this report generally are based on a survey of the water-level monitoring network reference points made in late 1984 by the U.S. Geological Survey National Mapping Division (Merle E. Southern, U.S. Geological Survey, written commun., 1985).

\section{Example Calculatlons}

An example measurement for well USW WT-1 for February 21, 1996, is presented to illustrate a calculation made to derive the altitude of the water level with a steel tape. The units of measurement for a steel tape are feet. All water-level measurements are recorded to the nearest 0.01 foot and later converted to meters. The calculated altitude is the value reported in the section "Well Data and Water Levels."

At least two measurements of the water level are made and averaged during each visit to the well, and the appropriate corrections are applied after averaging the water-level measurements. Additional measurements are made only if the two measured depths differ by more than 1 part in 10,000 for measurements of more than 1,000 feet, or more than 0.1 foot for measurements less than 1,000 feet. 


\section{Example A: Chain \#3}

The water-level measurement on February 21, 1996, at USW WT-1 was made with Chain \#3. The HELD is the indicated footage on the tape when it is held at the measuring point during a measurement, and CUT is the footage of tape that is wetted during its submersion in the water. The difference between HELD and CUT is the apparent depth to water below the measuring point.

The measurements and corrections for USW WT-1 on February 21, 1996, were:

\begin{tabular}{|c|c|c|c|}
\hline Reading & $\begin{array}{c}\text { Measurement } \\
1\end{array}$ & $\begin{array}{l}\text { Measurement } \\
2\end{array}$ & \\
\hline HELD (ft) & $1,549.00$ & $1,550.00$ & \\
\hline CUT (ft) & -2.28 & -3.26 & \\
\hline Apparent depth to water (ft) & $1,546.72$ & $1,546.74$ & \\
\hline Average of two apparent depths to water ( $\mathrm{ft}$ ) & & & $1,546.73$ \\
\hline $\begin{array}{l}\text { Apparent depth to water }(1,874.26 \mathrm{ft} \times 0.3048 \text { meter per } \\
\text { foot })(\mathrm{m})\end{array}$ & & & 471.44 \\
\hline Measuring point (m) (table 2) & & & -0.314 \\
\hline Tape correction (m) (table 2) & & & +0.008 \\
\hline Correction for borehole deviation from vertical (m) (table 2) & & & -0.326 \\
\hline Corrected depth below reference point (m) & & & 470.81 \\
\hline \multicolumn{4}{|l|}{ Determination of water-level altitude: } \\
\hline Altitude of reference point (m) (table 2) & & & $1,201.11$ \\
\hline Corrected depth (m) & & & -470.81 \\
\hline Altitude of water level (m) & & & $\mathbf{7 3 0 . 3 0}$ \\
\hline
\end{tabular}

\section{Precision and Accuracy}

An analysis of precision and accuracy of field data was conducted for manual water-level measurements, which included all periodic measurements obtained during 1988-90 (Boucher, 1994a). The mean precision range of the 2,800-foot reference steel tape, based on 31 measurements, was $0.026 \mathrm{ft}$ (because of changes in accuracy due to conversion to metric units and rounding of conversions, this discussion of precision and accuracy is in the units of the referenced report). The precision of Chain \#3 is not known but is believed to be the same or nearly the same as that of Chain \#2, because each chain has nearly the same physical characteristics and because they were identically constructed. The mean precision range of Chain \#2, based on 341 measurements, was $0.014 \mathrm{ft}$. Ninety-seven percent of all measurements obtained with the steel tapes were precise to within $0.05 \mathrm{ft}$ during 1988-90.

The overall accuracy of the computed water-level altitude depends on the individual accuracies of its computational components such as: (1) water-level measurement, (2) borehole correction, (3) height of the measuring point, (4) altitude of the reference point, and (5) the precision of the 2,800-foot reference steel tape. The total accuracy of measurements taken with the steel tapes during 1988-90 was estimated to be $0.36 \mathrm{ft}$, neglecting the accuracy of the borehole correction factors (Boucher, 1994a). Accuracy of the borehole correction factors is indeterminate because documentation of the boreholedeviation surveys was inadequate to assess their accuracy and because no borehole-deviation data are available for wells UE-25 J-11, UE-25 J-12, and UE-25 J-13. The unknown accuracy of the borehole corrections poses a problem in the calculation of overall accuracy values. 


\section{Hourly Measurements}

Hourly water-level measurements require that equipment be installed in the well to record water levels. Trained personnel install the equipment in the well, periodically calibrate equipment or replace it as necessary, and periodically retrieve the data from the site.

Hourly measurements are of a sufficient frequency that water-level fluctuations are adequately defined to evaluate daily or longer term trends. Hourly measurements are not sufficient, however, to detect short-term waterlevel fluctuations, such as those induced by earthquakes (O'Brien, 1992 and 1993). Hourly measurements were stored and later retrieved from data loggers at each site. Continuous measurements were collected at well USW H-5 in 1996 to monitor water-level and fluid-pressure response to earthquakes; however, these continuous data are not included in this report.

Pressure sensors and data loggers are used to measure water-level fluctuations. Because of the large depths to water (up to $752 \mathrm{~m}$ ), traditional water-level-sensing methods, such as float-cable-pulley system, water-seeking device, and bubble tube, are not feasible. However, electronic signals from a submerged pressure sensors are relatively easy to transmit through a multiconductor suspension cable to a recording device accessible to personnel on the surface. Electronic data loggers at the surface are used to control, measure, and store data from the pressure sensors.

\section{Equipment}

The hourly water-level network equipment consists of a pressure sensor, which senses depth of submergence, a wireline cable to transmit a signal between the pressure sensor and the surface, and a data logger to control the system, measure the pressure sensor output, and store the data. An external 12-volt battery provides power to the system, and a solar panel charges the battery.

The wireline cable, consisting of four conductors, appropriate insulation, and two external wire wraps (for strength and stability), is used to transmit a signal between the data logger at the surface and the downhole pressure sensor. The required length of wireline cable to monitor a typical well at Yucca Mountain weighs several tens of kilograms, so power equipment is used to install and calibrate the system.

The water-level monitoring systems are scheduled for calibration approximately every 4 months, and the calibration includes a water-level measurement. The water-level measurements are made using either the pressure sensor or a calibrated steel tape. The water-level measurements, after adjustments, result in altitudes of water surface at the time of calibration.

\section{Transducers}

Historically, the pressure sensors used in the wells of the water-level network to monitor hourly water-level fluctuations were pressure transducers or pressure transmitters. Pressure transducers and transmitters are pressure sensors that convert a change in a mechanical quantity (such as pressure) into a change in an electrical quantity (such as resistance). These sensors are used to measure pressure and are capable of being immersed in water to measure the depth of submersion. Because the sensors remains at a fixed depth in the well, water-level fluctuations are equivalent to changes in the depth of submersion detected by the sensors.

The pressure-sensing components of a pressure sensor consist of a strain gage to convert pressure into electrical resistance and a Wheatstone bridge to allow measurement of the change in resistance. The major difference between pressure transducers and pressure transmitters is in the form of the input and output. Pressure transducers use voltage as input and output, whereas pressure transmitters use current as input and output. Pressure transmitters are constructed with the same strain gage and Wheatstone bridge arrangement as a pressure transducer; however, the current input is converted to voltage by an amplifier before it enters the strain gage and the voltage is 
converted back to current by a regulator after it passes through the Wheatstone bridge. The required wiring of pressure transducers and transmitters to a data logger differ, because the data loggers measure voltage and not current. The output signal of a pressure transducer is in voltage and can be entered directly into the data loggers, but the output signal of a transmitter must be connected to a resistance load, and then the voltage drop across the load is measured by the data logger. Pressure transducers are simpler and do not require signal conversions; however, they are prone to stray electrical forces that can be amplified by the long wireline cable. As a result, pressure transmitters have been found to be more reliable for measuring water levels at Yucca Mountain. Regardless of which type of pressure sensor is used, the pressure sensor output increases as the depth of submergence increases.

In previous water-level reports, the term "transducer" referred to either a pressure transducer or pressure transmitter. In the wells monitored hourly in 1996 only pressure transmitters were used to measure water-level fluctuations. However, to maintain consistency between this report and previously published water-level reports, the term "transducer" will be used for the remainder of this report to describe the pressure sensors used to monitor water-level fluctuation.

Transducers are made for a range of pressures. Generally, the smaller the pressure range of the transducer, the more accurately pressure changes and water-level fluctuations can be measured. Transducer pressure ranges used in the hourly water-level network for 1996 ranged from 5 psi (pounds per square inch) (used in wells UE-25 p\#1 and USW H-5, upper interval) to 20 psi (used in well USW H-5, lower interval).

The water-level network for 1996 used only gage transducers. A gage transducer measures pressure relative to atmospheric pressure and has a vent tube from the reference side of the strain gage to a point above the water surface. Gage transducers are preferable in the water-level network because only water-level fluctuations (and not air-pressure changes) affect the transducer output.

As a part of the calibration process, a water-level measurement must be obtained by either a manual measurement, using a calibrated steel tape, or by "tagging" the water level using the transducer. Tagging the water level is done by raising the transducer until it comes in contact with the water surface in the well. The difference in the depth to water from the last manual measurement, indicated by a tape mark on the transducer cable, is then noted in the log book as part of the calibration record. If the transducer is functioning properly, the water level obtained by tagging should be as accurate as a manual measurement; however, if the transducer is not functioning properly, errors in the measured water level (probably less than $0.1 \mathrm{~m}$ ) are possible.

The transducers are calibrated when installed in the well, when removed from the well (if possible), and approximately every 4 months while in service in the well (reduction in manpower in the water-level program during 1996 prevented 4-month calibrations; transducers were calibrated every 5 to 6 months during 1996). The calibration consists of manually raising or lowering the transducer in increments and noting the change in transducer output. The data logger (described in the next section) is used in the calibration to provide the applied voltage, if necessary, and to measure the output signal, so the calibration is for the entire transducer/data-logger system and not only for the transducer.

On June 4, 1996, the transducer/data-logger system at well USW H-5, upper interval, was calibrated. The calibration started with the transducer submerged $2.44 \mathrm{~m}$ below the water surface. The following values were obtained: 


\begin{tabular}{|cc|}
\hline $\begin{array}{c}\text { Depth of submergence } \\
\text { below water surface } \\
\text { (meters) }\end{array}$ & $\begin{array}{c}\text { Average transducer output } \\
\text { (millivolts) }\end{array}$ \\
\hline 2.44 & 37.07 \\
2.13 & 33.68 \\
2.07 & 32.98 \\
2.01 & 32.30 \\
1.95 & 31.61 \\
1.89 & 30.92 \\
1.83 & 30.22 \\
1.77 & 29.55 \\
1.71 & 28.86 \\
1.65 & 28.16 \\
1.58 & 27.47 \\
1.52 & 26.79 \\
1.22 & 23.34 \\
0.91 & 19.88 \\
0.61 & 16.42 \\
0.30 & 12.98 \\
\hline
\end{tabular}

The transducer output is the average of three readings taken after the transducer output has stabilized. A regression analysis was performed on the calibration data, excluding any points where the transducer was not submerged. The slope of the regression line for well USW H-5, upper interval, on June 4, 1996, was 0.088 meter per millivolt with a coefficient of determination $\left(r^{2}\right)$ of 1.000 . The slope of the regression line, the transducer output at the set point (the point at which the transducer is set after calibration), and the water-level measurement at the time of calibration were used to convert transducer output to water-level altitude. The set point for well USW H-5, upper interval, on June 4, 1996, was $1.83 \mathrm{~m}$.

\section{Data Loggers}

Data-collection platforms (DCP's) that collect, store, and transmit data to a satellite from which the data are relayed to a ground station were used as the data logger for the data-acquisition system of the hourly water-level network during 1996. Data are collected and stored hourly in a DCP and transmitted every 4 hours to a Geostationary Operational Environmental Satellite (GOES). The data are then relayed to a Direct Readout Ground Station and stored in USGS computers for evaluation and further processing. Details of DCP use and operation and GOES systems are described by Blee and others (1986).

In addition to transducer output, the DCP data loggers also read information such as battery voltage, excitation voltage, and the panel temperature of the data loggers. These variables are important in evaluation of the reliability of the system and are also transmitted with the transducer data. All internally stored data in the DCP are periodically transferred to computer diskettes using a portable computer. These data files are used as backups to the transmitted data and are used to fill in data gaps that may occur due to any malfunctions in the transmission or receiving process. 


\section{Processing and Adjustments}

The data stored in the DCP data loggers and transferred to computers are not water-level data but rather transducer output, in millivolts. The transducer output are converted to water levels, as explained in the following section, "Conversion to Water-Level Altitude." The water-levels are then evaluated. Anomalous data points, such as those produced during transducer calibrations, by random electronic signals, or due to instrument malfunction are not converted to water levels.

\section{Conversion to Water-Level Altitude}

In an ideal circumstance, a transducer would be calibrated several times during its operating life, its output would be free of drift, and its characteristics would not change with time. However, this ideal situation rarely occurred, causing the transducer output conversion to be more difficult. As a result, some of the transducer output and resulting converted water levels were not considered reliable.

Converted water levels were evaluated for data reliability. The data were examined at a time scale that clearly showed the hourly and daily fluctuations so that the validity of the data could be determined. The data were compared to barometric-pressure data, earth-tide potential data, and other periods of record for the same site and depth interval. If the data were independently validated, the data were retained and included in this report. If the data were not validated independently, the data were given indeterminate status and are not included in this report.

The equation for converting transducer output to water-level altitude under ideal conditions is:

$$
W=W_{c}+\left(T-T_{c}\right) S_{c}
$$

where

$\mathrm{W}$ is the water-level altitude, in meters;

$\mathbf{W}_{\mathbf{c}}$ is the water-level altitude at calibration, in meters;

$T$ is the transducer output, in millivolts;

$T_{c}$ is the transducer output at set point following calibration, in millivolts; and

$S_{c}$ is the slope of the regression line, in meters per millivolt.

Equation 3 is from O'Brien and others (1995).

The following example calculation from well USW H-5, upper interval, illustrates how transducer data was converted to water levels. The water-level altitude for the calibration on June 4, 1996, was $775.44 \mathrm{~m}$ (based on a manual water level made with Chain \#3). The calibration indicated that a 0.088- $\mathrm{m}$ change in water level would cause the transducer output to change by approximately 1 millivolt. The transducer output at the post-calibration set point $(1.83 \mathrm{~m}$ below water surface) was 30.22 millivolts. The transducer output at 15:00 on June 9, 1996, was 30.63 millivolts. To summarize, equation 3 variables are:

$$
\begin{aligned}
& W_{c}=775.44 \text { meters } \\
& T=30.63 \text { millivolts } \\
& T_{c}=30.22 \text { millivolts } \\
& S_{c}=0.088 \text { meter per millivolt }
\end{aligned}
$$

Given these data, the water-level calculation for 11:00 on June 9, 1996, would be as follows:

$$
W=775.44+(30.63-30.22) 0.088=775.48 \text { meters }
$$


Change in the slope of the regression line, $S_{c}$, and change in the transducer output at set point, $T_{c}$, between consecutive calibrations are types of drift corrected for in the conversion process. Although the slope of the regression line generally does not change dramatically between calibrations, it usually changes to some degree. The change in slope is assumed to be linear between calibrations. Set-point drift occurs when the expected transducer output (based on manual tags) does not match the actual measured set-point output. Set-point drift is also assumed to be linear over time.

The water-level altitude is assumed to have remained constant from the last transducer output prior to calibration through the first transducer output after calibration. This assumption probably introduces, at most, a few hundredths of a meter error in the calculation of water-level altitude. If more than one calibration was done on a transducer on the same day, the last calibration is used to calculate water-level altitude for the following period.

\section{Quality Assurance}

Water-level data for Yucca Mountain and vicinity may be used to assess the expected performance of a potential high-level nuclear-waste repository, and confidence in the reliability of the data used in such an assessment is required. A quality-assurance program has been implemented by the U.S. Geological Survey for the Yucca Mountain Project to support the reliability of the data and interpretations of the data.

\section{Onsite Procedures}

The quality-assurance program requires that water-level measurements be obtained by methods described by formal technical procedures. The technical procedures include calibrations and adjustments done during the measuring operation to ensure that the equipment is operating properly and that expected precision and accuracy are attained. For example, the procedure for measuring water-level changes with a pressure transducer specifies how to install and calibrate the transducer and how to maintain the records of the calibrations.

Data are recorded in logbooks at the well site. Data recorded include: time and date of the visit; names of operators making the visit; identification of specific equipment used; calibration data; water-level measurement data; and correction factors, if any, applied to the data at the well site. In addition, the entry in the logbooks may include comments concerning factors that may be relevant to the collected data, such as discussion of problems with equipment or weather conditions during the water-level measurement or transducer calibration.

\section{Office Processing and Revlew}

The original logbooks and field-note records were maintained throughout the calendar year at the onsite operations headquarters on the Nevada Test Site. The records were reviewed for completeness and accuracy and to ensure that proper technical procedures were followed. Any needed adjustments not done during onsite operations, such as tape and borehole-deviation corrections, are made on water-level worksheets in the operations headquarters on the Nevada Test Site. After independent data review and any needed adjustments, the logbooks and related records are transferred to a Yucca Mountain Project archive.

The transducer output is entered into a temporary computer data base and is plotted to facilitate data review and to discover any instrumentation problems. After this review, the transducer output is converted to water levels. The converted water-level data are reviewed for technical quality. In addition to being published by the U.S. Geological Survey, both the raw transducer output and the water-level altitudes are placed in permanent computer data bases, such as the Unit Values file of the National Water Information System used by the U.S. Geological Survey. Water-level altitudes obtained from manual measurements are also placed in the computer data base. 


\section{Qualified and Unqualified Data}

Data used by the Yucca Mountain Project are classified as either "qualified" or "unqualified." Qualified data are defined as data acquired or developed for the Yucca Mountain Project under a Nuclear Regulatory Commission-accepted quality-assurance plan or qualified in accordance with appropriate Yucca Mountain Project procedures. Depth-to-water measurements collected at Yucca Mountain after 1989 are obtained in accordance with approved Yucca Mountain Project quality-assurance procedures. However, measuring point altitudes and information used to calculate correction factors, such as borehole-deviation information, were obtained prior to the implementation of the accepted Yucca Mountain Project quality-assurance program in 1989. Therefore, the calculated water-level altitudes presented in this report are classified as unqualified data.

\section{WELL DATA AND WATER LEVELS}

This section contains information and data of all wells monitored as part of the Yucca Mountain water-level project during 1996. Information for each well includes source of information about the well, of which most is published information. Borehole-geophysical logs and core-measurement data for the wells are given by Nelson and others (1991). Previously collected water-level data can be found in Boucher (1994b), Gemmell (1990), Lobmeyer and others (1995), Luckey and others (1993), O'Brien (1991, 1992, and 1993), O'Brien and others (1995), Tucci, O'Brien, and Burkhardt (1996), Tucci, Goemaat, and Burkhardt (1996), Graves and others (1996), Graves and others (1997), and Graves and Goemaat (1998). Complete bibliographic citations are in the "References Cited" section. Important information about each well (location and identification, drilling and casing information, access to and description of interval for measuring water levels, and information for calculation of waterlevel altitude) are summarized in the "Well Specifications" subsection of each well. Although water-level altitudes are corrected for borehole deviation, other depth-related values in the "Well Specifications" subsection (such as casing or access-tube depths) are uncorrected, although the corrections are always less than $0.5 \mathrm{~m}$ and some are less than $0.1 \mathrm{~m}$ (table 2). Various statistical information concerning the water levels and hydrographs of water-level altitudes are also presented for each well. With the exception of well USW G-2, all hydrographs are uniformly plotted for calender year 1996 with a y-axis (water-level) span of $2.5 \mathrm{~m}$. The y-axis span for well USW G-2 was $5 \mathrm{~m}$, this is due to the drawdown and slow recovery following completion of the hydraulic testing at the well.

Additional information included for each well is specific to the frequency of data collection (periodic or hourly measurements). Because all wells were measured periodically at some time during the year, a table with the periodic measurement and method of measurement is included for each well. For wells that were measured hourly during part of the year, two additional tables are shown, one with the transducer calibration information and one with the monthly mean water levels for the months the hourly measurements were made. Calibration information includes the transducer serial number, calibration date, slope of the regression line, coefficient of determination, and the water-level altitude determined at the time of calibration. Comments concerning any special conditions or information that might affect the results of the calibrations or conversion of data to water levels are included, as well as explanations for periods of missing water-level data.

The 1996 mean water-level altitude is given and compared to the 1995 mean water-level altitude and to the 1985-95 mean water-level altitude for each well (table 4). For the wells monitored hourly during part of 1996, the monthly mean water levels of the hourly data were averaged with the periodic water levels collected after discontinuation of the hourly data collection. For the wells that were only measured periodically, the 1996 mean waterlevel altitude is calculated from all of the periodic measurements. Generally, mean water-level altitudes for 1996 were lower than 1995 mean water-level altitudes and 1985-95 mean water-level altitudes. The lower average water levels could be due to the additional ground-water pumpage that occurred in the Yucca Mountain area at the C-hole complex during 1996. 
Table 4. Comparison of 1985-95, 1995, and 1996 mean water-level altitudes for wells and well intervals monitored in the Yucca Mountain area

\begin{tabular}{|c|c|c|c|}
\hline Well name & $\begin{array}{l}\text { 1985-95 Mean water-level } \\
\text { altitude } \\
\text { (meters) }\end{array}$ & $\begin{array}{l}1995 \text { Mean water-level ald- } \\
\text { tude } \\
\text { (meters) }\end{array}$ & $\begin{array}{c}1996 \text { Mean water-level alti- } \\
\text { tude } \\
\text { (meters) }\end{array}$ \\
\hline USW WT-1 & 730.35 & 730.31 & 730.17 \\
\hline USW WT-2 & 730.65 & 730.57 & 730.52 \\
\hline UE-25 WT\#3 & 729.64 & 729.71 & 729.63 \\
\hline UE-25 WT\#4 & 730.78 & 730.80 & 730.66 \\
\hline UE-25 WT\#6 & $1,034.60$ & $1,034.48$ & $1,034.58$ \\
\hline USW WT-7 & 775.83 & 775.93 & 775.96 \\
\hline USW WT-10 & 776.00 & 776.12 & 776.11 \\
\hline USW WT-11 & 730.66 & 730.69 & 730.58 \\
\hline UE-25 WT\#13 & 729.11 & 729.18 & 729.11 \\
\hline UE-25 WT\#14 & 729.68 & 729.65 & 729.58 \\
\hline UE-25 WT\#15 & 729.22 & 729.27 & 729.18 \\
\hline UE-25 WT\#16 & 738.27 & 738.30 & 738.21 \\
\hline $\begin{array}{l}\text { UE-25 b\#1 } \\
\text { Upper interval }\end{array}$ & 730.65 & 730.61 & 730.44 \\
\hline UE-25 p\#1 & 752.44 & 752.57 & 752.65 \\
\hline USW VH-1 & 779.44 & 779.49 & 779.49 \\
\hline USW G-2 & $1,020.17$ & $1,019.74$ & DATA NOT AVAILABLE \\
\hline $\begin{array}{r}\text { USW H-1 } \\
\text { Tube } 1 \\
\text { Tube } 2 \\
\text { Tube } 3 \\
\text { Tube } 4\end{array}$ & $\begin{array}{l}785.49 \\
735.97 \\
730.60 \\
730.85\end{array}$ & $\begin{array}{l}785.97 \\
735.74 \\
730.64 \\
730.91\end{array}$ & $\begin{array}{l}786.00 \\
735.55 \\
730.61 \\
730.78\end{array}$ \\
\hline $\begin{array}{l}\text { USW H-3 } \\
\text { Upper interval } \\
\text { Lower interval }\end{array}$ & $\begin{array}{l}731.52 \\
755.91\end{array}$ & $\begin{array}{l}731.29 \\
759.23\end{array}$ & $\begin{array}{l}731.19 \\
760.07\end{array}$ \\
\hline $\begin{array}{l}\text { USW H-4 } \\
\text { Upper interval } \\
\text { Lower interval }\end{array}$ & $\begin{array}{l}730.40 \\
730.51\end{array}$ & $\begin{array}{l}730.37 \\
730.50\end{array}$ & $\begin{array}{l}730.28 \\
730.39\end{array}$ \\
\hline $\begin{array}{l}\text { USW H-5 } \\
\text { Upper interval } \\
\text { Lower interval }\end{array}$ & $\begin{array}{l}775.46 \\
775.62\end{array}$ & $\begin{array}{l}775.40 \\
775.78\end{array}$ & $\begin{array}{l}775.46 \\
775.65\end{array}$ \\
\hline $\begin{array}{l}\text { USW H-6 } \\
\text { Upper interval } \\
\text { Lower interval }\end{array}$ & $\begin{array}{l}776.02 \\
775.94\end{array}$ & $\begin{array}{l}776.13 \\
776.01\end{array}$ & $\begin{array}{l}776.12 \\
776.00\end{array}$ \\
\hline UE-25 J-11 & 732.21 & 732.25 & 732.25 \\
\hline UE-25 J-12 & 727.93 & 727.90 & 727.86 \\
\hline UE-25 J-13 & 728.44 & 728.43 & 728.36 \\
\hline
\end{tabular}


During 1996, water levels in the Yucca Mountain area could have been affected by long-term pumping at the C-hole complex (fig. 1) which began on May 8, 1996, and continued until November 12, 1997. Through December 31, 1996, approximately 196 million liters were pumped from well UE-25 c\#3 at the C-hole complex (M.J. Umari, U.S. Geological Survey, written commun., 1998). Wells which had the most distinct decline in water levels that are believed to be due to the C-hole complex pumpage are USW WT-1, UE-25 WT\#4, UE-25 WT\#14, UE-25 b\#1, upper interval, and USW H-4, upper and lower intervals. Other wells where water-level declines were not as great, but which are believed also to be affected by the $C$-hole complex pumpage, are UE-25 WT\#3, USW WT-11, and UE-25 WT\#15. A detailed discussion of drawdown in the Yucca Mountain area due to the 1996 and 1997 pumpage at the $C$-hole complex will be presented in a later report.

Other ground-water pumpage in the Yucca Mountain area includes annual pumpage from water-supply wells UE-25 J-12 and UE-25 J-13 of approximately 163 and 105 million liters, respectively (R.A. LaCamera, U.S. Geological Survey, written commun., 1998), and pumpage from well USW G-2 for hydraulic testing during February and April 1996 of approximately 6 million liters (G.M. O'Brien, U.S. Geological Survey, written commun., 1998). Water-level declines due to pumpage at well USW G-2 were not observed in nearby wells. Wells UE-25 J-12 and UE-25 J-13 were drilled and completed as water-supply wells during 1957 and 1963, respectively, and have been used as water-supply wells at least since the 1960 s (Young, 1972). Graves and others (1997, p. 41, 42, and 69) stated that from 1985 to 1995, water-level declines due to pumpage from these two wells were not observed in nearby wells in the Yucca Mountain area. However, it is not known if the water-level declines attributed to pumpage from the C-hole complex are due solely to the discharge from well UE-25 c\#3 or could be an accumulative effect from the pumpage from wells UE-25 J-12, UE-25 J-13, and UE-25 c\#3.

Hydrographs of wells monitored periodically show the periodic data. Hydrographs of the wells monitored hourly show the daily mean values of the hourly data and the manual periodic data collected following discontinuation of the hourly data collection. Only those hourly values that were evaluated as "valid" were used to calculate the daily mean values.

Annual minimum and maximum water-level altitudes are presented for each well. For wells monitored periodically, the range of water-level altitudes is from the periodic measurements. For wells monitored hourly the range of water-level altitudes is from the daily mean values of the hourly data and the manual data collected following discontinuation of the hourly data collection.

On average, mean 1996 water levels were lower than mean 1995 water levels, with the average difference being about $0.06 \mathrm{~m}$ lower. Of 29 depth intervals compared, 22 depth intervals had mean water levels lower (ranging from 0.01 to $0.19 \mathrm{~m}$ lower), 5 depth intervals had mean water levels higher (ranging from 0.03 to $0.10 \mathrm{~m}$ higher), and 2 depth intervals had the same water level. This comparison excluded well USW H-3, lower interval (which had a mean 1996 water level $0.84 \mathrm{~m}$ higher than 1995), and well USW G-2 (which, because of well pumpage, was not compared to 1995 data because some water-level measurements do not represent natural, undisturbed, conditions). The water-level rise in well USW H-3, lower interval, is anomalously large because the water level in this interval is still equilibrating in response to well reconfiguration during 1990.

In comparing the mean 1996 water levels to the mean 1985-95 water levels, the average difference was 0.03 $\mathrm{m}$ lower. Of 29 depth intervals compared, 17 depth intervals had mean water levels lower (ranging from 0.01 to $0.42 \mathrm{~m}$ lower), 10 depth intervals had mean water levels higher (ranging from 0.01 to $0.51 \mathrm{~m}$ higher), and 2 depth intervals had the same water level. As with the comparison between the 1996 and 1995 mean water levels, the comparison for the 1996 and 1985-95 mean water-level altitudes excluded wells USW H-3, lower interval, and USW G-2. 


\section{Well USW WT-1}

Information about the history of well USW WT-1 and about previous data from the well was obtained from various sources. These sources are: Robison (1984); J.H. Robison (U.S. Geological Survey, written commun., 1986); Robison and others (1988); Holmes \& Narver, Inc. (written commun., 1986); and Fenix \& Scisson, Inc. (1986a, 1987c).

\section{Well specifications}

1. Location and identification:

Latitude and longitude: $36^{\circ} 49^{\prime} 16^{\prime \prime} \mathrm{N}$.; $116^{\circ} 26^{\prime} 56^{\prime \prime} \mathrm{W}$.

Nevada State Central Zone Coordinates (m): N 229,801; E 171,828.

U.S. Geological Survey Site ID: 364916116265601.

2. Drilling and casing information:

Well started: April 28, 1983.

Well completed: May 18, 1983.

Drilling method: Rotary, using rock bits and air, water, and soap-circulating medium; core obtained from bottom of the borehole.

Bit diameter below water level: $222 \mathrm{~mm}$.

Casing: Surface casing only, to a depth of $9.91 \mathrm{~m}$.

Total drilled depth: $515 \mathrm{~m}$.

3. Access to and description of depth interval for measuring water levels:

62-mm-inside-diameter tubing that has a 3.7-m-long well screen on the bottom; tubing and attached screen extend from land surface to a depth of $507.5 \mathrm{~m}$; saturated interval of the borehole is within the Calico Hills Formation and Bullfrog Tuff of the Crater Flat Group.

4. Information for calculating water-level altitude:

Reference point: Top of metal tag on well casing, altitude $1,201.11 \mathrm{~m}$ (surveyed by U.S. Geological Survey in 1984).

Measuring point: Top of access tube, $0.314 \mathrm{~m}$ above reference point.

Depth correction for borehole deviation from vertical: $0.326 \mathrm{~m}$, based on approximate depth to water of 471 m (1990 data).

Well USW WT-1 was measured periodically during 1996, and water-level altitudes ranged from 730.04 to $730.32 \mathrm{~m}$ above sea level in 1996. The mean water-level altitude of the 1996 data was $730.17 \mathrm{~m}$ above sea level. This mean altitude was $0.14 \mathrm{~m}$ lower than the mean altitude of $730.31 \mathrm{~m}$ for 1995 (Graves and Goemaat, 1998) and $0.18 \mathrm{~m}$ lower than the mean altitude of $730.35 \mathrm{~m}$ for 1985-95 (Graves and others, 1997). The measured waterlevel altitudes are listed in table 5 and shown in figure 2. The lower water levels in well USW WT-1 are believed to be due to the pumpage at the C-hole complex that began on May 8, 1996. Through December 31, 1996, an estimated 196 million liters were pumped from well UE-25 $\mathrm{c} \# 3$. 
Table 5. Measured water-level altitudes, 1996, for well USW WT-1

\begin{tabular}{ccc}
\hline Date & $\begin{array}{c}\text { Measured water-tevel altitude } \\
\text { (meters above sea level) }\end{array}$ & Method of measuring water level \\
\hline $02-21-96$ & 730.30 & Chain \#3 \\
$05-23-96$ & 730.32 & Chain \#3 \\
$06-24-96$ & 730.30 & Chain \#3 \\
$07-17-96$ & 730.22 & Chain \#3 \\
$08-15-96$ & 730.12 & Chain \#3 \\
$09-23-96$ & 730.08 & Chain \#3 \\
$10-23-96$ & 730.12 & Chain \#3 \\
$11-12-96$ & 730.04 & Chain \#3 \\
$12-11-96$ & 730.06 & Chain \#3 \\
\hline
\end{tabular}

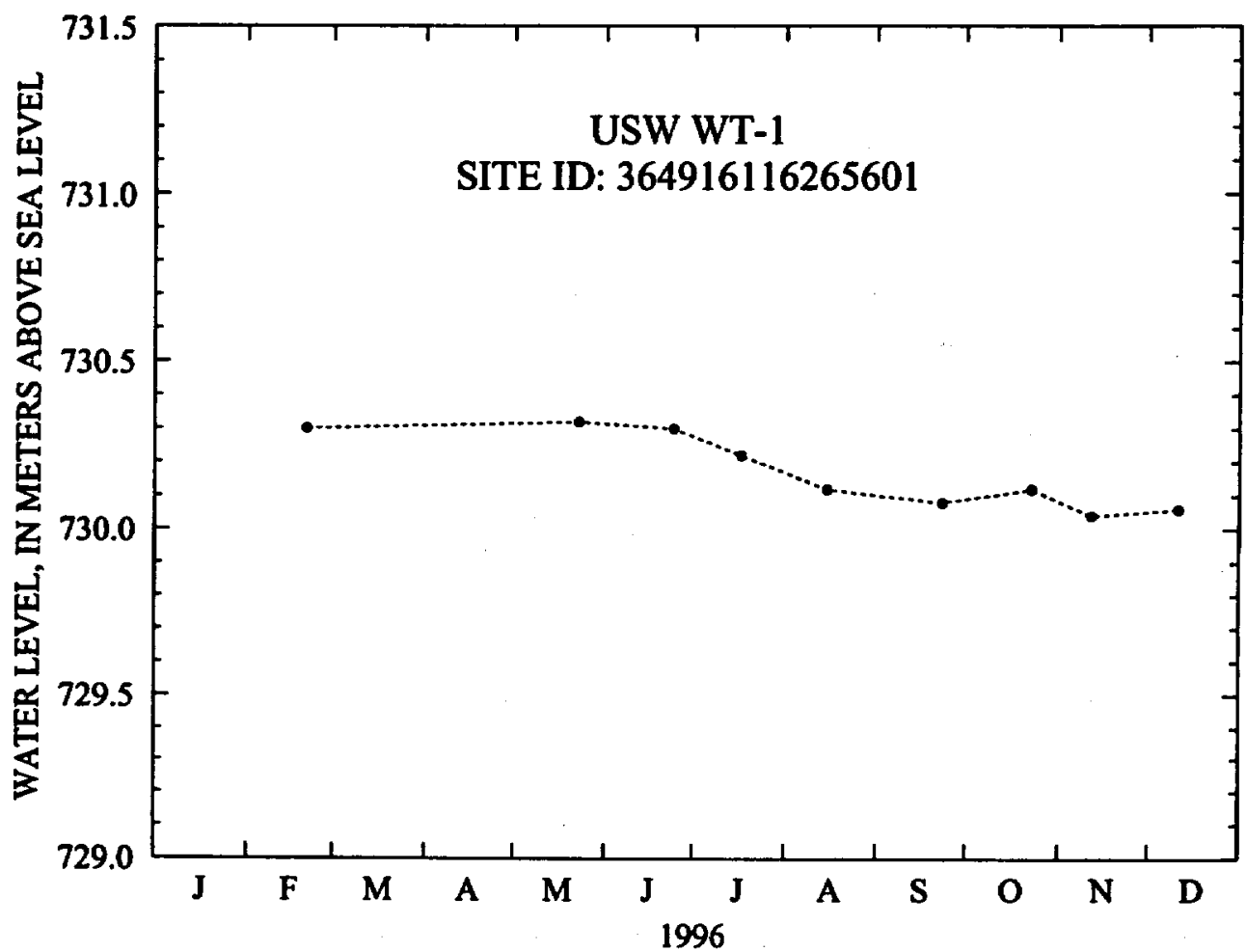

Figure 2. Water-level altitudes, 1996, for well USW WT-1. 


\section{Well USW WT-2}

Information about the history of well USW WT-2 and about previous data from the well was obtained from various sources. These sources are: Robison (1984); J.H. Robison (U.S. Geological Survey, written commun., 1986); Robison and others (1988); and Fenix \& Scisson, Inc. (1986a, 1987c).

Well specifications

1. Location and identification:

Latitude and longitude: $36^{\circ} 50^{\prime} 23^{\prime \prime} \mathrm{N}$.; $116^{\circ} 27^{\prime} 18^{\prime \prime} \mathrm{W}$.

Nevada State Central Zone Coordinates (m): N 231,849; E 171,274.

U.S. Geological Survey Site ID: 365023116271801.

2. Drilling and casing information:

Well started: July 8, 1983.

Well completed: July 16, 1983.

Drilling method: Rotary, using rock bits and air-foam circulating medium; core obtained from bottom of the borehole.

Bit diameter below water level: $222 \mathrm{~mm}$.

Casing: Surface casing only, to a depth of $18 \mathrm{~m}$.

Total drilled depth: $628 \mathrm{~m}$.

3. Access to and description of depth interval for measuring water levels:

62-mm-inside-diameter access tubing that has a 3.6-m-long well screen on bottom, extending from land surface to a depth of $622 \mathrm{~m}$; saturated interval of the borehole is within the Prow Pass Tuff of the Crater Flat Group.

4. Information for calculating water-level altitude:

Reference point: Top of metal tag on well casing; altitude $1,301.13 \mathrm{~m}$ (surveyed by U.S. Geological Survey in 1984).

Measuring point: Top of access tube, $0.305 \mathrm{~m}$ above reference point after December 8, 1993, $0.146 \mathrm{~m}$ above reference point between September 9, 1993, and December 8, 1993, and $0.311 \mathrm{~m}$ above reference point prior to September 9, 1993.

Depth correction for borehole deviation from vertical: $0.445 \mathrm{~m}$ after December 8, 1993 and $0.533 \mathrm{~m}$ prior to December 8, 1993, based on approximate depth to water of $571 \mathrm{~m}$.

Well USW WT-2 was measured periodically during 1996, and water-level altitudes ranged from 730.23 to $730.70 \mathrm{~m}$ above sea level in 1996 . The mean water-level altitude of the 1996 data was $730.52 \mathrm{~m}$ above sea level. This mean altitude was $0.05 \mathrm{~m}$ lower than the mean altitude of $730.57 \mathrm{~m}$ for 1995 (Graves and Goemaat, 1998) and $0.13 \mathrm{~m}$ lower than the mean altitude of $730.65 \mathrm{~m}$ for $1985-95$ (Graves and others, 1997). The measured waterlevel altitudes are listed in table 6 and shown in figure 3. 
Table 6. Measured water-level altitudes, 1996, for well USW WT-2

\begin{tabular}{ccc}
\hline Date & $\begin{array}{c}\text { Measured water-level altitude } \\
\text { (meters above sea level) }\end{array}$ & Method of measuring water level \\
\hline $02-21-96$ & 730.60 & Chain \#3 \\
$05-23-96$ & 730.60 & Chain \#3 \\
$06-25-96$ & 730.61 & Chain \#3 \\
$07-17-96$ & 730.70 & Chain \#3 \\
$08-14-96$ & 730.66 & Chain \#3 \\
$09-20-96$ & 730.63 & Chain \#3 \\
$10-21-96$ & 730.23 & Chain \#3 \\
$11-05-96$ & 730.27 & Chain \#3 \\
$12-10-96$ & 730.38 & Chain \#3 \\
\hline
\end{tabular}

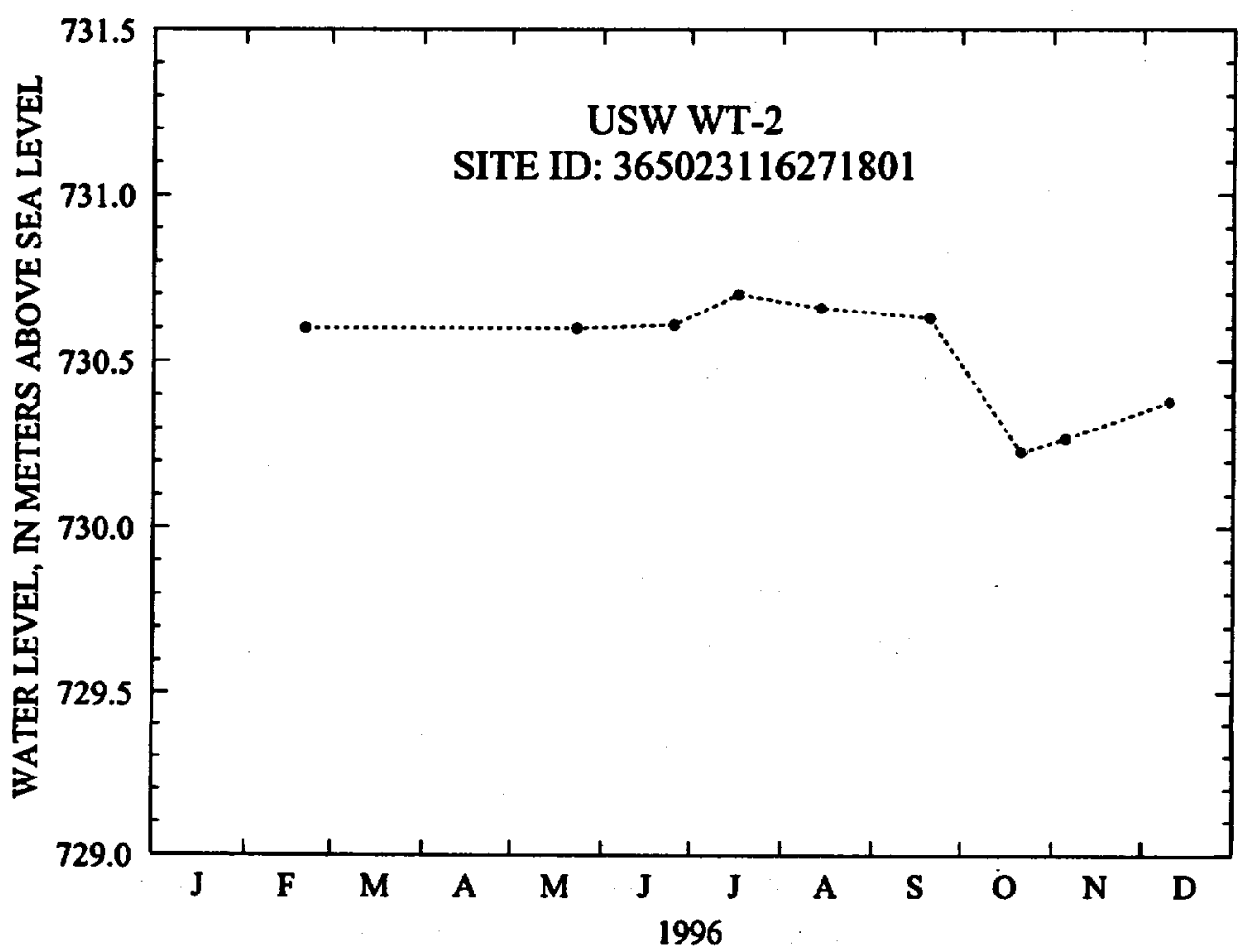

Figure 3. Water-level altitudes, 1996, for well USW WT-2. 


\section{Well UE-25 WT\#3}

Information about the history of well UE-25 WT\#3 and about previous data from the well was obtained from various sources. These sources are: Robison (1984); J.H. Robison (U.S. Geological Survey, written commun., 1986); Robison and others (1988); and Fenix \& Scisson, Inc. (1986a, 1987c). Well specifications

\section{Location and identification:}

Latitude and longitude: $36^{\circ} 47^{\prime} 57^{\prime \prime N}$.; $116^{\circ} 24^{\prime} 58^{\prime \prime} \mathrm{W}$.

Nevada State Central Zone Coordinates (m): N 227,379; E 174,768.

U.S. Geological Survey Site ID: 364757116245801.

2. Drilling and casing information:

Well started: April 29, 1983.

Well completed: May 25, 1983.

Drilling method: Rotary, using rock bits and air-foam circulating medium; core obtained from bottom of the borehole.

Bit diameter below water level: $222 \mathrm{~mm}$.

Casing: Surface casing only, to a depth of $12 \mathrm{~m}$.

Total drilled depth: $348 \mathrm{~m}$.

3. Access to and description of depth interval for measuring water levels:

62-mm-inside-diameter tubing that has a 3.6-m-long well screen on bottom, extending from land surface to a depth of $343 \mathrm{~m}$; saturated interval of the borehole is within the Bullfrog Tuff of the Crater Flat Group.

4. Information for calculating water-level altitude:

Reference point: Top of metal tag on well casing; altitude $1,030.11 \mathrm{~m}$ (surveyed by U.S. Geological Survey in 1984).

Measuring point: Top of access tubing, $0.155 \mathrm{~m}$ above reference point.

Depth correction for borehole deviation from vertical: $0.271 \mathrm{~m}$, based on approximate depth to water of $300 \mathrm{~m}$ (1990 data).

Well UE-25 WT\#3 was measured periodically ${ }^{2}$ during 1996, and water-level altitudes ranged from 729.54 to $729.68 \mathrm{~m}$ above sea level in 1996 . The mean water-level altitude of the 1996 data was $729.63 \mathrm{~m}$ above sea level. This mean altitude was $0.08 \mathrm{~m}$ lower than the mean altitude of $729.71 \mathrm{~m}$ for 1995 (Graves and Goemaat, 1998) and $0.01 \mathrm{~m}$ lower than the mean altitude of $729.64 \mathrm{~m}$ for $1985-95$ (Graves and others, 1997). The measured water-level altitudes are listed in table 7 and shown in figure 4 . It is suspected that the pumpage at the C-hole complex may be the reason for the lower water levels in well UE-25 WT\#3.

\footnotetext{
${ }^{2}$ Continuous data collection of well UE-25 WT\#3 was initiated on May 6, 1996, in support of scheduled hydraulic testing at the C-hole complex (fig. 1). Collection of the continuous data continued through December 31, 1996.
} 
Table 7. Measured water-level altitudes, 1996, for well UE-25 WT\#3

\begin{tabular}{ccc}
\hline Date & $\begin{array}{c}\text { Measured water-level altifude } \\
\text { (meters above sea level) }\end{array}$ & Method of measuring water level \\
\hline $02-21-96$ & 729.68 & Chain \#3 \\
$04-29-96$ & 729.64 & Chain \#3 \\
$05-06-96$ & 729.68 & Chain \#3 \\
$05-14-96$ & 729.67 & Chain \#3 \\
$08-27-96$ & 729.57 & Chain \#3 \\
$12-02-96$ & 729.54 & Chain \#3 \\
\hline
\end{tabular}

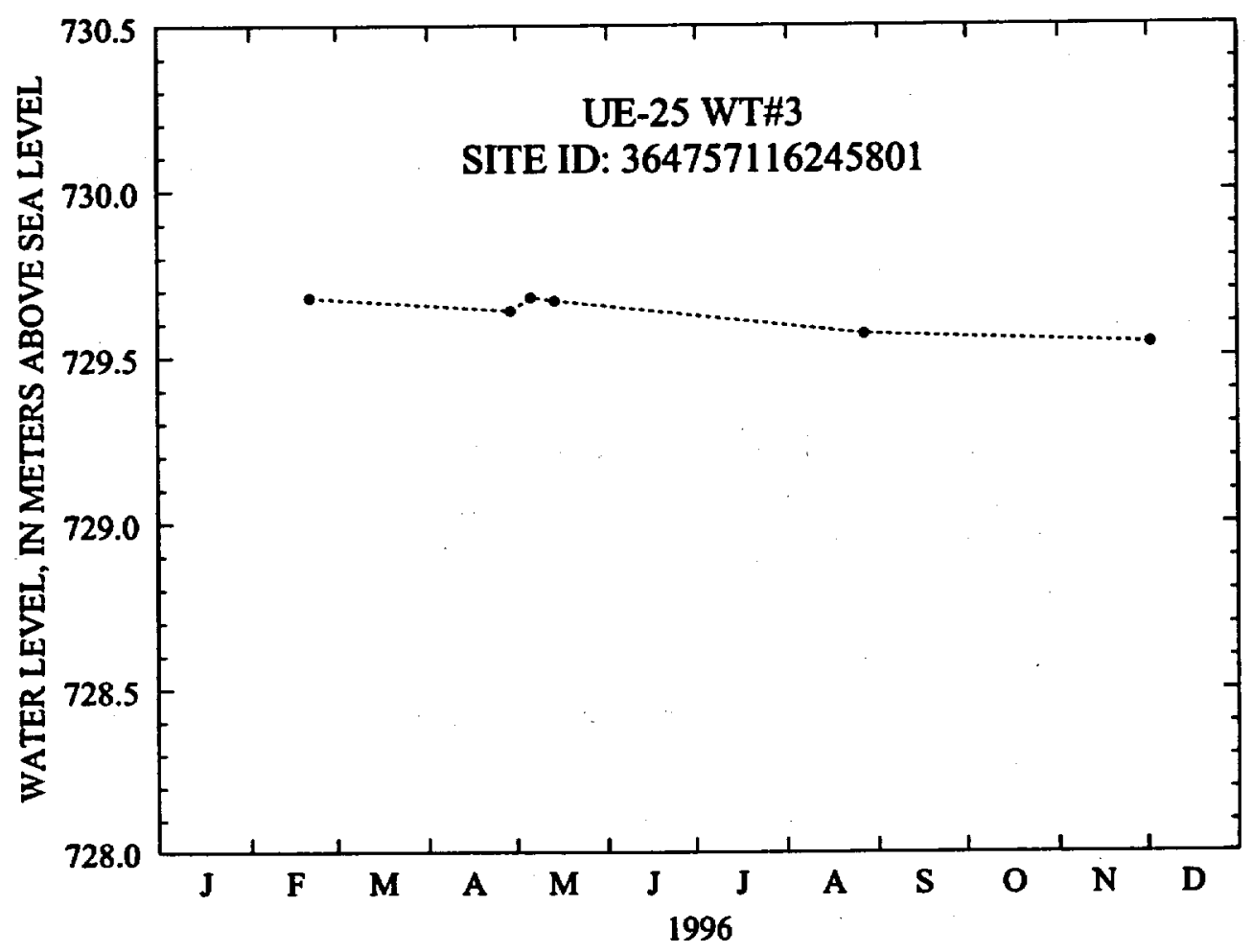

Figure 4. Water-level altitudes, 1996, for well UE-25 WT\#3. 


\section{Well UE-25 WT\#4}

Information about the history of well UE-25 WT\#4 and about previous data from the well was obtained from various sources. These sources are: Robison (1984); J.H. Robison (U.S. Geological Survey, written commun., 1986); Robison and others (1988); Holmes \& Narver, Inc. (written commun., 1986); and Fenix \& Scisson, Inc. (1986a, 1987c).

\section{Well specifications}

1. Location and identification:

Latitude and longitude: $36^{\circ} 51^{\prime} 40^{\prime \prime} \mathrm{N}$.; $116^{\circ} 26^{\prime} 03^{\prime \prime} \mathrm{W}$.

Nevada State Central Zone Coordinates (m): N 234,242; E 173,139.

U.S. Geological Survey Site ID: 365140116260301.

2. Drilling and casing information:

Well started: May 28, 1983.

Well completed: June 6, 1983.

Drilling method: Rotary, using rock bits and air-foam circulating medium; core obtained from bottom of the borehole.

Bit diameter below water level: $222 \mathrm{~mm}$.

Casing: Surface casing only, to a depth of $14.6 \mathrm{~m}$.

Total drilled depth: $482 \mathrm{~m}$.

3. Access to and description of depth interval for measuring water levels:

62-mm-inside-diameter tubing that has a 3.7-m-long well screen on the bottom; tubing and attached screen extend from land surface to a depth of $477.6 \mathrm{~m}$; saturated interval of the borehole is within the Calico Hills Formation.

4. Information for calculating water-level altitude:

Reference point: Top of metal tag on well casing, altitude $1,169.21 \mathrm{~m}$ (surveyed by U.S. Geological Survey in 1984).

Measuring point: Top of access tube, $0.311 \mathrm{~m}$ above reference point.

Depth correction for borehole deviation from vertical: $0.454 \mathrm{~m}$, based on approximate depth to water of $438 \mathrm{~m}$ (1990 data).

Well UE-25 WT\#4 was measured periodically during 1996, and water-level altitudes ranged from 730.51 to $730.81 \mathrm{~m}$ above sea level in 1996 . The mean water-level altitude of the 1996 data was $730.66 \mathrm{~m}$ above sea level. This mean altitude was $0.14 \mathrm{~m}$ lower than the mean altitude of $730.80 \mathrm{~m}$ for 1995 (Graves and Goemaat, 1998) and $0.12 \mathrm{~m}$ lower than the mean altitude of $730.78 \mathrm{~m}$ for $1985-95$ (Graves and others, 1997). The measured waterlevel altitudes are listed in table 8 and shown in figure 5. The lower water levels in well UE-25 WT\#4 are believed to be due to the pumpage at the C-hole complex that began on May 8, 1996. Through December 31, 1996, an estimated 196 million liters were pumped from well UE-25 $\mathrm{c \# 3.}$ 
Table 8. Measured water-level altitudes, 1996, for well UE-25 WT\#4

\begin{tabular}{ccc}
\hline Date & $\begin{array}{c}\text { Measured watertevel altitude } \\
\text { (meters above sea level) }\end{array}$ & Method of measuring water level \\
\hline $02-21-96$ & 730.81 & Chain \#3 \\
$05-23-96$ & 730.80 & Chain \#3 \\
$06-25-96$ & 730.72 & Chain \#3 \\
$07-17-96$ & 730.66 & Chain \#3 \\
$08-14-96$ & 730.63 & Chain \#3 \\
$09-20-96$ & 730.59 & Chain \#3 \\
$10-15-96$ & 730.61 & Chain \#3 \\
$11-06-96$ & 730.51 & Chain \#3 \\
$12-09-96$ & 730.61 & Chain \#3 \\
\hline
\end{tabular}

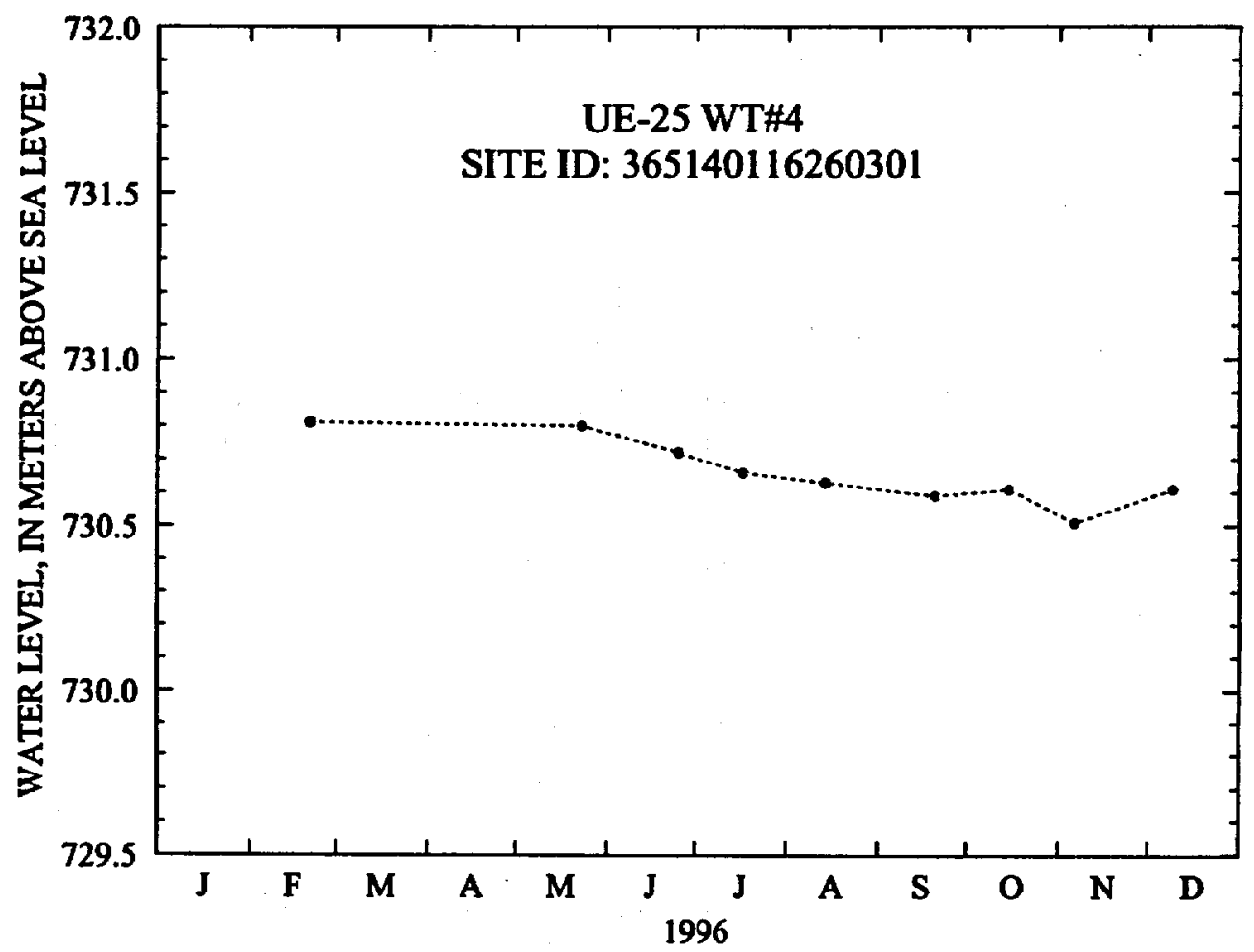

Figure 5. Water-level altitudes, 1996, for well UE-25 WT\#4. 


\section{Well UE-25 WT\#6}

Information about the history of well UE-25 WT\#6 and about previous data from the well was obtained from various sources. These sources are: Robison (1984); J.H. Robison (U.S. Geological Survey, written commun., 1986); Robison and others (1988); and Fenix \& Scisson, Inc. (1986a, 1987c).

Well specifications

1. Location and identification:

Latitude and longitude: $36^{\circ} 53^{\prime} 40^{\prime \prime} \mathrm{N}$.; $116^{\circ} 26^{\prime} 46^{\prime \prime} \mathrm{W}$.

Nevada State Central Zone Coordinates (m): N 237,920; E 172,067.

U.S. Geological Survey Site ID: 365340116264601.

2. Drilling and casing information:

Well started: June 20, 1983.

Well completed: June 29, 1983.

Drilling method: Rotary, using rock bits and air-foam circulating medium; core obtained from bottom of the borehole.

Bit diameter below water level: $171 \mathrm{~mm}$.

Casing: Surface casing only, to a depth of $76.5 \mathrm{~m}$.

Total drilled depth: $383 \mathrm{~m}$.

3. Access to and description of depth interval for measuring water levels:

62-mm-inside-diameter tubing that has a 3.6-m-long well screen on bottom, extending from land surface to a depth of $372 \mathrm{~m}$; saturated interval of the borehole is within the Calico Hills Formation.

4. Information for calculating water-level altitude:

Reference point: Top of metal tag on well casing; altitude $1,314.78 \mathrm{~m}$ (surveyed by

U.S. Geological Survey in 1984).

Measuring point: Top of access tube, $0.463 \mathrm{~m}$ above reference point.

Depth correction for borehole deviation from vertical: $0.204 \mathrm{~m}$, based on approximate

depth to water of $280 \mathrm{~m}$ (1990 data).

Well UE-25 WT\#6 was measured periodically during 1996, and water-level altitudes ranged from $1,034.39$ to $1,034.72 \mathrm{~m}$ above sea level in 1996 . The mean water-level altitude of the 1996 data was $1,034.58 \mathrm{~m}$ above sea level. This mean altitude was $0.10 \mathrm{~m}$ higher than the mean altitude of $1,034.48 \mathrm{~m}$ for 1995 (Graves and Goemaat, 1998) and $0.02 \mathrm{~m}$ lower than the mean altitude of $1,034.60 \mathrm{~m}$ for 1985-95 (Graves and others, 1997). The measured water-level altitudes are listed in table 9 and shown in figure 6.

A shift in water level occurred in well UE-25 WT\#6 during July; the water level rose about $0.27 \mathrm{~m}$. The reason for this rise in water level is unknown; however, water levels did not decline following this rise. The trend in water level observed from mid-July through the end of 1996 was approximately $0.21 \mathrm{~m}$ higher than the trend in water level observed from February 1996 through mid-July. 
Table 9. Measured water-level altitudes, 1996, for well UE-25 WT\#6

\begin{tabular}{ccc}
\hline Date & $\begin{array}{c}\text { Measured water-fevel altitude } \\
\text { (meters above sea level) }\end{array}$ & Method of measuring water level \\
\hline $02-12-96$ & $1,034.50$ & Chain \#3 \\
$05-22-96$ & $1,034.49$ & Chain \#3 \\
$06-26-96$ & $1,034.42$ & Chain \#3 \\
$07-18-96$ & $1,034.39$ & Chain \#3 \\
$07-24-96$ & $1,034.66$ & $2,800-$ foot reference steel tape \\
$08-22-96$ & $1,034.64$ & $2,800-$ foot reference steel tape \\
$09-09-96$ & $1,034.64$ & $2,800-$ foot reference steel tape \\
$10-15-96$ & $1,034.65$ & Chain \#3 \\
$11-05-96$ & $1,034.68$ & Chain \#3 \\
$12-09-96$ & $1,034.72$ & Chain \#3 \\
\hline
\end{tabular}

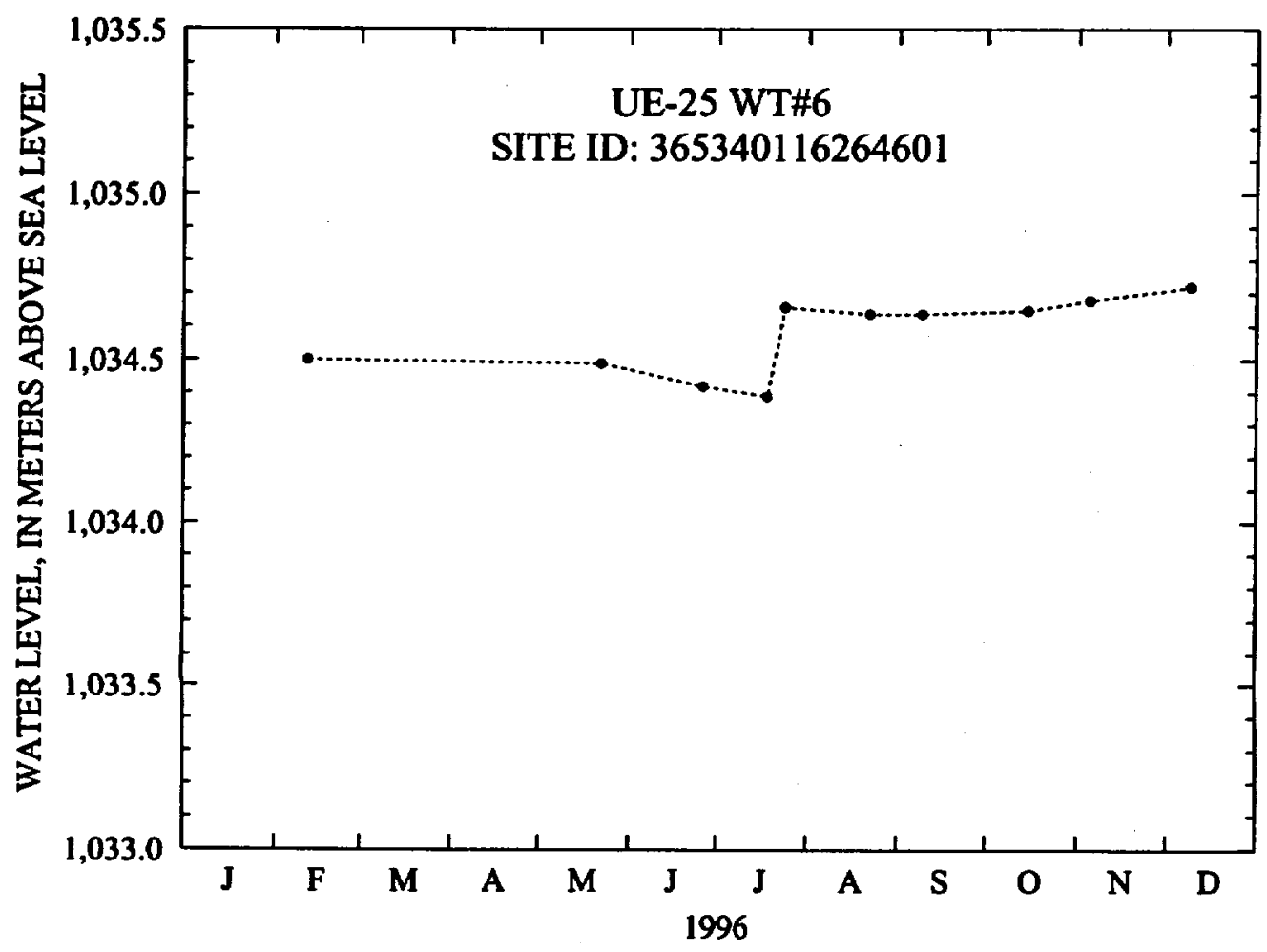

Figure 6. Water-level altitudes, 1996, for well UE-25 WT\#6. 


\section{Well USW WT-7}

Information about the history or well USW WT-7 and about previous data from the well was obtained from various sources. These sources are: Robison (1984); J.H. Robison (U.S. Geological Survey, written commun., 1986); Robison and others (1988); Holmes \& Narver, Inc. (written commun., 1986); and Fenix \& Scisson, Inc. (1986a, 1987c).

\section{Well specifications}

\section{Location and identification:}

Latitude and longitude: $36^{\circ} 49^{\prime} 33^{\prime \prime N}$.; $116^{\circ} 28^{\prime} 57^{\prime \prime} \mathrm{W}$.

Nevada State Central Zone Coordinates (m): N 230,298; E 168,826.

U.S. Geological Survey Site ID: 364933116285701.

2. Drilling and casing information:

Well started: July 19, 1983.

Well completed: July 26, 1983.

Drilling method: Rotary, using rock bits and air-foam circulating medium; core obtained from bottom of the borehole.

Bit diameter below water level: $222 \mathrm{~mm}$.

Casing: Surface casing only, to a depth of $15.8 \mathrm{~m}$.

Total drilled depth: $491 \mathrm{~m}$.

3. Access to and description of depth interval for measuring water levels:

62-mm-inside-diameter tubing that has a 3.7-m-long well screen on the bottom; tubing and attached screen extend from land surface to a depth of $481.3 \mathrm{~m}$; saturated interval of the borehole is within the Topopah Spring Tuff of the Paintbrush Group and the Prow Pass Tuff of the Crater Flat Group.

4. Information for calculating water-level altitude:

Reference point: Top of metal tag on well casing, altitude $1,196.88 \mathrm{~m}$ (surveyed by U.S. Geological Survey in 1984).

Measuring point: Top of access tube, $0.302 \mathrm{~m}$ above reference point.

Depth correction for borehole deviation from vertical: $0.034 \mathrm{~m}$, based on approximate depth to water of $421 \mathrm{~m}$ (1990 data).

Well USW WT-7 was measured periodically during 1996, and water-level altitudes ranged from 775.92 to $776.00 \mathrm{~m}$ above sea level in 1996 . The mean water-level altitude of the 1996 data was $775.96 \mathrm{~m}$ above sea level. This mean altitude was $0.03 \mathrm{~m}$ higher than the mean altitude of $775.93 \mathrm{~m}$ for 1995 (Graves and Goemaat, 1998) and $0.13 \mathrm{~m}$ higher than the mean altitude of $775.83 \mathrm{~m}$ for 1985-95 (Graves and others, 1997). The measured waterlevel altitudes are listed in table 10 and shown in figure 7. 
Table 10. Measured water-level altitudes, 1996, for well USW WT-7

\begin{tabular}{ccc}
\hline Date & $\begin{array}{c}\text { Measured water-level altitude } \\
\text { (meters above sea level) }\end{array}$ & Method of measuring water level \\
\hline $02-26-96$ & 775.97 & Chain \#3 \\
$05-22-96$ & 775.99 & Chain \#3 \\
$06-19-96$ & 776.00 & Chain \#3 \\
$07-16-96$ & 775.99 & Chain \#3 \\
$08-12-96$ & 775.97 & Chain \#3 \\
$09-17-96$ & 775.92 & Chain \#3 \\
$10-16-96$ & 775.97 & Chain \#3 \\
$11-13-96$ & 775.93 & Chain \#3 \\
$12-12-96$ & 775.92 & Chain \#3 \\
\hline
\end{tabular}

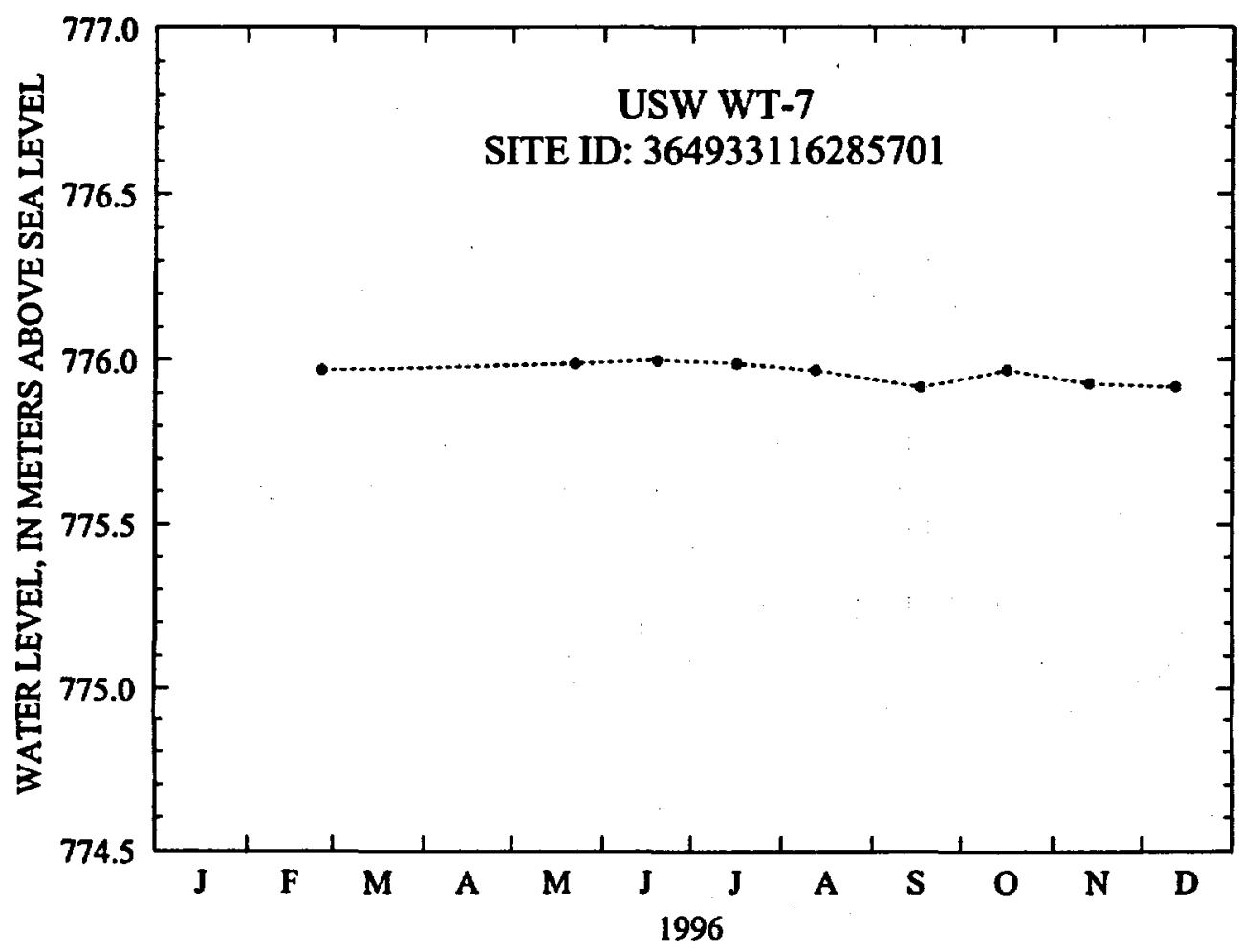

Figure 7. Water-level altitudes, 1996, for well USW WT-7. 


\section{Well USW WT-10}

Information about the history of well USW WT-10 and about previous data from the well was obtained from various sources. These sources are: Robison (1984); J.H. Robison (U.S. Geological Survey, written commun., 1986); Robison and others (1988); Holmes \& Narver, Inc. (written commun., 1986); and Fenix \& Scisson, Inc. (1986a, 1987c).

\section{Well specifications}

1. Location and identification:

Latitude and longitude: $36^{\circ} 48^{\prime} 25^{\prime \prime} \mathrm{N}$.; $116^{\circ} 29^{\prime} 05^{\prime \prime} \mathrm{W}$.

Nevada State Central Zone Coordinates (m): N 228,225; E 168,646.

U.S. Geological Survey Site ID: 364825116290501.

2. Drilling and casing information:

Well started: July 26, 1983.

Well completed: August 2, 1983.

Drilling method: Rotary, using rock bits and air-foam circulating medium; core obtained from bottom of the borehole.

Bit diameter below water level: $222 \mathrm{~mm}$.

Casing: Surface casing only, to a depth of $34.7 \mathrm{~m}$.

Total drilled depth: $431 \mathrm{~m}$.

3. Access to and description of depth interval for measuring water levels:

62-mm-inside-diameter tubing that has a $3.7-\mathrm{m}$-long well screen on the bottom; tubing and attached screen extend from land surface to a depth of $402.6 \mathrm{~m}$; saturated interval of the borehole is within the Topopah Spring Tuff of the Paintbrush Group.

4. Information for calculating water-level altitude:

Reference point: Top of metal tag on well casing, altitude $1,123.40 \mathrm{~m}$ (surveyed by U.S. Geological Survey in 1984).

Measuring point: Top of access tube, $0.314 \mathrm{~m}$ above reference point.

Depth correction for borehole deviation from vertical: $0.030 \mathrm{~m}$, based on approximate depth to water of $347 \mathrm{~m}$ (1990 data).

Well USW WT-10 was measured periodically during 1996, and water-level altitudes ranged from 776.04 to $776.39 \mathrm{~m}$ above sea level in 1996. The mean water-level altitude of the 1996 data was $776.11 \mathrm{~m}$ above sea level. This mean altitude was $0.01 \mathrm{~m}$ lower than the mean altitude of $776.12 \mathrm{~m}$ for 1995 (Graves and Goemaat, 1998) and $0.11 \mathrm{~m}$ higher than the mean altitude of $776.00 \mathrm{~m}$ for $1985-95$ (Graves and others, 1997). The measured waterlevel altitudes are listed in table 11 and shown in figure 8.

A sudden rise of approximately $0.30 \mathrm{~m}$ in water level in well USW WT-10 was observed from May to June 1996. By July 1996, the water level had declined back to the May water level. The reason for the sudden rise in water level is not known; however, rises in water levels for the same time period were observed in wells USW H-1, tubes 1, 2, 3, and 4, USW H-6, lower interval, and UE-25 J-13. 
Table 11. Measured water-level altitudes, 1996, for well USW WT-10

\begin{tabular}{ccc}
\hline Date & $\begin{array}{c}\text { Measured water-level attltude } \\
\text { (meters above sea level) }\end{array}$ & Method of measuring water level \\
\hline $01-09-96$ & 776.07 & Chain \#3 \\
$01-22-96$ & 776.07 & Chain \#3 \\
$02-07-96$ & 776.13 & Chain \#3 \\
$05-21-96$ & 776.09 & Chain \#3 \\
$06-19-96$ & 776.39 & Chain \#3 \\
$07-16-96$ & 776.09 & Chain \#3 \\
$08-12-96$ & 776.10 & Chain \#3 \\
$09-17-96$ & 776.04 & Chain \#3 \\
$10-16-96$ & 776.12 & Chain \#3 \\
$11-13-96$ & 776.06 & Chain \#3 \\
$12-12-96$ & 776.04 & Chain \#3 \\
\hline
\end{tabular}

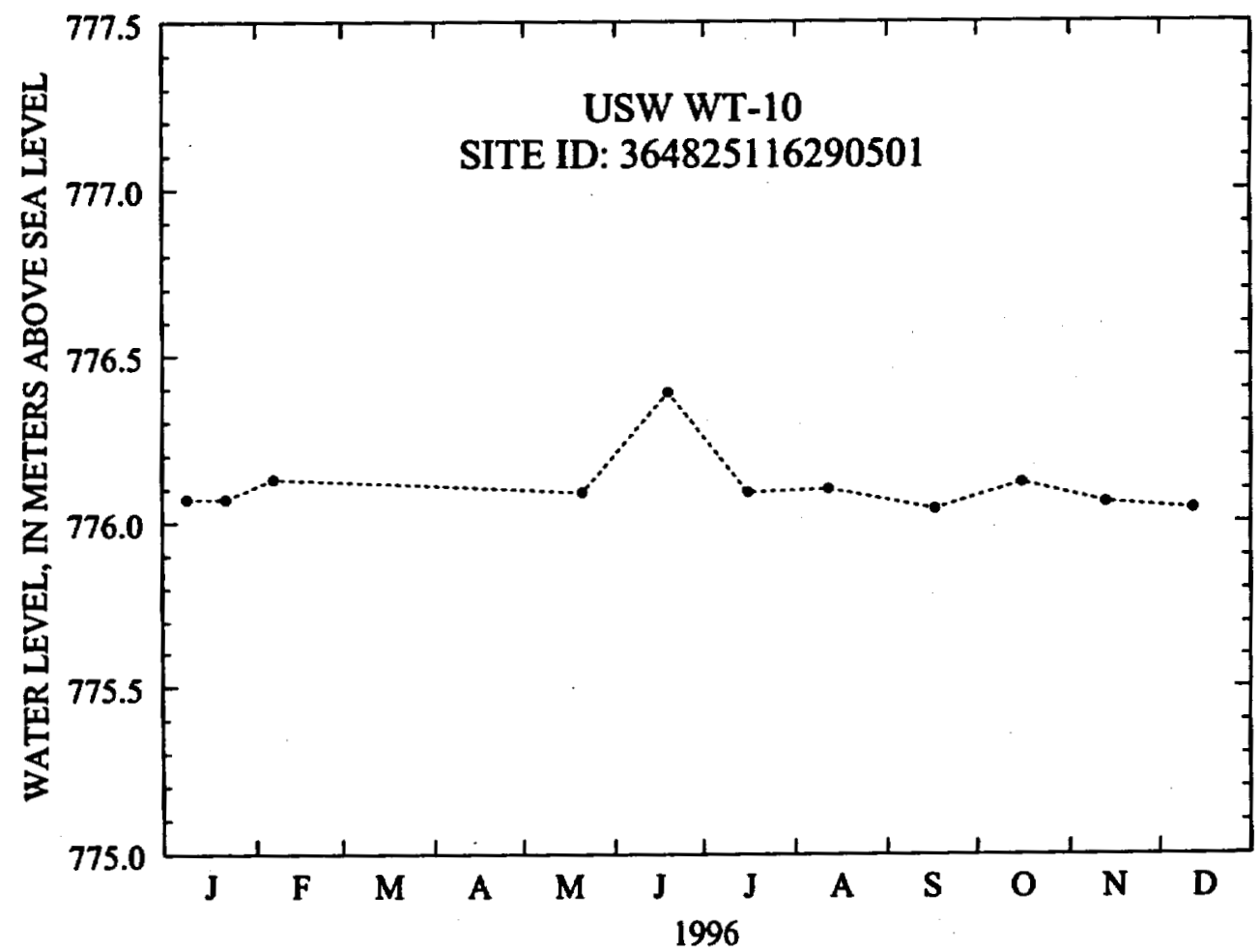

Figure 8. Water-level altitudes, 1996, for well USW WT-10. 


\section{Well USW WT-11}

Information about the history of well USW WT-11 and about previous data from the well was obtained from various sources. These sources are: Robison (1984); J.H. Robison (U.S. Geological Survey, written commun., 1986); Robison and others (1988); and Fenix \& Scisson, Inc. (1986a, 1987c).

Well specifications

1. Location and identification:

Latitude and longitude: $36^{\circ} 46^{\prime} 49^{\prime \prime N}$.; $116^{\circ} 28^{\prime} 02^{\prime \prime} \mathrm{W}$.

Nevada State Central Zone Coordinates (m): N 225,269; E 170,193.

U.S. Geological Survey Site ID: 364649116280201.

2. Drilling and casing information:

Well started: August 3, 1983.

Well completed: August 9, 1983.

- Drilling method: Rotary, using rock bits and air-foam circulating medium; core obtained from bottom of the borehole.

Bit diameter below water level: $222 \mathrm{~mm}$.

Casing: Surface casing only, to a depth of $14 \mathrm{~m}$.

Total drilled depth: $441 \mathrm{~m}$.

3. Access to and description of depth interval for measuring water levels:

62-mm-inside-diameter tubing that has a 3.6-m-long well screen on bottom, extending from land surface to a depth of $416 \mathrm{~m}$; saturated interval of the borehole is within the Topopah Spring Tuff of the Paintbrush Group and the Calico Hills Formation.

4. Information for calculating water-level altitude:

Reference point: Top of metal tag on well casing; altitude $1,094.11 \mathrm{~m}$ (surveyed by U.S. Geological Survey in 1984).

Measuring point: Top of access tube, $0.311 \mathrm{~m}$ above reference point.

Depth correction for borehole deviation from vertical: $0.116 \mathrm{~m}$, based on approximate depth to water of $363 \mathrm{~m}$ (1990 data).

Well USW WT-11 was measured periodically during 1996, and water-level altitudes for well USW WT-11 ranged from 730.47 to $730.66 \mathrm{~m}$ above sea level in 1996. The mean water-level altitude of the 1996 data was $730.58 \mathrm{~m}$ above sea level. This mean altitude was $0.11 \mathrm{~m}$ lower than the mean altitude of $730.69 \mathrm{~m}$ for 1995 (Graves and Goemaat, 1998) and $0.08 \mathrm{~m}$ lower than the mean altitude of $730.66 \mathrm{~m}$ for $1985-95$ (Graves and others, 1997). The measured water-level altitudes are listed in table 12 and shown in figure 9. It is suspected that the pumpage at the C-hole complex may be the reason for the lower water levels in well USW WT- 11 . 
Table 12. Measured water-level altitudes, 1996, for well USW WT-11

\begin{tabular}{|c|c|c|}
\hline Date & $\begin{array}{l}\text { Measured water-level altitude } \\
\text { (meters above sea level) }\end{array}$ & Method of measuring water level \\
\hline $02-07-96$ & 730.61 & Chain \#3 \\
\hline $05-21-96$ & 730.66 & Chain \#3 \\
\hline 06-19-96 & 730.66 & Chain \#3 \\
\hline $07-16-96$ & 730.59 & Chain \#3 \\
\hline $08-12-96$ & 730.60 & Chain \#3 \\
\hline $09-17-96$ & 730.55 & Chain \#3 \\
\hline $10-16-96$ & 730.57 & Chain \#3 \\
\hline $11-13-96$ & 730.47 & Chain \#3 \\
\hline $12-12-96$ & 730.48 & Chain \#3 \\
\hline
\end{tabular}

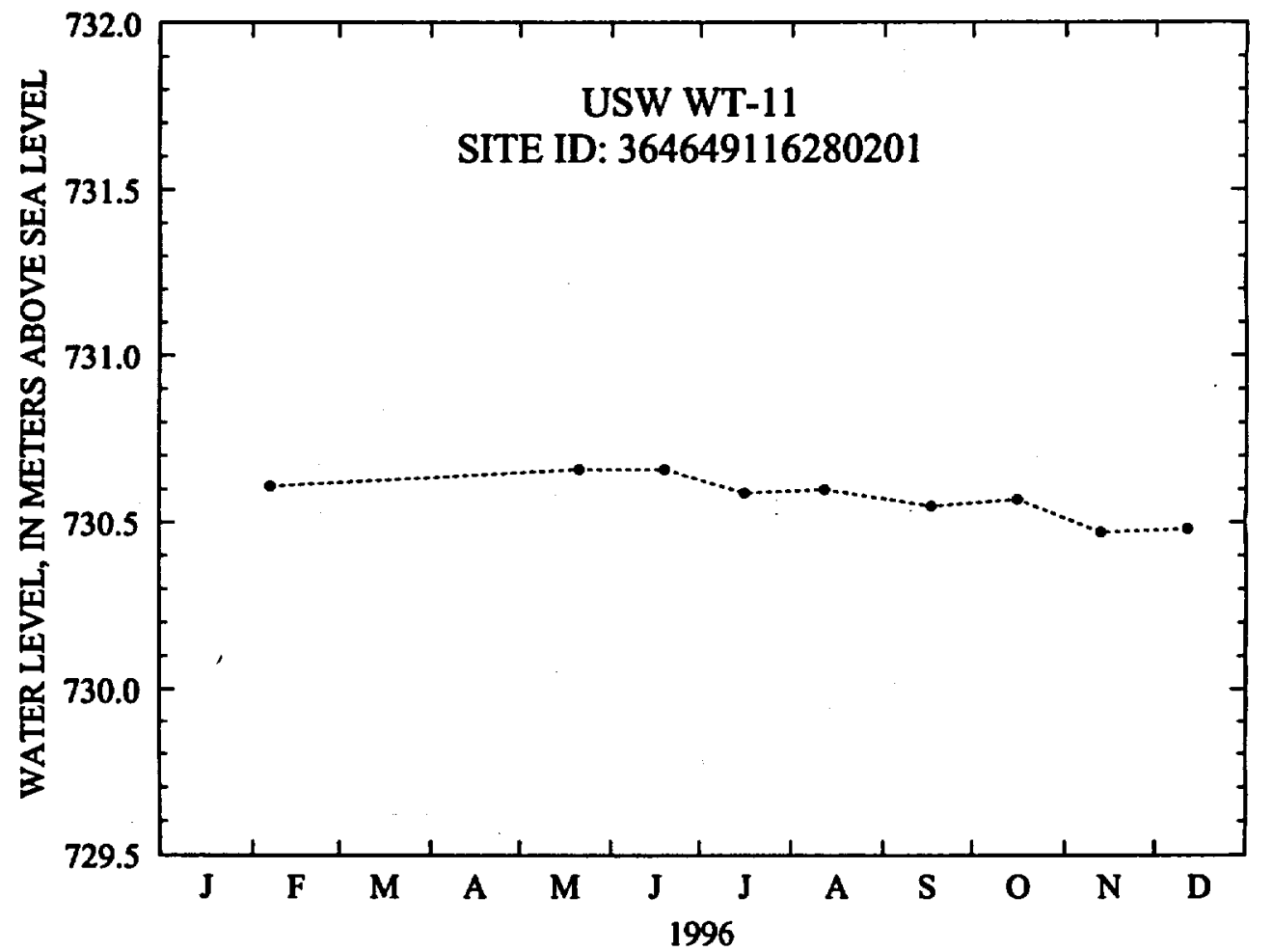

Figure 9. Water-level altitudes, 1996, for well USW WT-11. 


\section{Well UE-25 WT\#13}

Information about the history of well UE-25 WT\#13 and about previous data from the well was obtained from various sources. These sources are: Robison (1984); J.H. Robison (U.S. Geological Survey, written commun., 1986); Robison and others (1988); and Fenix \& Scisson, Inc. (1986a, 1987c).

Well specifications

1. Location and identification:

Latitude and longitude: $36^{\circ} 49^{\circ} 43^{\prime \prime} \mathrm{N}$.; $116^{\circ} 23^{\prime} 51^{\prime \prime} \mathrm{W}$.

Nevada State Central Zone Coordinates (m): N 230,647; E 176,405.

U.S. Geological Survey Site ID: 364945116235001.

2. Drilling and casing information:

Well started: June 29, 1983.

Well completed: July 7, 1983.

Drilling method: Rotary, using rock bits and air-foam circulating medium; core obtained from bottom of the borehole.

Bit diameter below water level: $222 \mathrm{~mm}$.

Casing: Surface casing only, to a depth of $68 \mathrm{~m}$.

Total drilled depth: $354 \mathrm{~m}$.

3. Access to and description of depth interval for measuring water levels:

62-mm-inside-diameter tubing that has a 3.6-m-long well screen on bottom, extending from land surface to a depth of $346 \mathrm{~m}$; saturated interval of the borehole is within the Topopah Spring Tuff of the Paintbrush Group.

4. Information for calculating water-level altitude:

Reference point: Top of metal tag on well casing; altitude $1,032.51 \mathrm{~m}$ (surveyed by

U.S. Geological Survey in 1984).

Measuring point: Top of access tube, $0.305 \mathrm{~m}$ above reference point.

Depth correction for borehole deviation from vertical: $0.012 \mathrm{~m}$, based on approximate depth to water of $304 \mathrm{~m}$ (1990 data).

Well UE-25 WT\#13 was measured periodically during 1996, and water-level altitudes ranged from 728.95 to $729.18 \mathrm{~m}$ above sea level in 1996 . The mean water-level altitude of the 1996 data was $729.11 \mathrm{~m}$ above sea level. This mean altitude was $0.07 \mathrm{~m}$ lower than the mean altitude of $729.18 \mathrm{~m}$ for 1995 (Graves and Goemaat, 1998) and the same as the mean altitude of $729.11 \mathrm{~m}$ for 1985-95 (Graves and others, 1997). The measured water-level altitudes are listed in table 13 and shown in figure 10. 
Table 13. Measured water-level altitudes, 1996, for well UE-25 WT\#13

\begin{tabular}{ccc}
\hline Date & $\begin{array}{c}\text { Measured water-level altitude } \\
\text { (meters above sea level) }\end{array}$ & Method of measuring water level \\
\hline $02-15-96$ & 729.12 & Chain \#3 \\
$05-23-96$ & 729.13 & Chain \#3 \\
$06-26-96$ & 729.17 & Chain \#3 \\
$07-17-96$ & 729.17 & Chain \#3 \\
$08-14-96$ & 729.14 & Chain \#3 \\
$09-18-96$ & 729.05 & Chain \#3 \\
$10-21-96$ & 728.95 & Chain \#3 \\
$11-06-96$ & 729.05 & Chain \#3 \\
$12-09-96$ & 729.18 & Chain \#3 \\
\hline
\end{tabular}

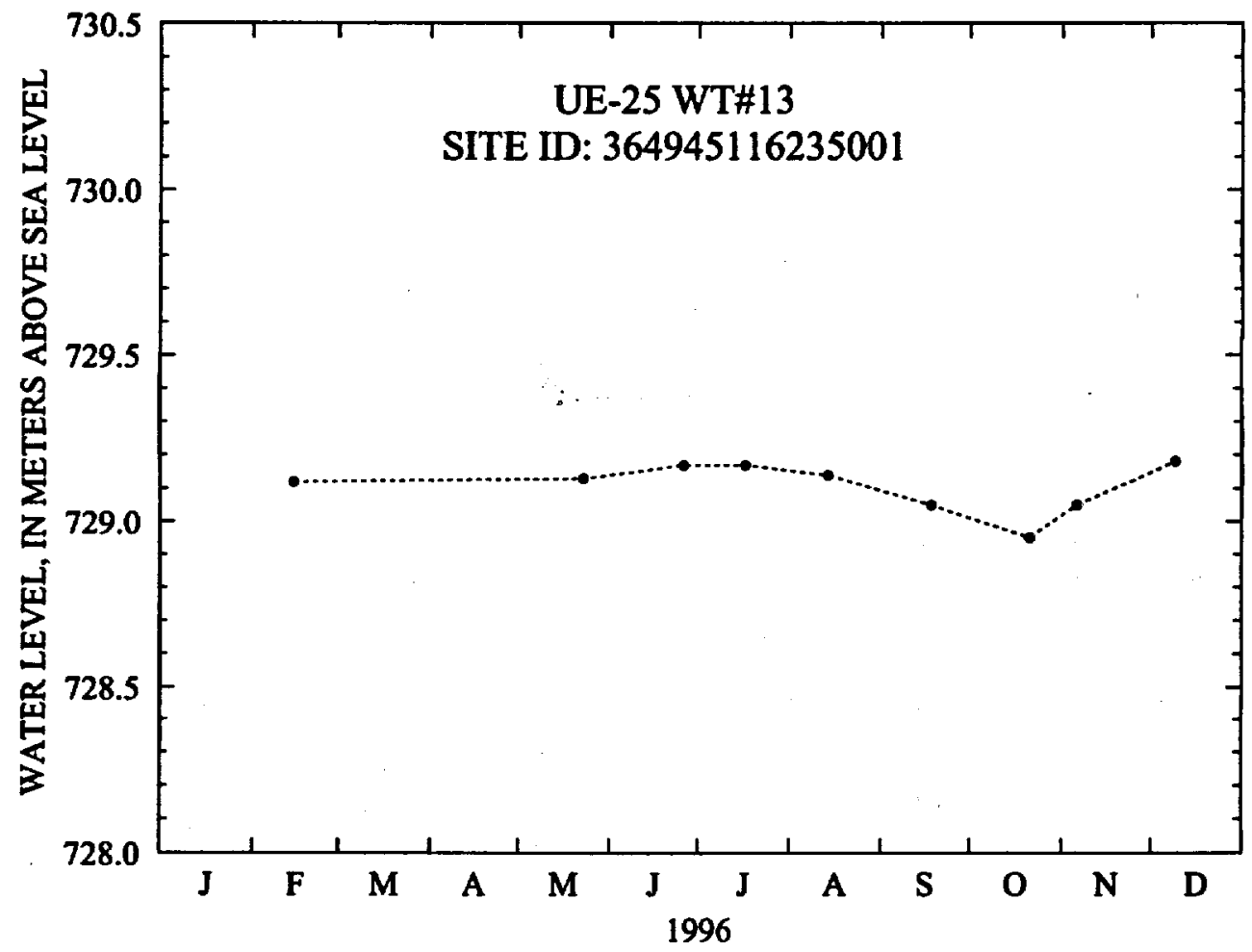

Figure 10. Water-level altitudes, 1996, for well UE-25 WT\#13. 


\section{Well UE-25 WT\#14}

Information about the history of well UE-25 WT\#14 and about previous data from the well was obtained from various sources. These sources are: Robison (1984); J.H. Robison (U.S. Geological Survey, written commun., 1986); Robison and others (1988); Holmes \& Narver, Inc. (written commun., 1986); and Fenix \& Scisson, Inc. (1986a, 1987c).

\section{Well specifications}

1. Location and identification:

Latitude and longitude: $36^{\circ} 50^{\prime} 32^{\prime \prime} \mathrm{N} . ; 116^{\circ} 24^{\prime} 35^{\prime \prime} \mathrm{W}$.

Nevada State Central Zone Coordinates (m): N 232,151; E 175,324.

U.S. Geological Survey Site ID: 365032116243501.

2. Drilling and casing information:

Well started: August 17, 1983.

Well completed: September 30, 1983.

Drilling method: Rotary, using rock bits and air-foam circulating medium; core obtained from bottom of the borehole.

Bit diameter below water level: $222 \mathrm{~mm}$.

Casing: Surface casing only, to a depth of $36.6 \mathrm{~m}$.

Total drilled depth: $399 \mathrm{~m}$.

3. Access to and description of depth interval for measuring water levels:

62-mm-inside-diameter tubing that has a 3.7-m-long well screen on the bottom; tubing and attached screen extend from land surface to a depth of $397.2 \mathrm{~m}$; saturated interval of the borehole is within the Topopah Spring Tuff of the Paintbrush Group and the Calico Hills Formation.

4. Information for calculating water-level altitude:

Reference point: Top of metal tag on well casing, altitude $1,076.05 \mathrm{~m}$ (surveyed by U.S. Geological Survey in 1984).

Measuring point: Top of access tube, $0.311 \mathrm{~m}$ above reference point.

Depth correction for borehole deviation from vertical: $0.085 \mathrm{~m}$, based on approximate depth to water of $346 \mathrm{~m}$ (1990 data).

Well UE-25 WT\#14 was measured periodically ${ }^{3}$ during 1996, and water-level altitudes ranged from 729.48 to $729.65 \mathrm{~m}$ above sea level in 1996 . The mean water-level altitude of the 1996 data was $729.58 \mathrm{~m}$ above sea level. This mean altitude was $0.07 \mathrm{~m}$ lower than the mean altitude of $729.65 \mathrm{~m}$ for 1995 (Graves and Goemaat, 1998) and $0.10 \mathrm{~m}$ lower than the mean altitude of $729.68 \mathrm{~m}$ for $1985-95$ (Graves and others, 1997). The measured waterlevel altitudes are listed in table 14 and shown in figure 11. The lower water levels in well UE-25 WT\#14 are believed to be due to the pumpage at the C-hole complex that began on May 8, 1996. Through December 31, 1996, an estimated 196 million liters was pumped from well UE-25 c\#3.

\footnotetext{
${ }^{3}$ Continuous data collection from well UE-25 WT\#14 was initiated on May 7, 1996, in support of scheduled hydraulic testing at the C-hole complex (fig. 1). Collection of the continuous data continued through December 31, 1996.
} 
Table 14. Measured water-level altitudes, 1996, for well UE-25 WT\#14

\begin{tabular}{ccc}
\hline Date & $\begin{array}{c}\text { Measured water-level altitude } \\
\text { (meters above sea level) }\end{array}$ & Method of measuring water level \\
\hline $02-15-96$ & 729.64 & Chain \#3 \\
$04-24-96$ & 729.65 & Chain \#3 \\
$05-07-96$ & 729.65 & Chain \#3 \\
$08-29-96$ & 729.48 & Chain \#3 \\
$12-03-96$ & 729.48 & Chain \#3 \\
\hline
\end{tabular}

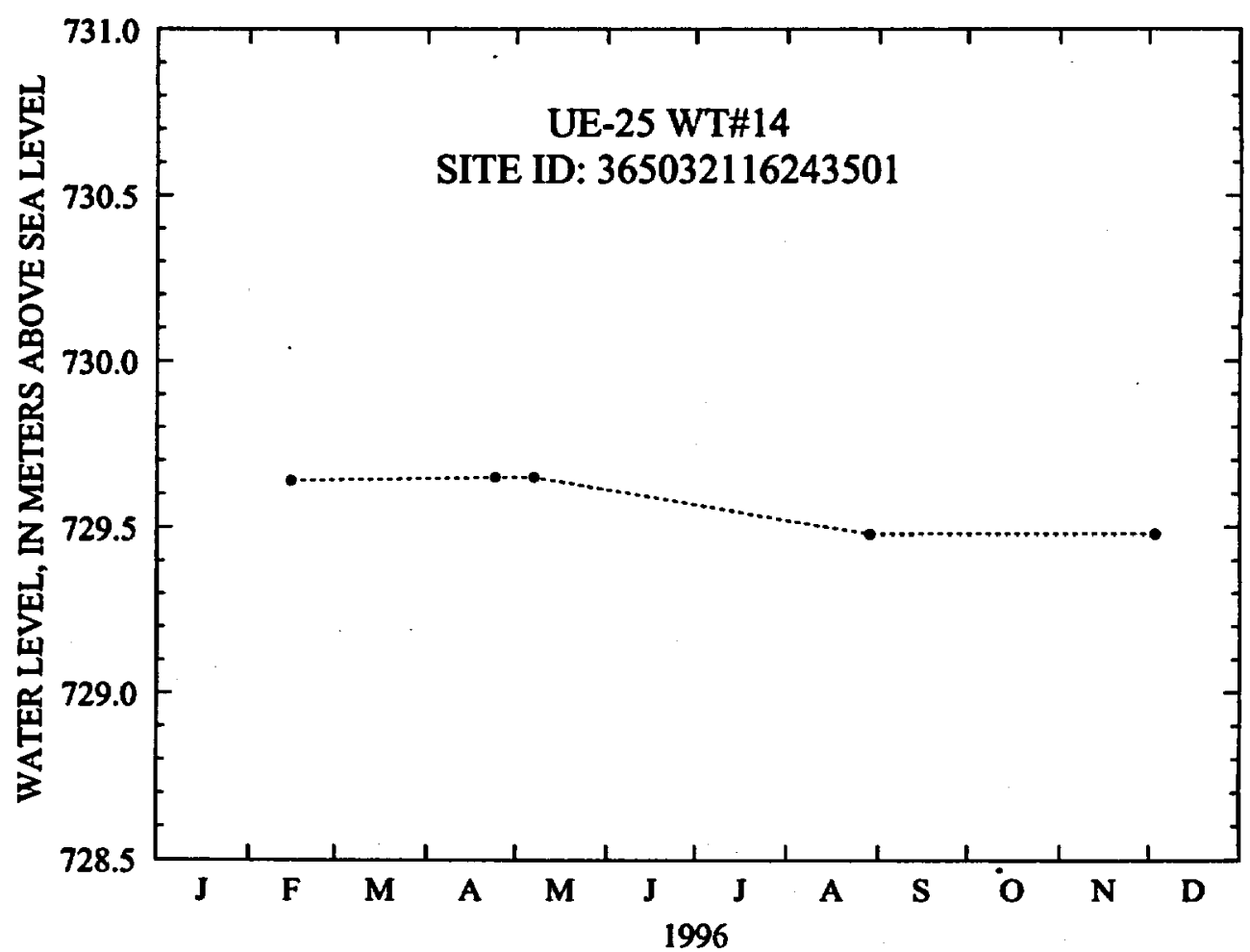

Flgure 11. Water-level altitudes, 1996, for well UE-25 WT\#14. 


\section{Well UE-25 WT\#15}

Information about the history of well UE-25 WT\#15 and about previous data from the well was obtained from various sources. These sources are: Robison (1984); J.H. Robison (U.S. Geological Survey, written commun., 1986); Robison and others (1988); Holmes \& Narver, Inc. (written commun., 1986); and Fenix \& Scisson, Inc. (1986a, 1987c).

Well specifications

1. Location and identification:

Latitude and longitude: $36^{\circ} 51^{\prime} 16^{\prime \prime} \mathrm{N}$;; $116^{\circ} 23^{\prime} 38^{\prime \prime} \mathrm{W}$.

Nevada State Central Zone Coordinates (m): N 233,512; E 176,725.

U.S. Geological Survey Site ID: 365116116233801.

2. Drilling and casing information:

Well started: November 12, 1983.

Well completed: November 22, 1983.

Drilling method: Rotary, using rock bits and air-foam circulating medium; core obtained from bottom of the borehole.

Bit diameter below water level: $222 \mathrm{~mm}$.

Casing: Surface casing only, to a depth of $38.7 \mathrm{~m}$.

Total drilled depth: $415 \mathrm{~m}$.

3. Access to and description of depth interval for measuring water levels:

62-mm-inside-diameter tubing that has a 3.7-m-long well screen on the bottom; tubing and attached screen extend from land surface to a depth of $406.9 \mathrm{~m}$; saturated interval of the borehole is within the Topopah Spring Tuff of the Paintbrush Group.

4. Information for calculating water-level altitude:

Reference point: Top of metal tag on well casing, altitude $1,082.94 \mathrm{~m}$ (surveyed by

U.S. Geological Survey in 1984).

Measuring point: Top of access tube, $0.314 \mathrm{~m}$ above reference point.

Depth correction for borehole deviation from vertical: $0.189 \mathrm{~m}$, based on approximate depth to water of $354 \mathrm{~m}$ (1990 data).

Well UE-25 WT\#15 was measured periodically during 1996, and water-level altitudes ranged from 729.08 to $729.26 \mathrm{~m}$ above sea level in 1996. The mean water-level altitude of the 1996 data was $729.18 \mathrm{~m}$ above sea level. This mean altitude was $0.09 \mathrm{~m}$ lower than the mean altitude of $729.27 \mathrm{~m}$ for 1995 (Graves and Goemaat, 1998) and $0.04 \mathrm{~m}$ lower than the mean altitude of $729.22 \mathrm{~m}$ for 1985-95 (Graves and others, 1997). The measured waterlevel altitudes are listed in table 15 and shown in figure 12. It is suspected that the pumpage at the C-hole complex may be the reason for the lower water levels in well UE-25 WT\#15. 
Table 15. Measured water-level altitudes, 1996, for well UE-25 WT\#15

\begin{tabular}{ccc}
\hline Date & $\begin{array}{c}\text { Measured water-level altitude } \\
\text { (meters above sea level) }\end{array}$ & Method of measuring water level \\
\hline $02-15-96$ & 729.20 & Chain \#3 \\
$05-28-96$ & 729.21 & Chain \#3 \\
$06-26-96$ & 729.26 & Chain \#3 \\
$07-18-96$ & 729.21 & Chain \#3 \\
$08-15-96$ & 729.20 & Chain \#3 \\
$09-18-96$ & 729.16 & Chain \#3 \\
$10-21-96$ & 729.08 & Chain \#3 \\
$11-06-96$ & 729.15 & Chain \#3 \\
$12-10-96$ & 729.15 & Chain \#3 \\
\hline
\end{tabular}

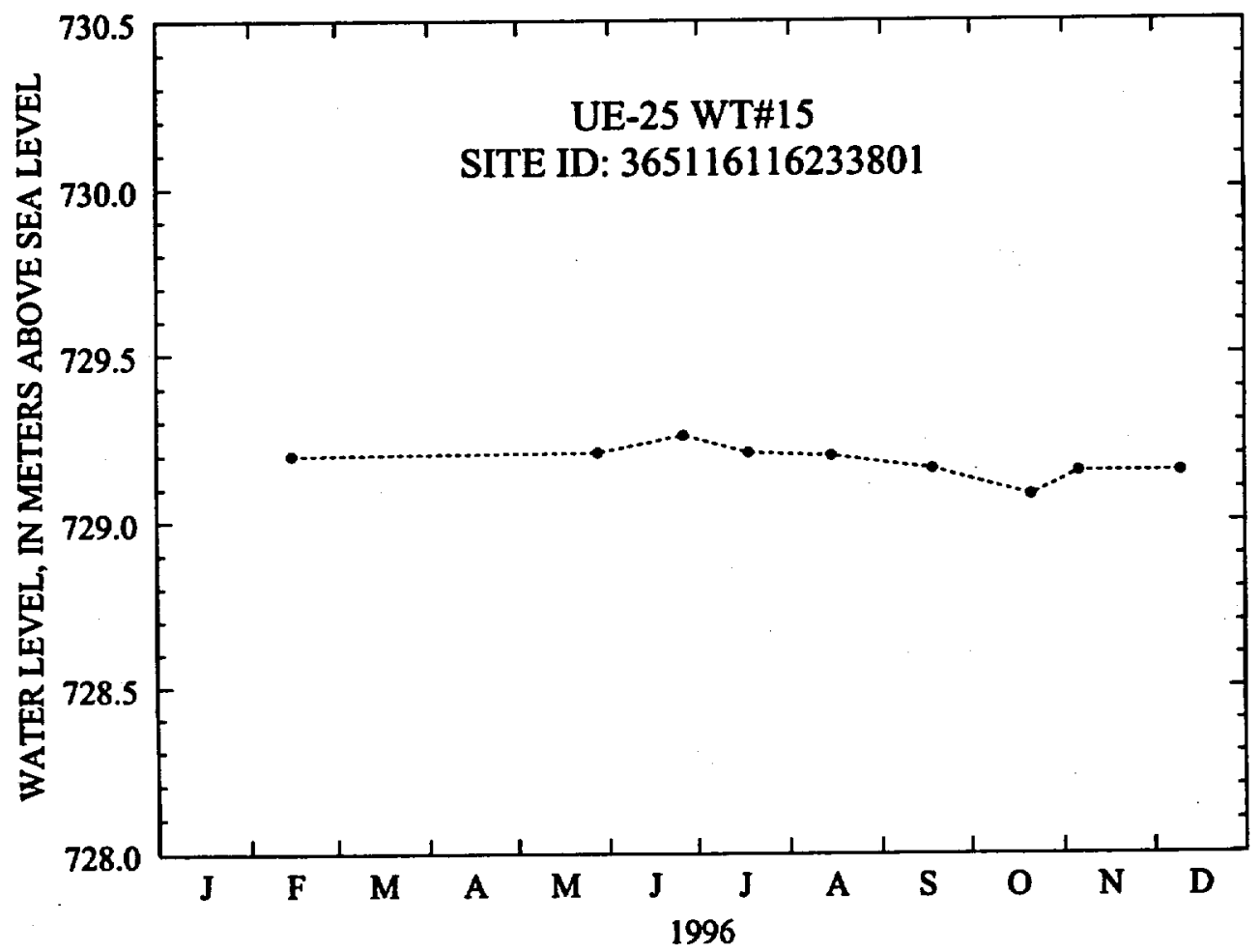

Figure 12. Water-level altitudes, 1996, for well UE-25 WT\#15. 


\section{Well UE-25 WT\#16}

Information about the history of well UE-25 WT\#16 and about previous data from the well was obtained from various sources. These sources are: Robison (1984); J.H. Robison (U.S. Geological Survey, written commun., 1986); Robison and others (1988); and Fenix \& Scisson, Inc. (1986a, 1987c).

Well specifications

\section{Location and identification:}

Latitude and longitude: $36^{\circ} 52^{\prime} 39^{\prime \prime N}$.; $116^{\circ} 25^{\prime} 34^{\prime \prime} \mathrm{W}$.

Nevada State Central Zone Coordinates (m): N 236,043; E 173,856.

U.S. Geological Survey Site ID: 365239116253401.

2. Drilling and casing information:

Well started: November 2, 1983.

Well completed: November 10, 1983.

Drilling method: Rotary, using rock bits and air-foam circulating medium; core obtained from bottom of the core hole.

Bit diameter below water level: $222 \mathrm{~mm}$.

Casing: Surface casing only, to a depth of $31 \mathrm{~m}$.

Total drilled depth: $521 \mathrm{~m}$.

3. Access to and description of depth interval for measuring water levels:

62-mm-inside-diameter tubing that has a 3.6-m-long well screen on bottom, extending from land surface to a depth of $514 \mathrm{~m}$; saturated interval of borehole is within the Calico Hills Formation.

4. Information for calculating water-level altitude:

Reference point: Top of metal tag on well casing; altitude $1,210.63 \mathrm{~m}$ (surveyed by

U.S. Geological Survey in 1984).

Measuring point: Top of access tube, $0.314 \mathrm{~m}$ above reference point.

Depth correction for borehole deviation from vertical: $0.064 \mathrm{~m}$, based on approximate depth to water of $473 \mathrm{~m}$ (1990 data).

Well UE-25 WT\#16 was measured periodically during 1996, and water-level altitudes ranged from 738.15 to $738.26 \mathrm{~m}$ above sea level in 1996 . The mean water-level altitude of the 1996 data was $738.21 \mathrm{~m}$ above sea level. This mean altitude was $0.09 \mathrm{~m}$ lower than the mean altitude of $738.30 \mathrm{~m}$ for 1995 (Graves and Goemaat, 1998) and $0.06 \mathrm{~m}$ lower than the mean altitude of $738.27 \mathrm{~m}$ for 1985-95 (Graves and others, 1997). The measured waterlevel altitudes are listed in table 16 and shown in figure 13. 
Table 16. Measured water-level altitudes, 1996, for well UE-25 WT\#16

\begin{tabular}{ccc}
\hline Date & $\begin{array}{c}\text { Measured water-tevel altitude } \\
\text { (meters above sea level) }\end{array}$ & Method of measuring water level \\
\hline $02-15-96$ & 738.24 & Chain \#3 \\
$05-22-96$ & 738.23 & Chain \#3 \\
$06-12-96$ & 738.26 & $2,800-$ foot reference steel tape \\
$06-26-96$ & 738.23 & Chain \#3 \\
$07-18-96$ & 738.20 & Chain \#3 \\
$07-24-96$ & 738.22 & $2,800-$ foot reference steel tape \\
$08-22-96$ & 738.21 & $2,800-$ foot reference steel tape \\
$09-09-96$ & 738.21 & $2,800-$ foot reference steel tape \\
$10-15-96$ & $738: 15$ & Chain \#3 \\
$11-05-96$ & 738.15 & Chain \#3 \\
$12-09-96$ & 738.16 & Chain \#3 \\
\hline
\end{tabular}

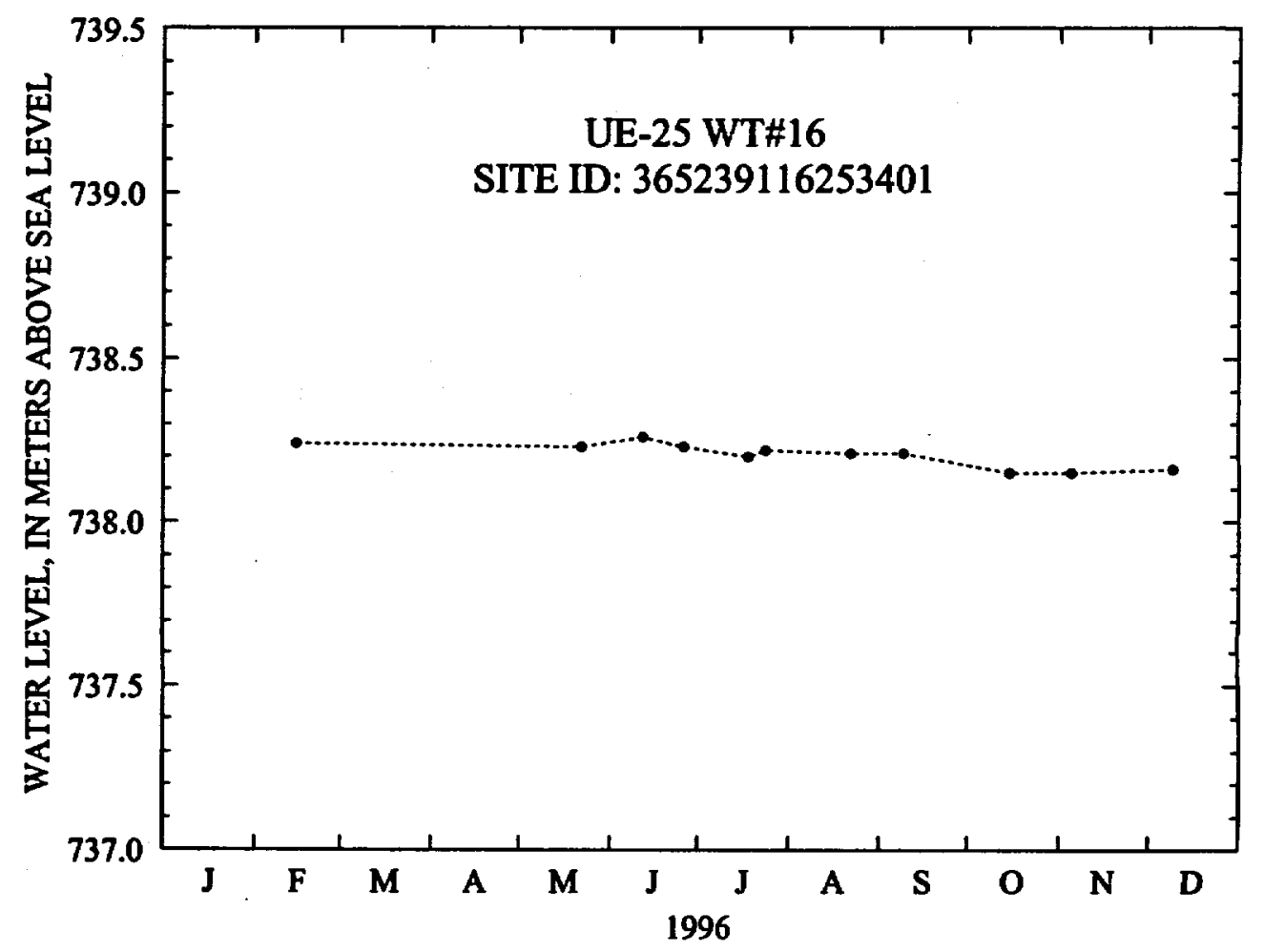

Figure 13. Water-level altitudes, 1996, for well UE-25 WT\#16. 


\section{Well UE-25 b\#1}

Information about the history of well UE-25 b\#1 and about previous data from the well was obtained from various sources. These sources are: Lobmeyer and others (1983); Lahoud and others (1984); Robison (1984); J.H. Robison (U.S. Geological Survey, written commun., 1986); Robison and others (1988); and Fenix \& Scisson, Inc. (1986b, 1987c).

Well specifications

1. Location and identification:

Latitude and longitude: $36^{\circ} 51^{\prime} 08^{\prime \prime} \mathrm{N}$.; $116^{\circ} 26^{\prime} 23^{\prime \prime} \mathrm{W}$.

Nevada State Central Zone Coordinates (m): N 233,246; E 172,644.

U.S. Geological Survey Site ID: 365108116262301 .

2. Drilling and casing information:

Well started: April 3, 1981.

Well completed: September 22, 1981.

Drilling method: Rotary, using rock bits and air-foam circulating medium; cores obtained from selected intervals.

Bit diameter below water level: $311 \mathrm{~mm}$ to $520 \mathrm{~m} ; 222 \mathrm{~mm}$ to $650 \mathrm{~m} ; 216 \mathrm{~mm}$ from 650 to $1,220 \mathrm{~m}$.

Casing extending below water level: $226-\mathrm{mm}$ inside diameter to $518 \mathrm{~m}$; casing string is tack cemented in and perforated below the water level.

Total drilled depth: $1,220 \mathrm{~m}$.

3. Access to and description of depth interval for measuring water levels:

Upper interval:

48-mm-inside-diameter tubing, open ended, to depth of about $488 \mathrm{~m}$; upper interval of borehole, from near water table to top of inflatable packer, is within the Calico Hills Formation and the Prow Pass, Bullfrog, and upper Tram Tuffs of the Crater Flat Group;

Lower interval:

62-mm-inside-diameter tubing that has an inflatable packer on bottom end, to depth of $1,199 \mathrm{~m}$; lower interval of borehole, from below packer to bottom of well, is within the lower Tram Tuff of the Crater Flat Group and Lithic Ridge Tuff.

4. Information for calculating water-level altitude:

Reference point: Top of metal tag on well casing; altitude $1,200.73 \mathrm{~m}$ (surveyed by

U.S. Geological Survey in 1984).

Measuring point: Top of access tubes, $0.302 \mathrm{~m}$ above reference point, upper interval; $0.134 \mathrm{~m}$ above reference point, lower interval.

Depth correction for borehole deviation from vertical: $0.244 \mathrm{~m}$, based on approximate depth to water of $470 \mathrm{~m}$ (1990 data).

\section{Other information:}

Water-level measurements for 1996 were made only in the upper interval of borehole UE-25 b\#1.

Well UE-25 b\#1, upper interval was measured periodically during 1996, and water-level altitudes ranged from 730.31 to $730.60 \mathrm{~m}$ above sea level in 1996 . The mean water-level altitude of the 1996 data was $730.44 \mathrm{~m}$ above sea level. This mean altitude was $0.17 \mathrm{~m}$ lower than the mean altitude of $730.61 \mathrm{~m}$ for 1995 (Graves and Goemaat, 1998) and $0.21 \mathrm{~m}$ lower than the mean altitude of $730.65 \mathrm{~m}$ for $1985-95$ (Graves and others, 1997). The measured water-level altitudes are listed in table 17 and shown in figure 14. The lower water levels in well 
UE-25 b\#l, upper interval, are believed to be due to the pumpage at the C-hole complex that began on May 8, 1996. Through December 31, 1996, an estimated 196 million liters was pumped from well UE-25 c\#3. 1

Table 17. Measured water-level altitudes, 1996, for well UE-25 b\#1, upper interval

\begin{tabular}{ccc}
\hline Date & $\begin{array}{c}\text { Measured water-level aifltude } \\
\text { (meters above sea level) }\end{array}$ & Method of measuring water level \\
\hline $02-21-96$ & 730.60 & Chain \#3 \\
$05-23-96$ & 730.59 & Chain \#3 \\
$06-25-96$ & 730.50 & Chain \#3 \\
$07-15-96$ & 730.45 & Chain \#3 \\
$08-14-96$ & 730.41 & Chain \#3 \\
$09-19-96$ & 730.38 & Chain \#3 \\
$10-22-96$ & 730.32 & Chain \#3 \\
$11-05-96$ & 730.31 & Chain \#3 \\
$12-10-96$ & 730.41 & Chain \#3 \\
\hline
\end{tabular}

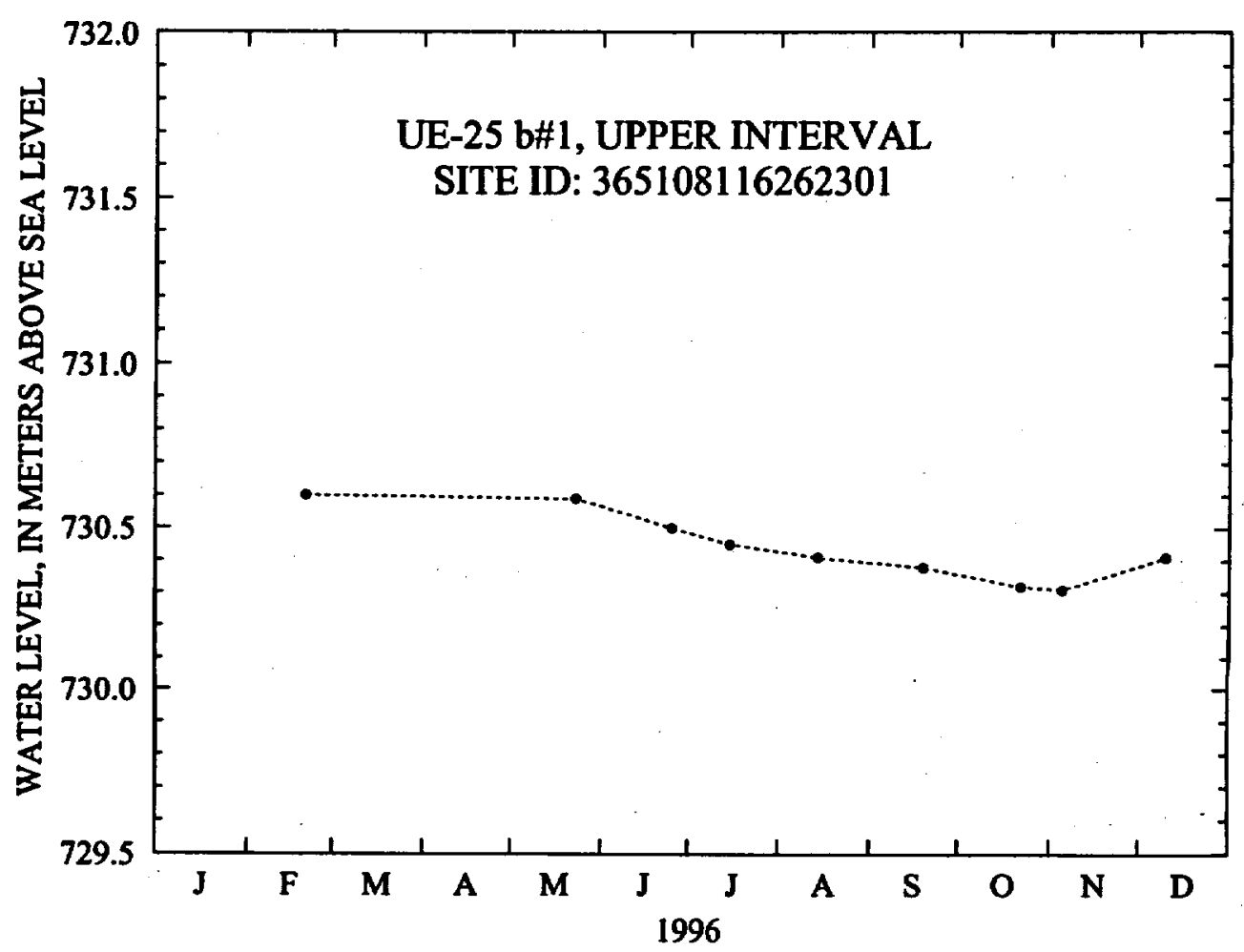

Figure 14. Water-level altitudes, 1996, for well UE-25 b\#1, upper interval. 


\section{Well UE-25 p\#1}

Information about the history of well UE-25 $\mathrm{p \# l}$ and about previous data from the well was obtained from various sources. These sources are: Craig and Johnson (1984); Craig and Robison (1984); Robison (1984); J.H. Robison (U.S. Geological Survey, written commun., 1986); Robison and others (1988); and Fenix \& Scisson, Inc. $(1986 \mathrm{c}, 1987 \mathrm{c})$.

Well specifications

1. Location and identification:

Latitude and longitude: $36^{\circ} 49^{\prime} 38^{\prime \prime} \mathrm{N}$.; $116^{\circ} 25^{\prime} 21^{\prime \prime} \mathrm{W}$.

Nevada State Central Zone Coordinates (m): N 230,481; E 174,188.

U.S. Geological Survey Site ID: 364938116252102.

2. Drilling and casing information:

Well started: November 13, 1982.

Well completed: May 24, 1983.

Drilling method: Rotary, using rock bits and air-foam circulating medium; cores obtained from selected intervals.

Bit diameter below water level: $375 \mathrm{~mm}$ to $487 \mathrm{~m} ; 251 \mathrm{~mm}$ from 487 to $1,304 \mathrm{~m} ; 17 \mathrm{~mm}$ from 1,304 to $1,317 \mathrm{~m} ; 171 \mathrm{~mm}$ from 1,317 to $1,798 \mathrm{~m} ; 156 \mathrm{~mm}$ from 1,798 to $1,805 \mathrm{~m}$.

Casing extending below water level: $255-\mathrm{mm}$ inside diameter from land surface to $477 \mathrm{~m} ; 177-\mathrm{mm}$ inside diameter from 453 to $1,297 \mathrm{~m}$; casing string is cemented in, has no perforations.

Total drilled depth: $1,805 \mathrm{~m}$.

3. Access to and description of depth interval for measuring water levels:

38-mm-inside-diameter tubing, open end, to depth of $418 \mathrm{~m}$; well construction is such that water level of the tuffs of Tertiary age is not monitored. Only the water level in the underlying carbonate rocks of Paleozoic age is measured (Tertiary-Paleozoic contact is at $1,244 \mathrm{~m}$ ).

Note: A 38-mm-inside-diameter tubing, closed end, and filled with water, to a depth of $413 \mathrm{~m}$ below land surface also is installed in the well to allow access for temperature logging.

4. Information for calculating water-level altitude:

Reference point: Top of metal tag on well casing; altitude 1,114.21 m (surveyed by

U.S. Geological Survey in 1984).

Measuring point: Top of access tube, $0.158 \mathrm{~m}$ above reference point.

Depth correction for borehole deviation from vertical: $0.021 \mathrm{~m}$, based on approximate depth to water of $362 \mathrm{~m}$ (1990 data).

Well UE-25 p\#1 was measured hourly and periodically during 1996. Hourly measurements were made until September 3, 1996, the day hourly data collection in support of the water-level network was discontinued. ${ }^{4}$ During the period of hourly measurements, two calibrations of one transducer were performed. In addition, a calibration was completed on November 7, 1995. This calibration was used to calculate water-level altitudes at the beginning of 1996. Results of the transducer calibrations are as follows:

\footnotetext{
${ }^{4}$ Continuous hourly data collection of well UE-25 p\#1 in support of the water-level network was discontinued on September 3, 1996. However, to monitor potential drawdown in well UE-25 p\#1 due to ongoing hydraulic testing at the C-hole complex (fig. 1), data collection equipment was changed and continuous monitoring of water levels in well UE-25 p\#1 continued from September 3, 1996, through December 31, 1996.
} 


\begin{tabular}{cccccc}
\hline $\begin{array}{c}\text { Transducer } \\
\text { serial number }\end{array}$ & $\begin{array}{c}\text { Callbration } \\
\text { date }\end{array}$ & $\begin{array}{c}\text { Slope } \\
\text { (meter per } \\
\text { millivolt) }\end{array}$ & $\begin{array}{c}\text { Coefficlent of } \\
\text { determination }\end{array}$ & $\begin{array}{c}\text { Watertevel } \\
\text { altitude } \\
\text { (meters) }\end{array}$ & $\begin{array}{c}\text { Method of measuring } \\
\text { water level }\end{array}$ \\
\hline 592477 & $11-07-95$ & 0.089 & 1.000 & 752.52 & Tag with transducer \\
592477 & $05-08-96$ & .088 & 1.000 & 752.67 & Chain \#3 \\
592477 & $09-03-96$ & .087 & 1.000 & 752.67 & Chain \#3 \\
\hline
\end{tabular}

Data were not converted to water levels from May 8, 1996, through September 3, 1996, because of erratic transducer output and the uncertainty of how to apply a datum correction over this timeframe. Partial data were collected by the data-collection platform on January 10 and 11,1996 . The reason for the partial data is not known. All other transducer data collected for 1996 were considered valid.

Following the removal of the transducer, well UE-25 p\#1 was measured manually on September 3 and December 3, 1996. Daily mean water-level altitudes of the hourly data for well UE-25 p\#1 ranged from 752.58 (January 1, 1996) to $752.74 \mathrm{~m}$ (February 25, 1996) above sea level in 1996 (fig. 15). The water-level altitudes of the two manual water-level measurements are within this range. Monthly mean water-level altitudes are listed in table 18. The measured water-level altitudes are listed in table 19 . The mean water-level altitude of the 1996 data was $752.65 \mathrm{~m}$ above sea level. This mean altitude was $0.08 \mathrm{~m}$ higher than the mean altitude of $752.57 \mathrm{~m}$ for 1995 (Graves and Goemaat, 1998) and $0.21 \mathrm{~m}$ higher than the mean altitude of $752.44 \mathrm{~m}$ for 1985-95 (Graves and others, 1997).

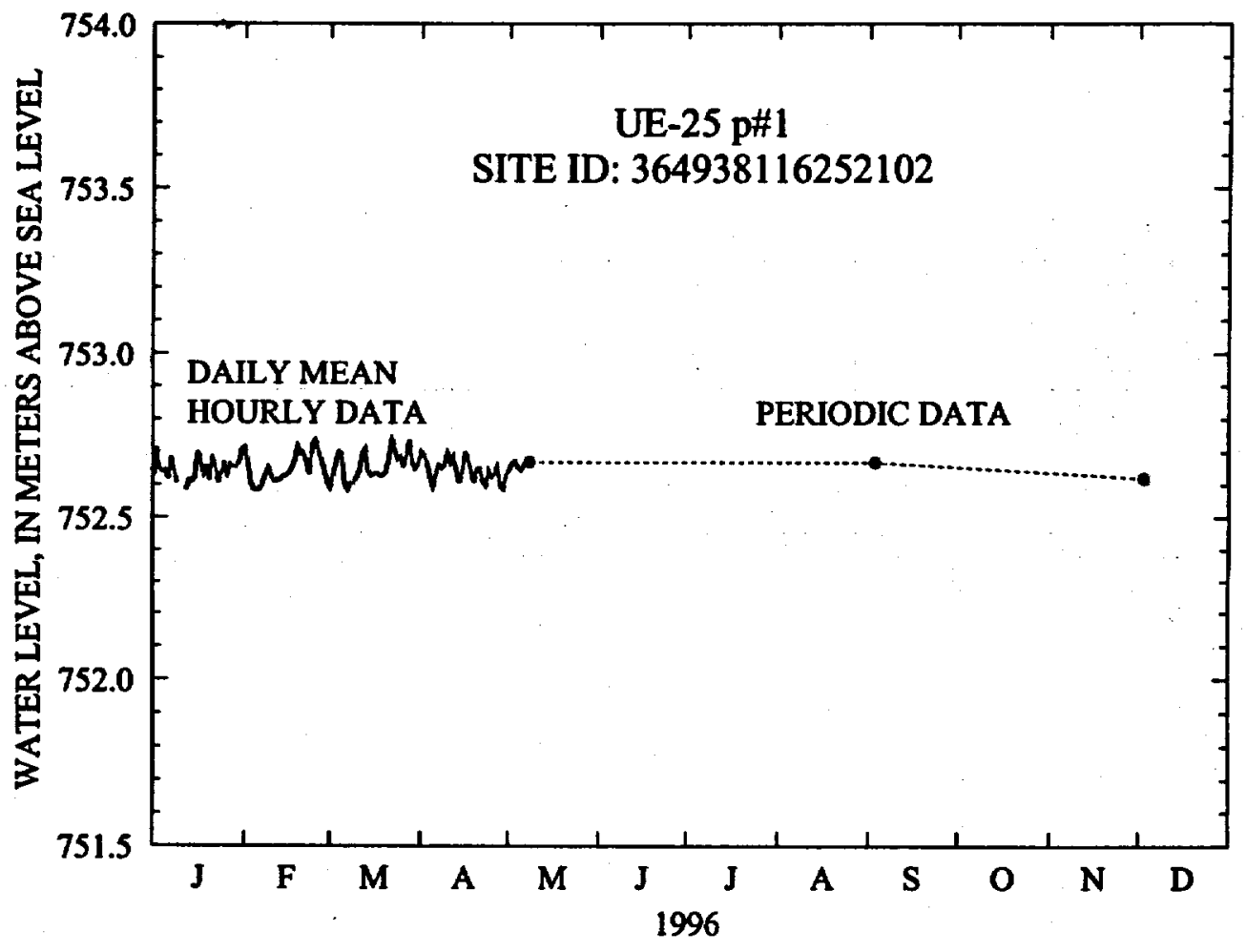

Figure 15. Water-level altitudes, 1996, for well UE-25 p\#1. 
Table 18. Monthly mean water-level altitudes, 1996, from daily mean water levels for well UE-25 p\#1.

[-, data not available; NA, not applicable, well not instrumented during this month]

\begin{tabular}{lcc}
\hline Month & $\begin{array}{c}\text { Monthly mean } \\
\text { water-level altitude } \\
\text { (meters above sea level) }\end{array}$ & $\begin{array}{c}\text { Number of missing daily } \\
\text { means }\end{array}$ \\
\hline January & 752.65 & 2 \\
February & 752.65 & 0 \\
March & 752.66 & 0 \\
April & 752.64 & 0 \\
May & 752.66 & 24 \\
June & - & 30 \\
July & - & 31 \\
August & - & 31 \\
September & - & 3 \\
October & NA & NA \\
November & NA & NA \\
December & NA & NA \\
\hline
\end{tabular}

Table 19. Measured water-level altitudes, 1996, for well UE-25 p\#1

\begin{tabular}{ccc}
\hline Date & $\begin{array}{c}\text { Measured water-level altltude } \\
\text { (meters above sea level) }\end{array}$ & Method of measuring water level \\
\hline $05-08-96$ & 752.67 & Chain \#3 \\
$09-03-96$ & 752.67 & Chain \#3 \\
$12-03-96$ & 752.62 & Chain \#3 \\
\hline
\end{tabular}




\section{Well USW VH-1}

Information about the history of well USW VH-1 and about previous data from the well was obtained from various sources. These sources are: Robison (1984); J.H. Robison (U.S. Geological Survey, written commun., 1986); Robison and others (1988); Holmes \& Narver, Inc. (written commun., 1986); and Thordarson and Howells (1987).

Well specifications

1. Location and identification:

Latitude and longitude: $36^{\circ} 47^{\prime} 32^{\prime \prime N}$.; $116^{\circ} 33^{\prime} 07^{\prime \prime} \mathrm{W}$.

Nevada State Central Zone Coordinates (m): N 226,575; E 162,649.

U.S. Geological Survey Site ID: 364732116330701.

2. Drilling and casing information:

Well started: October 28, 1980.

Well completed: February 18, 1981.

Drilling method: Rotary, using rock bits, and air-foam and polymer circulating medium.

Bit diameter below water level: $222 \mathrm{~mm}$ to $278 \mathrm{~m} ; 159 \mathrm{~mm}$ from $278 \mathrm{~m}$ to total depth.

Casing extending below water level: $177-\mathrm{mm}$ inside diameter to $278 \mathrm{~m}$.

Total drilled depth: $762 \mathrm{~m}$.

3. Access to and description of depth interval for measuring water levels:

48-mm-inside-diameter tubing, open ended from land surface to $205.4 \mathrm{~m}$; saturated interval of the well is within the Tiva Canyon and Topopah Spring Tuffs of the Paintbrush Group and the Prow Pass and Bullfrog Tuffs of the Crater Flat Group. A pump was installed in the well on July 8,1982 , at a depth of $212.8 \mathrm{~m}$.

4. Information for calculating water-level altitude:

Reference point: Top of metal tag on well casing, altitude $963.23 \mathrm{~m}$ (surveyed by Holmes \& Narver, Inc., March 3, 1986).

Measuring point: Top of access tube, $0.631 \mathrm{~m}$ above reference point.

Depth correction for borehole deviation from vertical: $0.049 \mathrm{~m}$, based on approximate depth to water of $184 \mathrm{~m}$ (1990 data).

Well USW VH-1 was measured periodically during 1996 and water-level altitudes ranged from 779.43 to $779.55 \mathrm{~m}$ above sea level in 1996 . The mean water-level altitude of the 1996 data was 779.49 $\mathrm{m}$ above sea level. This mean altitude was the same as the mean altitude of $779.49 \mathrm{~m}$ for 1995 (Graves and Goemaat, 1998), and $0.05 \mathrm{~m}$ higher than the mean altitude of $779.44 \mathrm{~m}$ for 1985-95 (Graves and others, 1997). The measured water-level altitudes are listed in table 20 and shown in figure 16. 
Table 20. Measured water-level altitudes, 1996, for well USW VH-1

\begin{tabular}{ccc}
\hline Date & $\begin{array}{c}\text { Measured water-level althude } \\
\text { (meters above sea level) }\end{array}$ & Method of measuring water level \\
\hline $02-07-96$ & 779.52 & Chain \#3 \\
$05-22-96$ & 779.49 & Chain \#3 \\
$06-11-96$ & 779.52 & $2,800-$ foot reference steel tape \\
$06-19-96$ & 779.51 & Chain \#3 \\
$07-16-96$ & 779.43 & Chain \#3 \\
$08-12-96$ & 779.50 & Chain \#3 \\
$09-17-96$ & 779.44 & Chain \#3 \\
$10-16-96$ & 779.55 & Chain \#3 \\
$11-13-96$ & 779.49 & Chain \#3 \\
$12-12-96$ & 779.47 & Chain \#3 \\
\hline
\end{tabular}

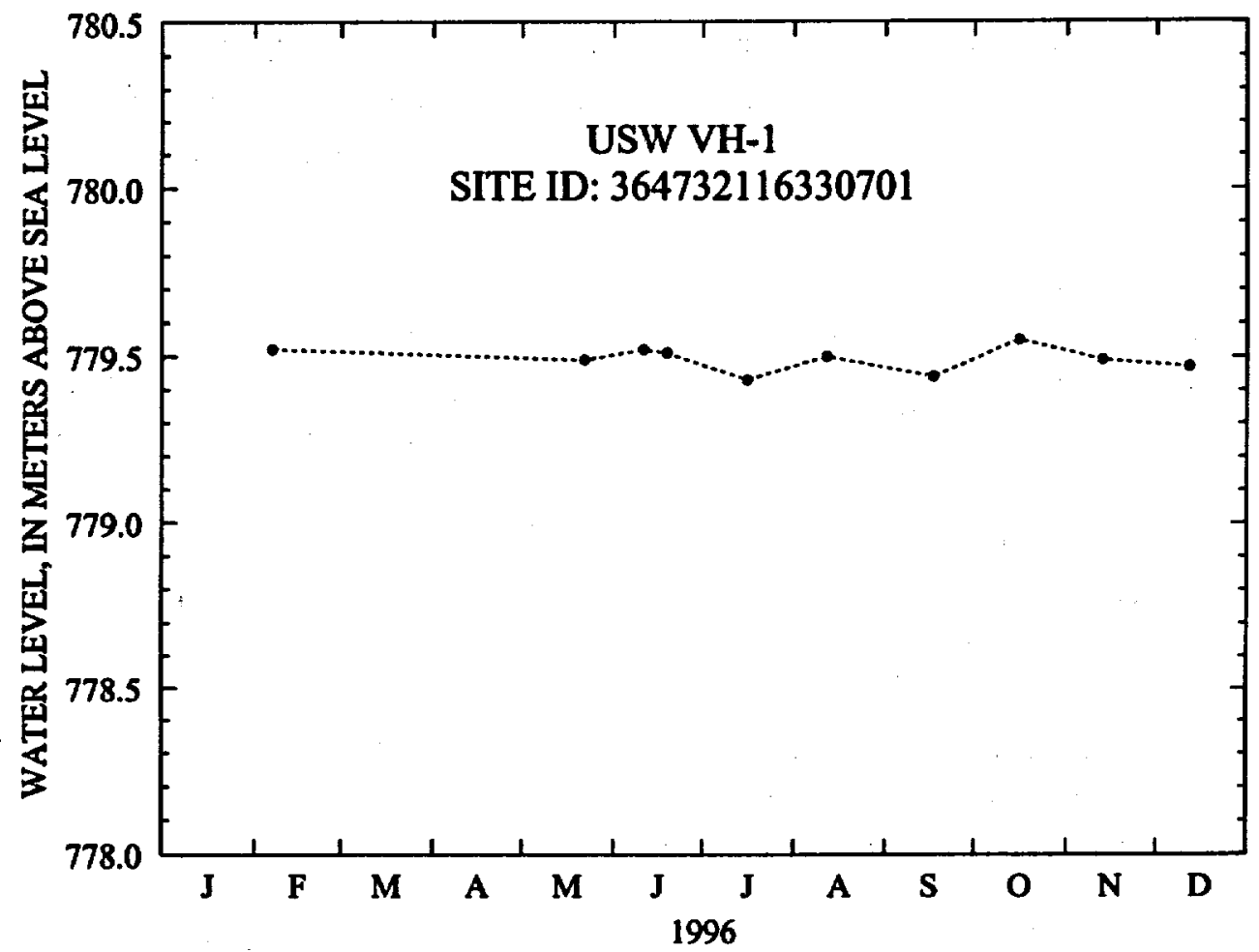

Figure 16. Water-level altitudes, 1996, for well USW VH-1. 


\section{Well USW G-2}

Information about the history of well USW G-2 and about previous data from the well was obtained from various sources. These sources are: Maldonado and Koether (1983); Robison (1984); J.H. Robison (U.S. Geological Survey, written commun., 1986); Robison and others (1988); Holmes \& Narver, Inc. (written commun., 1986); Fenix \& Scisson, Inc. (1987b, 1987c); and Nelson and Schimschal (1993).

Well specifications

\section{Location and identification:}

Latitude and longitude: $36^{\circ} 53^{\prime} 22^{\prime \prime} \mathrm{N}$; $116^{\circ} 27^{\prime} 35^{\prime \prime} \mathrm{W}$.

Nevada State Central Zone Coordinates (m): N 237,386; E 170,842.

U.S. Geological Survey Site ID: 365322116273501.

2. Drilling and casing information:

Well started: March 25, 1981.

Well completed: October 24, 1981.

Drilling method: Rotary, using rock bits, with polymer mud to $88 \mathrm{~m}$; cored and reamed from $88 \mathrm{~m}$ to total depth; polymer mud and air foam used as needed to total depth.

Bit diameter below water level: $222 \mathrm{~mm}$ to $814 \mathrm{~m} ; 159 \mathrm{~mm}$ from $814 \mathrm{~m}$ to $947 \mathrm{~m}$;

$156 \mathrm{~mm}$ from 947 to $1,439 \mathrm{~m} ; 76 \mathrm{~mm}$ from $1,439 \mathrm{~m}$ to total depth.

Casing extending below water level: None (surface casing, 320-mm inside diameter, 0-85 $\mathrm{m}$, and 276-mm inside diameter, 0-242 m).

Total drilled depth: $1,831 \mathrm{~m}$.

3. Access to and description of depth interval for measuring water levels:

Saturated interval of borehole is within the Topopah Spring Tuff of the Paintbrush Group; the Calico Hills Formation; Prow Pass, Bullfrog, and Tram Tuffs of the Crater Flat Group; Lithic Ridge Tuff; and older flows and tuffs.

Bridge plug at depth of $806 \mathrm{~m}$. Second bridge plug installed in well on September 29, 1995; top at depth of $792 \mathrm{~m}$.

Until October 1995, measurements were made through the well casing. On October 3, 1995, a 62-mm-inside-diameter tubing extending from land surface to $597 \mathrm{~m}$ was installed in well. The bottom of the tube is capped with a 1.5-m-long well screen above the cap.

4. Information for calculating water-level altitude:

Reference point: Top of metal tag on well casing, altitude $1,553.86 \mathrm{~m}$ (surveyed by . U.S. Geological Survey in 1984). 
Measuring point: (All measuring points above reference point) Top of casing, $0.034 \mathrm{~m}$ before February 3 , 1993, $0.332 \mathrm{~m}$ February 3, 1993, to October 1, 1995. Monitoring tube placed in well on October 3, 1995. Measuring point changed to top of monitoring tube. Measuring point from October 2, 1995 to January 1, $1996,0.20 \mathrm{~m}$. Tube moved in well during early January 1996; measuring point after January 10, 1996, $0.56 \mathrm{~m}$.

Depth correction for borehole deviation from vertical: $0.192 \mathrm{~m}$, based on approximate depth to water of 534 m (1994 data).

5. During 1996 a pump was installed in well USW G-2 for hydraulic testing and the well was pumped as follows (G.M. O'Brien, U.S. Geological Survey, written commun., 1998):

\begin{tabular}{|c|c|c|c|}
\hline $\begin{array}{l}\text { Date and time pump on or } \\
\text { off }\end{array}$ & $\begin{array}{l}\text { Duration of pumpling } \\
\text { (hours) }\end{array}$ & $\begin{array}{l}\text { Mean discharge } \\
\text { (liters per second) }\end{array}$ & $\begin{array}{l}\text { Total dlscharge } \\
\text { (ilters) }\end{array}$ \\
\hline $\begin{array}{l}\text { Pump turned on and off these } \\
\text { days: } \\
01 / 17 / 96 \\
01 / 18 / 96 \\
01 / 30 / 96 \text { through } \\
02 / 02 / 96\end{array}$ & $\begin{array}{l}\text { Well pumped for a total of } \\
\text { approximately } 24.5 \text { hours dur- } \\
\text { ing these days. }\end{array}$ & $\begin{array}{l}\text { Discharge varied throughout } \\
\text { pumping interval; mean dis- } \\
\text { charge was not determined. }\end{array}$ & $\begin{array}{l}\text { Due to varying discharge } \\
\text { rates, total discharge was not } \\
\text { determined. }\end{array}$ \\
\hline $\begin{array}{l}\text { On: 02/06/96,@09:15 } \\
\text { Off: 02/08/96,@16:06 }\end{array}$ & 54.9 & 3.66 & 720,000 \\
\hline $\begin{array}{l}\text { On: 04/08/96,@09:00 } \\
\text { Off: 04/25/96,@09:00 }\end{array}$ & 408 & 3.60 & $5,300,000$ \\
\hline
\end{tabular}

Well USW G-2 was measured periodically ${ }^{5}$ during 1996 and water-level altitudes for well USW G-2 ranged from $1,015.61$ to $1,019.81 \mathrm{~m}$ above sea level in 1996. However, the lowest water-level altitude due to pumpage during 1996 was approximately $982 \mathrm{~m}$ (on April 25, 1996) (G.M. O’Brien, U.S. Geological Survey, written commun., 1998). A mean water-level altitude of the 1996 water-level data for USW G-2 was not determined because some water-level measurements do not represent natural, undisturbed, conditions. The measured waterlevel altitudes are listed in table 21 and shown in figure 17.

Table 21. Measured water-level altitudes, 1996, for well USW G-2

\begin{tabular}{ccc}
\hline Date & $\begin{array}{c}\text { Measured water-level altitude } \\
\text { (meters above sea level) }\end{array}$ & Method of measuring water level \\
\hline $01-17-96$ & $1,019.81$ & Chain \#3 \\
$06-03-96$ & $1,015.61$ & Chain \#3 \\
$08-26-96$ & $1,019.05$ & Chain \#3 \\
$12-17-96$ & $1,019.21$ & Chain \#3 \\
\hline
\end{tabular}

${ }^{5}$ Well USW G-2 was monitored continuously before, during, and after the hydraulic tests. 


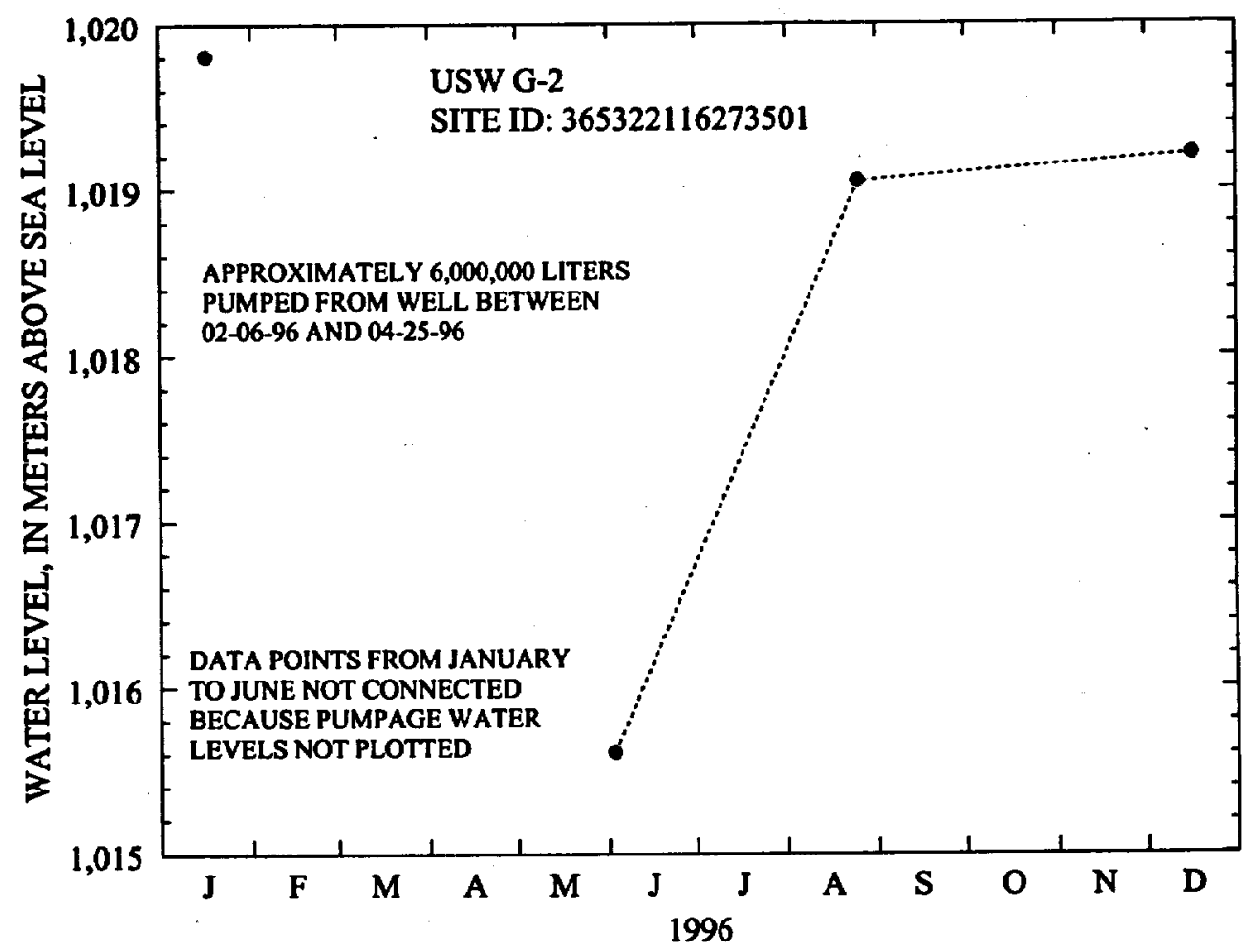

Figure 17. Water-level altitudes, 1996, for well USW G-2. 


\section{Well USW H-1}

Information about the history of well USW H-1 and about previous data from the well was obtained from various sources. These sources are: Rush and others (1983); Rush and others (1984); Robison (1984);

J.H. Robison (U.S. Geological Survey, written commun., 1986); Robison and others (1988); and Fenix \& Scisson, Inc. (1987a, 1987c).

Well specifications

1. Location and identification:

Latitude and longitude: $36^{\circ} 51^{\prime} 57^{\prime \prime} \mathrm{N}$.; $116^{\circ} 27^{\prime} 12^{\prime \prime} \mathrm{W}$.

Nevada State Central Zone Coordinates (m): N 234,774; E 171,416.

U.S. Geological Survey Site ID: 365157116271201.

2. Drilling and casing information:

Well started: September 3, 1980.

Well completed: January 25, 1981 (borehole completion, including geophysical logging and hydraulic testing); July 6, 1982 (workover of borehole; four piezometers installed).

Drilling method: Rotary, using rock bits and air-foam circulating medium; cores obtained from selected intervals.

Bit diameter below water level: $311 \mathrm{~mm}$ to $688 \mathrm{~m} ; 222 \mathrm{~mm}$ from $688 \mathrm{~m}$ to $1,829 \mathrm{~m}$.

Casing extending below water level: $226-\mathrm{mm}$ inside diameter to $687 \mathrm{~m}$. Casing string is tack cemented and perforated below the water table. See section 3 for description of intervals open to water.

Total drilled depth: $1,829 \mathrm{~m}$.

3. Access to and description of depth interval for measuring water levels:

Tube 1:

44-mm inside diameter that has a 3.6-m-long well screen on bottom, extending from land surface to depth of $1,806 \mathrm{~m}$; responds to depth interval from 1,783 to $1,814 \mathrm{~m}$ within older flows and tuffs beneath the Lithic Ridge Tuff;

Tube 2:

44-mm inside diameter that has a 3.6-m-long well screen on bottom, extending from land surface to depth of $1,115 \mathrm{~m}$; responds to depth interval from 1,097 to $1,123 \mathrm{~m}$ within the Tram Tuff of the Crater Flat Group and lava flow and flow breccia beneath the Tram Tuff;

Tube 3:

44-mm inside diameter that has a 3.6-m-long well screen on bottom, extending from land surface to depth of $741 \mathrm{~m}$; responds to depth interval from 716 to $765 \mathrm{~m}$ within the Bullfrog Tuff of the Crater Flat Group;

Tube 4:

62-mm inside diameter, open ended, extending from land surface to depth of $640 \mathrm{~m}$; responds to depth interval from 572 to $673 \mathrm{~m}$ within the Prow Pass Tuff of the Crater Flat Group. 
Note: During the 1982 borehole workover, a gravel pack was placed in the vicinity of the well screens for tubes 1,2 , and 3; other intervals were grouted with cement to ensure that the piezometers are hydraulically isolated from each other.

4. Information for calculating water-level altitude:

Reference point: Top of metal tag on well casing; altitude $1,303.10 \mathrm{~m}$ (surveyed by U.S. Geological Survey in 1984).

Measuring point: Top of access tubes, $0.311 \mathrm{~m}$ above reference point, all intervals.

Depth correction for borehole deviation from vertical: $0.143 \mathrm{~m}$ in tube 1 , based on approximate depth to water of $518 \mathrm{~m}$ (1990 data); $0.171 \mathrm{~m}$ in tube 2, based on approximate depth to water of $567 \mathrm{~m}$ (1993 data); $0.174 \mathrm{~m}$ in tubes 3 and 4, based on approximate depths to water of $572 \mathrm{~m}$ (1990 data).

Tube 1:

Well USW H-1, tube 1 was measured periodically during 1996, and water-level altitudes ranged from 785.88 to $786.12 \mathrm{~m}$ above sea level in 1996. The mean water-level altitude of the 1996 data was $786.00 \mathrm{~m}$ above sea level. This mean altitude was $0.03 \mathrm{~m}$ higher than the mean altitude of $785.97 \mathrm{~m}$ for 1995 (Graves and Goemaat, 1998) and $0.51 \mathrm{~m}$ higher than the mean altitude of $785.49 \mathrm{~m}$ for 1985-95 (Graves and others, 1997). The measured water-level altitudes are listed in table 22 and shown in figure 18.

As mentioned for well USW WT-10, each tube monitored for USW $\mathrm{H}-1$ had a sudden rise in water level during June 1996. In tube 1, the rise from May to June 1996 was about $0.23 \mathrm{~m}$. In comparing tube 1 to the other wells where the water-level rise was observed, one difference is noted: the water level never declined back to the May water level.

Table 22. Measured water-level altitudes, 1996, for well USW H-1, tube 1

\begin{tabular}{ccc}
\hline Date & $\begin{array}{c}\text { Measured waterfevel altitude } \\
\text { (meters above sea level) }\end{array}$ & Method of measuring water level \\
\hline $02-22-96$ & 785.88 & Chain \#3 \\
$05-28-96$ & 785.88 & Chain \#3 \\
$06-27-96$ & 786.11 & Chain \#3 \\
$07-15-96$ & 786.02 & Chain \#3 \\
$08-13-96$ & 785.97 & Chain \#3 \\
$09-19-96$ & 785.93 & Chain \#3 \\
$10-22-96$ & 786.12 & Chain \#3 \\
$11-07-96$ & 786.04 & Chain \#3 \\
$12-10-96$ & 786.06 & Chain \#3 \\
\hline
\end{tabular}




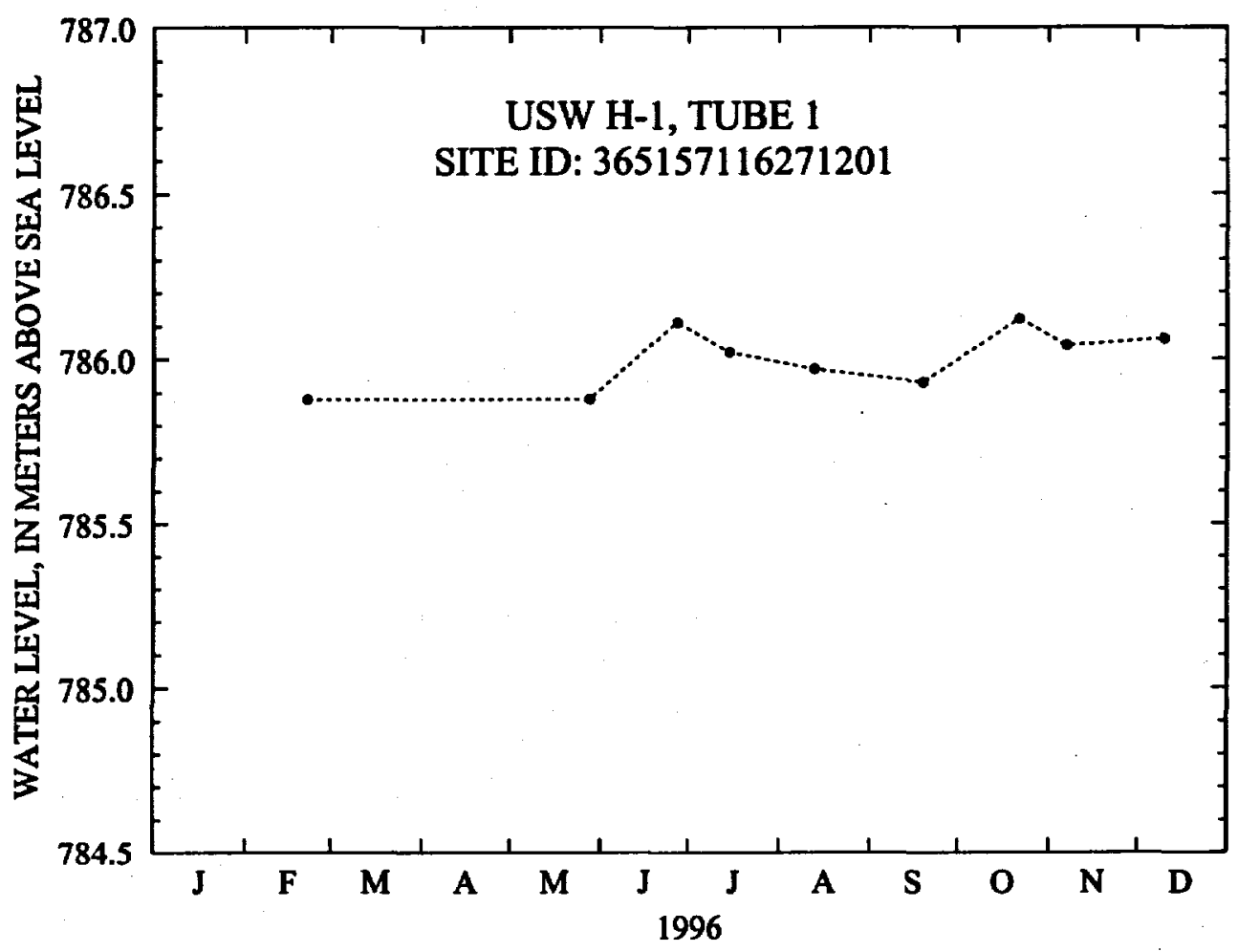

Figure 18. Water-level altitudes, 1996, for well USW H-1, tube 1.

Tube 2:

Well USW H-1, tube 2, was measured periodically during 1996, and water-level altitudes ranged from 735.43 to $735.82 \mathrm{~m}$ above sea level in 1996 . The mean water-level altitude of the 1996 data was $735.55 \mathrm{~m}$ above sea level. This mean altitude was $0.19 \mathrm{~m}$ lower than the mean altitude of $735.74 \mathrm{~m}$ for 1995 (Graves and Goemaat, 1998) and $0.42 \mathrm{~m}$ lower than the mean altitude of $735.97 \mathrm{~m}$ for 1985-95 (Graves and others, 1997).

As mentioned for well USW WT-10, each tube monitored for USW H-1 had a sudden rise in water level during June 1996. In tube 2, the rise from May to June 1996 was about $0.22 \mathrm{~m}$. By July 1996, the water level in tube 2 declined back to a water level slightly lower than the May water level.

Table 23. Measured water-level altitudes, 1996, for well USW H-1, tube 2

\begin{tabular}{ccc}
\hline Date & $\begin{array}{c}\text { Measured water-level altitude } \\
\text { (meters above sea level) }\end{array}$ & Method of measuring water level \\
\hline $02-22-96$ & 735.60 & Chain \#3 \\
$05-28-96$ & 735.60 & Chain \#3 \\
$06-27-96$ & 735.82 & Chain \#3 \\
$07-15-96$ & 735.56 & Chain \#3 \\
$08-13-96$ & 735.51 & Chain \#3 \\
$09-19-96$ & 735.48 & Chain \#3 \\
$10-22-96$ & 735.55 & Chain \#3 \\
$11-07-96$ & 735.44 & Chain \#3 \\
$12-10-96$ & 735.43 & Chain \#3 \\
\hline
\end{tabular}




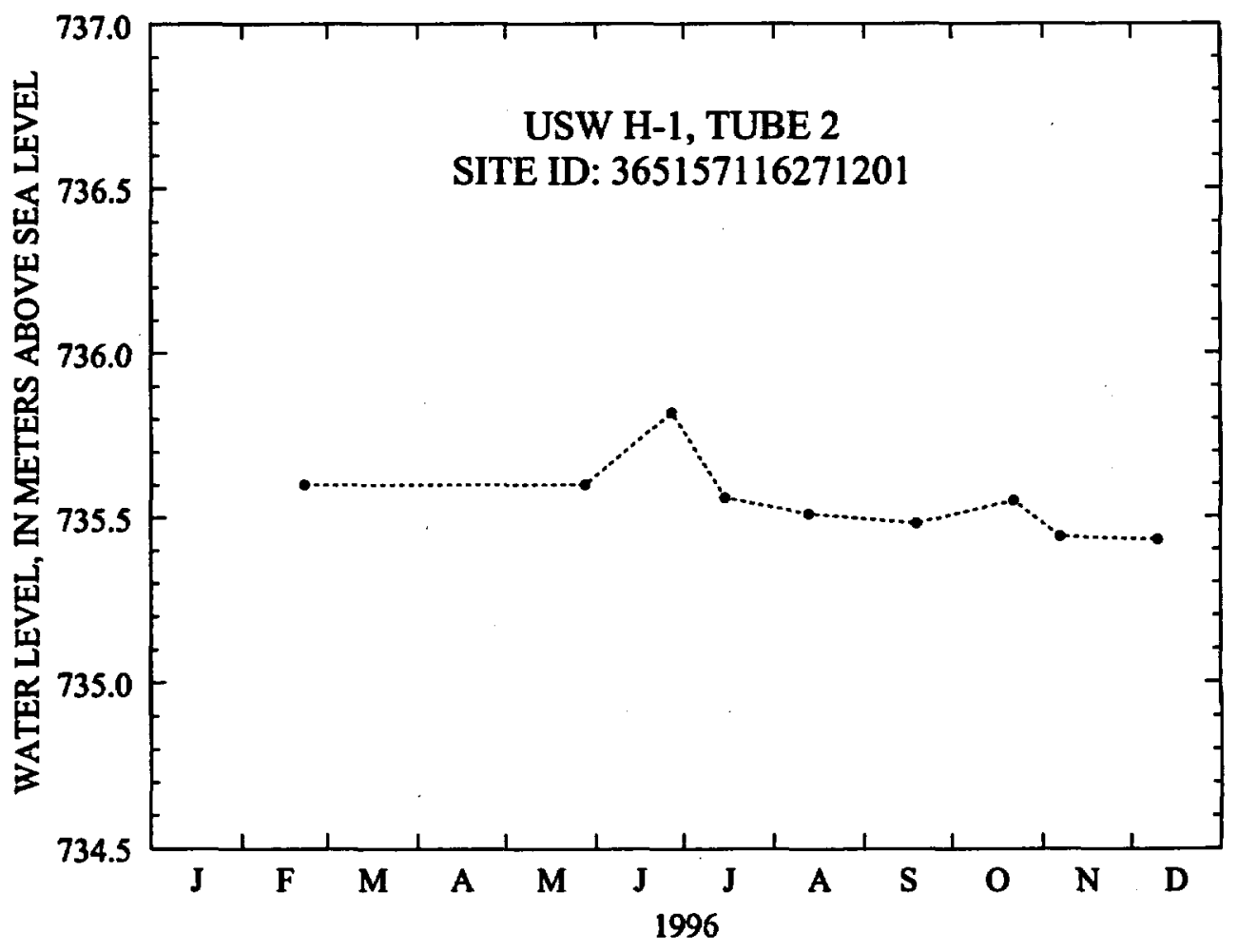

Figure 19. Water-level altitudes, 1996, for well USW H-1, tube 2.

\section{Tube 3:}

Well USW H-1, tube 3, was measured periodically during 1996, and water-level altitudes for well USW H-1, tube 3, ranged from 730.34 to $731.03 \mathrm{~m}$ above sea level in 1996 (fig. 20). The mean waterlevel altitude of the 1996 data was $730.61 \mathrm{~m}$ above sea level. This mean altitude was $0.03 \mathrm{~m}$ lower than the mean altitude of $730.64 \mathrm{~m}$ for 1995 (Graves and Goemaat, 1998) and $0.01 \mathrm{~m}$ higher than the mean altitude of $730.60 \mathrm{~m}$ for $1985-95$ (Graves and others, 1997). The measured water-level altitudes are listed in table 24 and shown in figure 20.

As mentioned for well USW WT-10, each tube monitored for USW H-1 had a sudden rise in water level during June 1996. In tube 3, the rise from May to June 1996 was about $0.27 \mathrm{~m}$. By July 1996, the water level in tube 3 declined back to a water level $0.15 \mathrm{~m}$ lower than the May water level. 
Table 24. Measured water-level altitudes, 1996, for well USW H-1, tube 3

\begin{tabular}{ccc}
\hline Date & $\begin{array}{c}\text { Measured water-level altitude } \\
\text { (meters above sea level) }\end{array}$ & Method of measuring water level \\
\hline $02-22-96$ & 730.76 & Chain \#3 \\
$05-28-96$ & 730.76 & Chain \#3 \\
$06-27-96$ & 731.03 & Chain \#3 \\
$07-15-96$ & 730.61 & Chain \#3 \\
$08-13-96$ & 730.56 & Chain \#3 \\
$09-19-96$ & 730.52 & Chain \#3 \\
$10-22-96$ & 730.34 & Chain \#3 \\
$11-07-96$ & 730.38 & Chain \#3 \\
$12-10-96$ & 730.54 & Chain \#3 \\
\hline
\end{tabular}

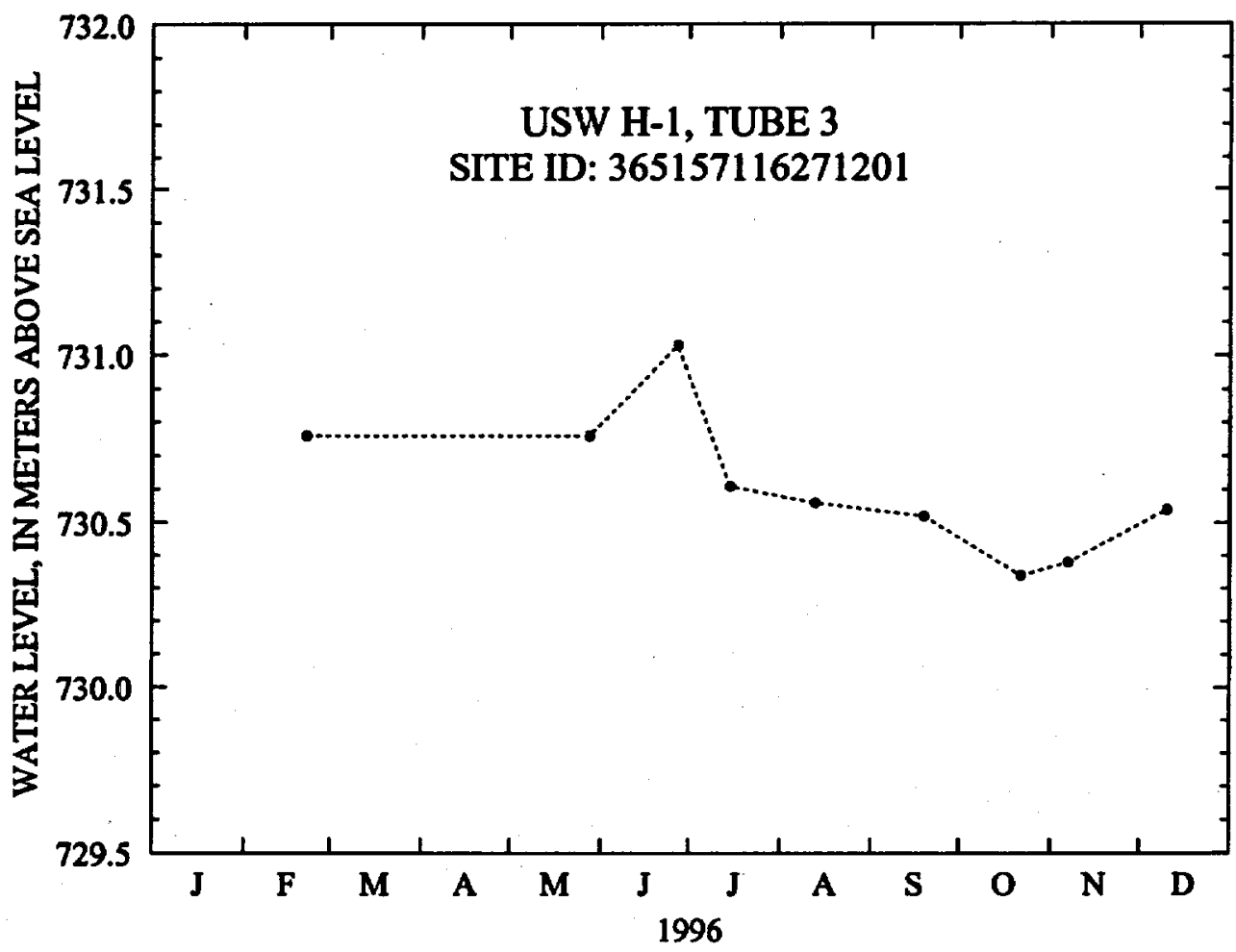

Flgure 20. Water-level altitudes, 1996, for well USW H-1, tube 3.

Tube 4:

Well USW H-1, tube 4, was measured periodically during 1996, and water-level altitudes ranged from 730.56 to $731.15 \mathrm{~m}$ above sea level in 1996 . The mean water-level altitude of the 1996 data was $730.78 \mathrm{~m}$ above sea level. This mean altitude was $0.13 \mathrm{~m}$ lower than the mean altitude of $730.91 \mathrm{~m}$ for 1995 (Graves and Goemaat, 1998), and $0.07 \mathrm{~m}$ lower than the mean altitude of $730.85 \mathrm{~m}$ for 1985-95 (Graves and others, 1997). The measured water-level altitudes are listed in table 25 and shown in figure 21. 
As mentioned for well USW WT-10, each tube monitored for USW H-1 had a sudden rise in water level during June 1996. In tube 4, the rise from May to June 1996 was about $0.25 \mathrm{~m}$. The water level in tube 3 declined back to a water level $0.18 \mathrm{~m}$ lower than the May water level during July 1996.

Table 25. Measured water-level altitudes, 1996, for well USW H-1, tube 4

\begin{tabular}{ccc}
\hline Date & $\begin{array}{c}\text { Measured water-level altitude } \\
\text { (meters above sea level) }\end{array}$ & Method of measuring water level \\
\hline $02-22-96$ & 730.93 & Chain \#3 \\
$05-28-96$ & 730.93 & Chain \#3 \\
$06-27-96$ & 731.15 & Chain \#3 \\
$07-15-96$ & 730.75 & Chain \#3 \\
$08-13-96$ & 730.70 & Chain \#3 \\
$09-19-96$ & 730.66 & Chain \#3 \\
$10-22-96$ & 730.60 & Chain \#3 \\
$11-07-96$ & 730.56 & Chain \#3 \\
$12-10-96$ & 730.72 & Chain \#3 \\
\hline
\end{tabular}

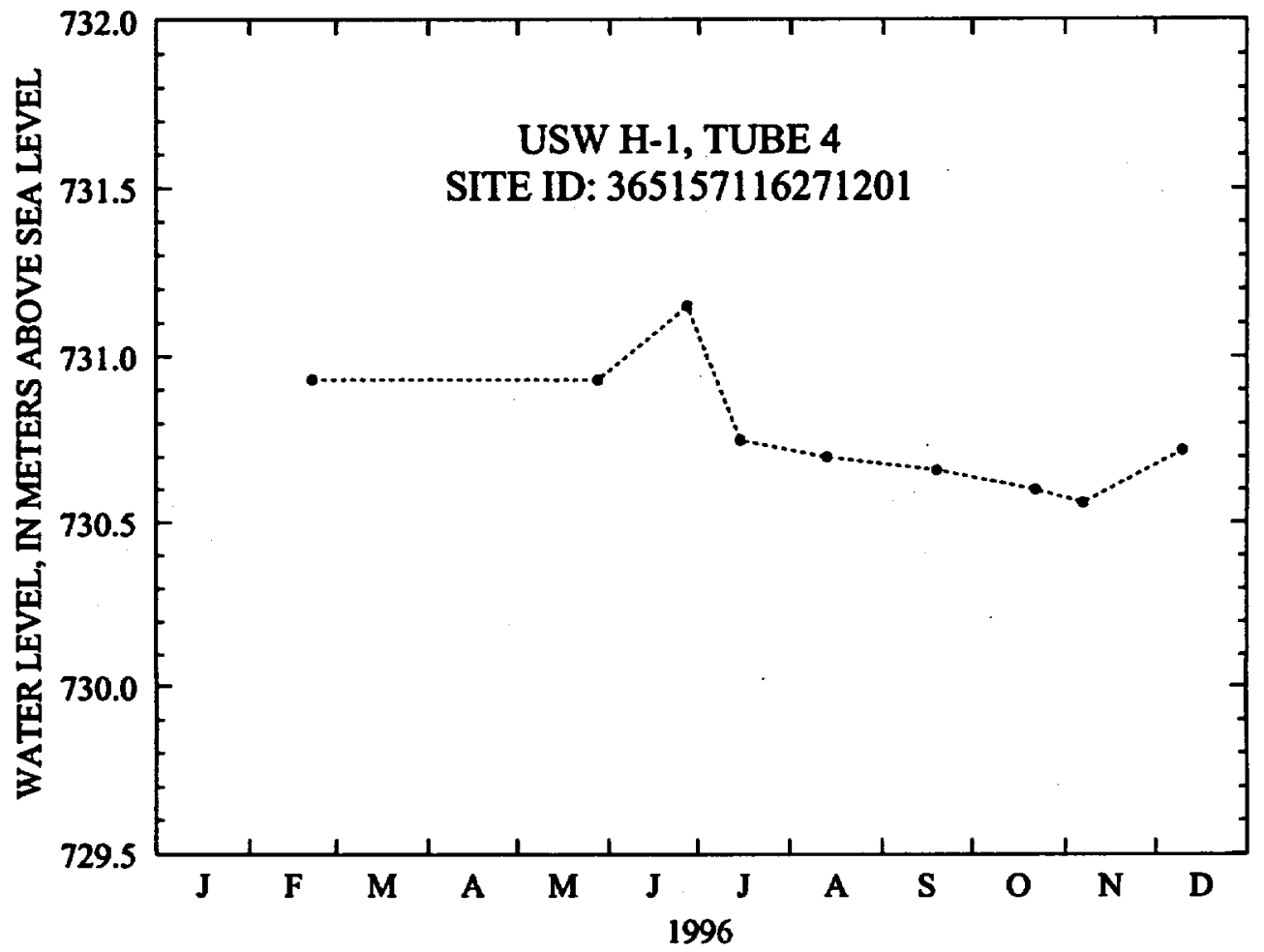

Figure 21. Water-level altitudes, 1996, for well USW H-1, tube 4. 


\section{Well USW H-3}

Information about the history of well USW H-3 and about previous data from the well was obtained from various sources. These sources are: Thordarson, Rush, Spengler, and Waddell (1984); Thordarson, Rush, and Waddell (1984); Robison (1984); J.H. Robison (U.S. Geological Survey, written commun., 1986); Robison and others (1988); and Fenix \& Scisson, Inc. (1987a, 1987c).

\section{Well specifications}

1. Location and identification:

Latitude and longitude: $36^{\circ} 49^{\prime} 42^{\prime \prime} \mathrm{N}$.; $116^{\circ} 28^{\prime} 00^{\prime \prime} \mathrm{W}$.

Nevada State Central Zone Coordinates (m): N 230,594; E 170,216.

U.S. Geological Survey Site ID: 364942116280001.

2. Drilling and casing information:

Well started: January 27, 1982.

Well completed: March 19, 1982.

Drilling method: Rotary, using rock bits and air-foam circulating medium.

Bit diameter below water level: $375 \mathrm{~mm}$ to $808 \mathrm{~m} ; 222 \mathrm{~m}$ from $808 \mathrm{~m}$ to $1,219 \mathrm{~m}$.

Casing extending below water level: $253 \mathrm{~mm}$ diameter to $792 \mathrm{~m}$, not perforated below the water level.

Total drilled depth: $1,219 \mathrm{~m}$.

3. Access to and description of depth intervals for measuring water levels:

\section{Upper interval:}

41-mm-inside-diameter open-ended tubing, extending from land surface to depth of about $762 \mathrm{~m}$; upper interval of well, from near water table to top of inflatable packer, is within bedded tuff and the Tram Tuff of the Crater Flat Group;

Lower interval:

62-mm-inside-diameter tubing that has an inflatable packer on bottom end extending from land surface to $1,061 \mathrm{~m}$; lower interval from below packer to bottom of well is within the Tram Member of the Crater Flat Tuff and the Lithic Ridge Tuff.

Note: Inflatable packer installed January 1983 at a depth of $1,190 \mathrm{~m}$; removed late November 1983 during period of additional hydraulic testing; reinstalled during May 1984 at depth of 1,114 m; removed and reinstalled during December 1990 at a depth of $1,061 \mathrm{~m}$.

4. Information for calculating water-level altitude:

Reference point: Top of metal tag on well casing; altitude $1483.47 \mathrm{~m}$ (surveyed by U.S. Geological Survey in 1984).

Measuring point: Top of access tubes, $0.174 \mathrm{~m}$, upper interval; $0.201 \mathrm{~m}$, lower interval. Each measuring point above reference point.

Depth correction for borehole deviation from vertical: $0.079 \mathrm{~m}$, upper interval, based on approximate depth to water of $752 \mathrm{~m}$ (1990 data); $0.058 \mathrm{~m}$, lower interval, based on approximate depth to water of $728 \mathrm{~m}$ (1990 data). 
Well USW H-3, upper interval, was measured periodically during 1996; however, water-level measurements for 1996 did not begin until July. During September 1995, Chain \#4 broke inside the monitoring tube of USW H-3, upper interval, blocking access to the water table. This blockage was not cleared until July 1996.

The 1996 water-level altitudes of well USW H-3, upper interval, ranged from 731.15 to $731.23 \mathrm{~m}$ above sea level. The mean water-level altitude of the 1996 data was $731.19 \mathrm{~m}$ above sea level. This mean altitude was $0.10 \mathrm{~m}$ lower than the mean altitude of $731.29 \mathrm{~m}$ for 1995 (Graves and Goemaat, 1998 ) and $0.33 \mathrm{~m}$ lower than the mean altitude of $731.52 \mathrm{~m}$ for 1985-95 (Graves and others, 1997). The measured water-level altitudes are listed in table 26 and shown in figure 22.

Table 26. Measured water-level altitudes, 1996, for well USW H-3, upper interval

\begin{tabular}{ccc}
\hline Date & $\begin{array}{c}\text { Measured water-level altitude } \\
\text { (meters above sea level) }\end{array}$ & Method of measuring water level \\
\hline $07-11-96$ & 731.19 & Chain \#3 \\
$07-23-96$ & 731.21 & 2,800 -foot reference steel tape \\
$08-19-96$ & 731.21 & 2,800 -foot reference steel tape \\
$09-23-96$ & 731.15 & Chain \#3 \\
$10-23-96$ & 731.18 & Chain \#3 \\
$11-14-96$ & 731.23 & Chain \#3 \\
$12-11-96$ & 731.18 & Chain \#3 \\
\hline
\end{tabular}

Well USW H-3, lower interval, was measured periodically during $1996^{6}$. Water-level altitudes ranged from 759.79 to $760.31 \mathrm{~m}$ above sea level in 1996 . The mean water-level altitude of the 1996 data was $760.07 \mathrm{~m}$ above sea level. This mean altitude was $0.84 \mathrm{~m}$ higher than the mean altitude of $759.23 \mathrm{~m}$ for 1995 (Graves and Goemaat, 1998) and $4.16 \mathrm{~m}$ higher than the mean altitude of $755.91 \mathrm{~m}$ for 1985 95 (Graves and others, 1997). The measured water-level altitudes are listed in table 27 and shown in figure 23. The reason for the significant difference in mean water levels is that the inflatable packer, which divides the well into two intervals, was moved to a different location on December 14, 1990. Since this move, the water level in the lower interval has been rising in the process of reaching equilibration to a new static water level.

${ }^{6}$ USW H-3, lower interval, was measured with greater frequency than USW H-3, upper interval, because of the blockage in the upper interval and because the lower interval was used to calibrate manual water-level monitoring equipment. 


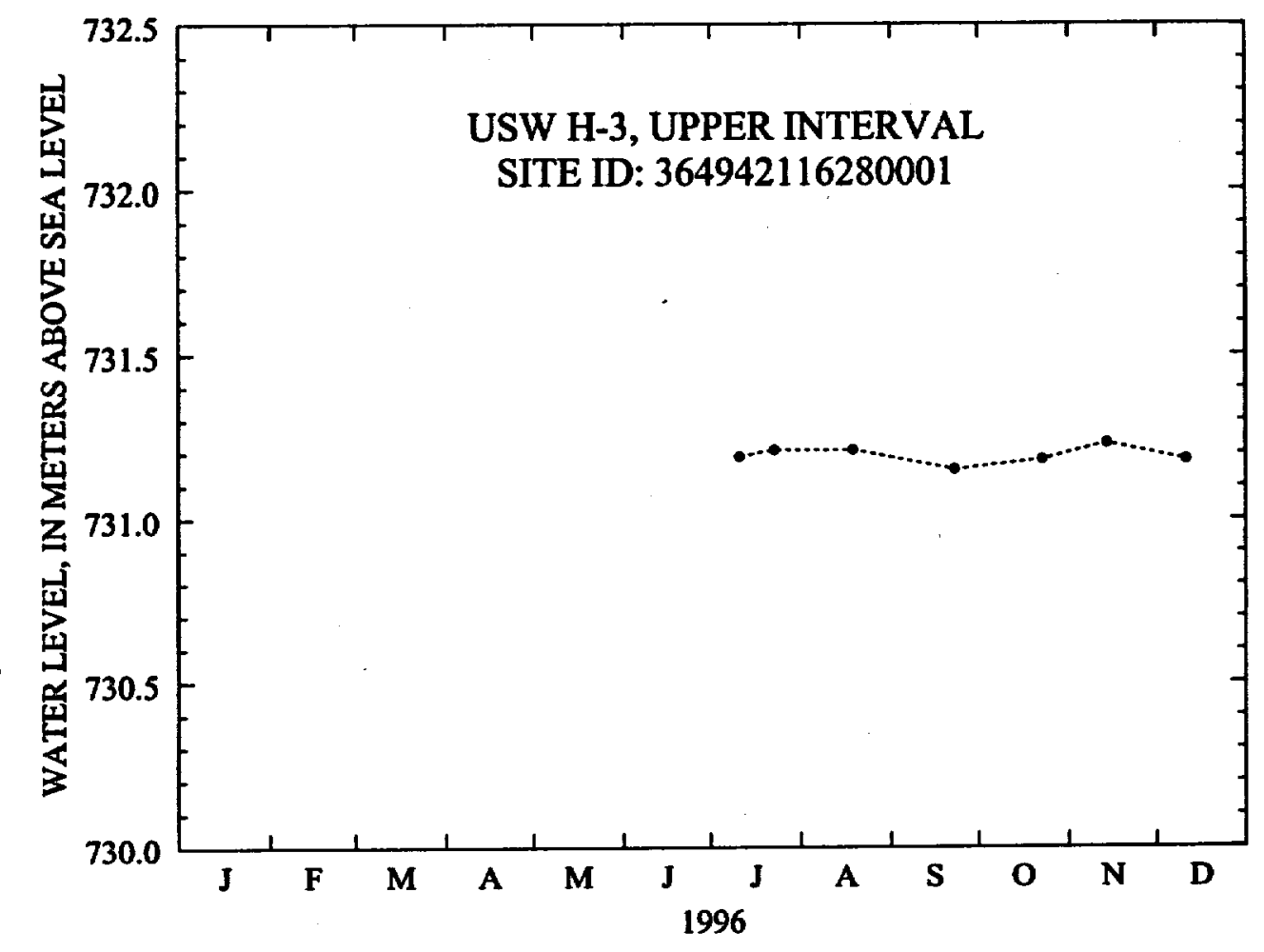

Figure 22. Water-level altitudes, 1996, for well USW H-3, upper interval.

Table 27. Measured water-level altitudes, 1996, for well USW H-3, lower interval

\begin{tabular}{ccc}
\hline Date & $\begin{array}{c}\text { Measured water-level altitude } \\
\text { (meters above sea leved) }\end{array}$ & Method of measuring water level \\
\hline $02-20-96$ & 759.79 & Chain \#3 \\
$05-23-96$ & 760.01 & Chain \#3 \\
$06-12-96$ & 760.04 & 2,800 -foot reference steel tape \\
$06-24-96$ & 760.05 & Chain \#3 \\
$07-17-96$ & 759.98 & Chain \#3 \\
$07-25-96$ & 759.86 & 2,800 -foot reference steel tape \\
$08-19-96$ & 760.16 & 2,800 -foot reference steel tape \\
$09-09-96$ & 760.15 & 2,800 -foot reference steel tape \\
$10-23-96$ & 760.18 & Chain \#3 \\
$11-14-96$ & 760.26 & Chain \#3 \\
$12-11-96$ & 760.31 & Chain \#3 \\
\hline
\end{tabular}




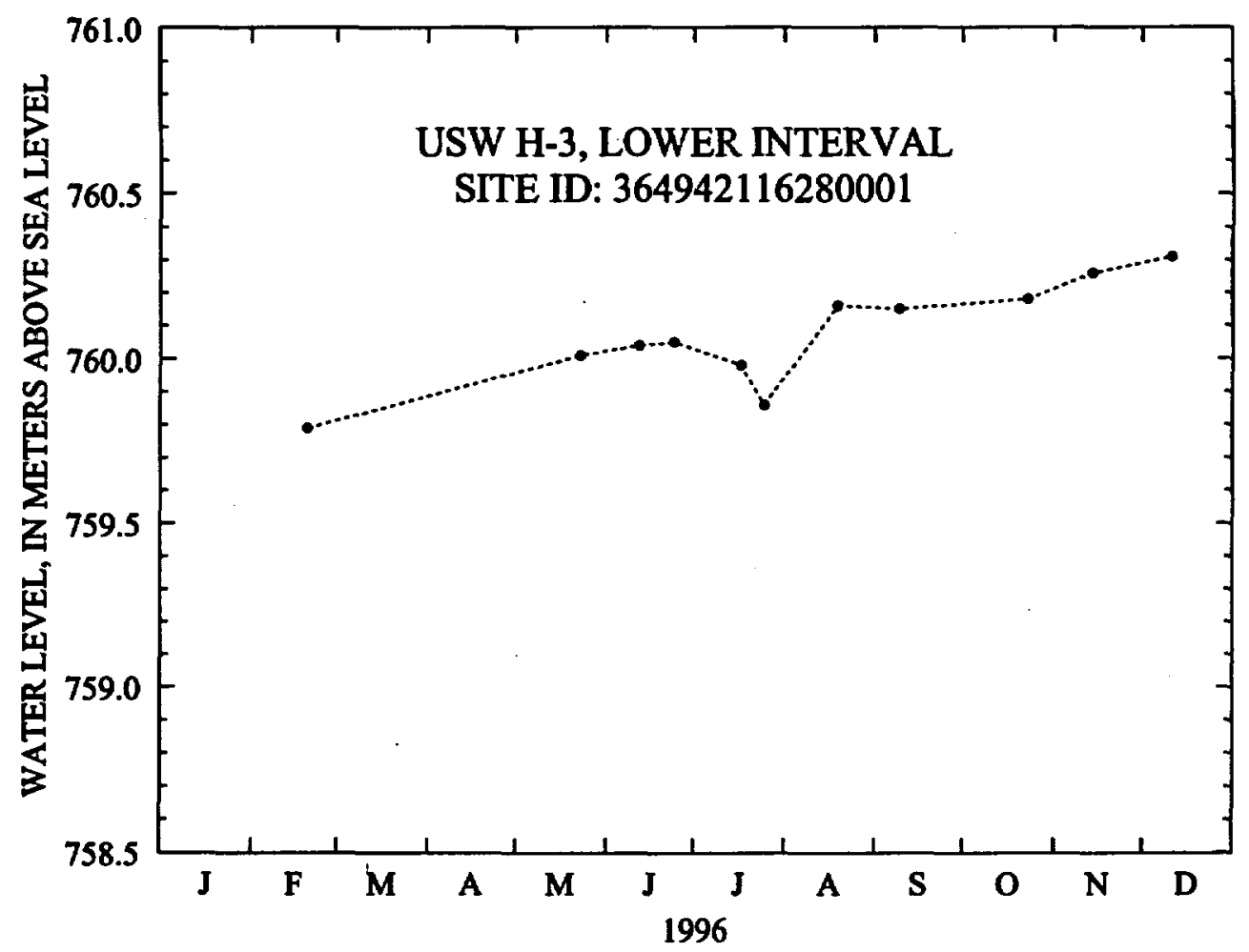

Figure 23. Water-level altitudes, 1996, for well USW H-3, lower interval.

The water level in well USW H-3 changed briefly during July 1996, with a decline of approximately $0.19 \mathrm{~m}$ from June to July. During August the water level rose about $0.3 \mathrm{~m}$ above the July water level. Because of the general rising trend in water levels in well USW H-3, lower interval, it was thought that the decline in water level during July was due to barometric or earth tide effects and the 0.3-m rise from July to August was a return to the normal rising trend in the well. However, if the decline during July was due to barometric or earth tide effects, then similar changes in other wells should have been observed, and they were not. During 1997, the packer in well USW H-3 failed, and water levels in the lower interval began to decline and continued to decline following the failure of the packer. With this new information from 1997, it is believed that the drop in water level during July 1996 was due to the packer briefly failing to allow a brief hydraulic connection between the upper and lower interval. The rise in water level from July to August was due to the packer resealing the well between the two intervals. 


\section{Well USW H-4}

Information about the history of well USW H-4 and about previous data from the well was obtained from various sources. These sources are: Whitfield and others (1984); Whitfield and others (1985);

Robison (1984); J.H. Robison (U.S. Geological Survey, written commun., 1986); Robison and others (1988);

Erickson and Waddell (1985); and Fenix \& Scisson, Inc. (1987a, 1987c).

Well specifications

\section{Location and identification:}

Latitude and longitude: $36^{\circ} 50^{\prime} 32^{\prime \prime} \mathrm{N} . ; 116^{\circ} 26^{\prime} 54^{\prime \prime} \mathrm{W}$.

Nevada State Central Zone Coordinates (m): N 232,149; E 171,880.

U.S. Geological Survey Site ID: 365032116265401.

2. Drilling and casing information:

Well started: March 22, 1982.

Well completed: June 7, 1982.

Drilling method: Rotary, using rock bits and air-foam circulating medium; cores obtained from selected intervals.

Bit diameter below water level: $375 \mathrm{~mm}$ to $564 \mathrm{~m} ; 222 \mathrm{~mm}$ from $564 \mathrm{~m}$ to $1,219 \mathrm{~m}$.

Casing extending below water level: $253 \mathrm{~mm}$ diameter to $561 \mathrm{~m}$, perforated below the water level.

Total drilled depth: $1,219 \mathrm{~m}$.

3. Access to and description of depth interval for measuring water levels:

Upper interval:

48-mm-inside-diameter open-ended tubing, extending from land surface to depth of $525 \mathrm{~m}$; upper interval of well near water table to top of inflatable packer is within the Prow Pass, Bullfrog, and Tram Tuffs of the Crater Flat Group, bedded tuff, and upper Lithic Ridge Tuff;

Lower interval:

62-mm-inside-diameter tubing with inflatable packer on bottom end, extending from land surface to $1,188 \mathrm{~m}$; lower interval of well is within the Lithic Ridge Tuff.

4. Information for calculating water-level altitude:

Reference point: Top of metal tag on well casing; altitude $1,248.74 \mathrm{~m}$ (surveyed by U.S. Geological Survey in 1984).

Measuring point: Top of access tubes, $0.597 \mathrm{~m}$, upper interval; $0.308 \mathrm{~m}$, lower interval. Both measuring points above reference point.

Depth correction for borehole deviation from vertical: $0.064 \mathrm{~m}$, based on approximate depth to water of $518 \mathrm{~m}$ (1990 data). 
Well USW H-4, upper interval, was measured periodically ${ }^{7}$ during 1996 , and water-level altitudes ranged from 730.11 to $730.41 \mathrm{~m}$ above sea level in 1996. The mean water-level altitude of the 1996 data was $730.28 \mathrm{~m}$ above sea level. This mean altitude was $0.09 \mathrm{~m}$ lower than the mean altitude of $730.37 \mathrm{~m}$ for 1995 (Graves and Goemaat, 1998) and $0.12 \mathrm{~m}$ lower than the mean altitude of $730.40 \mathrm{~m}$ for $1985-95$ (Graves and others, 1997). The measured water-level altitudes are listed in table 28 and shown in figure 24. The lower water levels in well USW H-4, upper interval, are believed to be due to the pumpage at the C-hole complex that began on May 8, 1996. Through December 31, 1996, an estimated 196 million liters was pumped from well UE-25 $\mathrm{c \# 3}$.

Table 28. Measured water-level altitudes, 1996, for well USW H-4, upper interval

\begin{tabular}{ccc}
\hline Date & $\begin{array}{c}\text { Measured water-level allitude } \\
\text { (meters above sea level) }\end{array}$ & Method of measuring water level \\
\hline $02-21-96$ & 730.41 & Chain \#3 \\
$04-30-96$ & 730.32 & Chain \#3 \\
$05-07-96$ & 730.39 & Chain \#3 \\
$08-28-96$ & 730.16 & Chain \#3 \\
$12-04-96$ & 730.11 & Chain \#3 \\
\hline
\end{tabular}

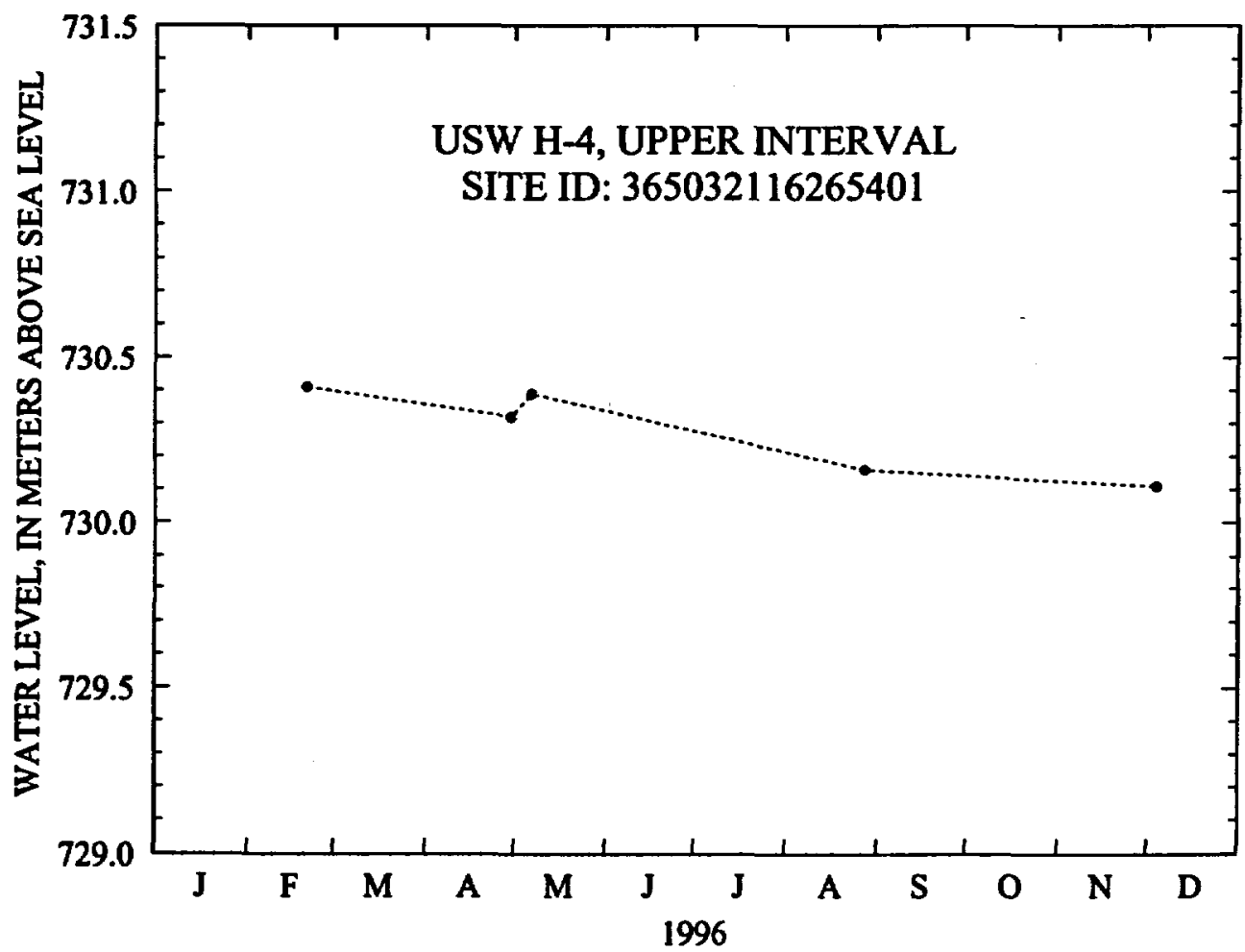

Figure 24. Water-level altitudes, 1996, for well USW H-4, upper interval.

\footnotetext{
${ }^{7}$ Continuous data collection of well USW H-4, upper interval, was initiated on May 7, 1996, in support of scheduled hydraulic testing at the C-hole complex (fig. 1). Collection of the continuous data continued through December 31, 1996.
} 
Well USW H-4, lower interval, was measured periodically during 1996, and water-level altitudes ranged from 730.27 to $730.49 \mathrm{~m}$ above sea level in 1996. The mean water-level altitude of the 1996 data was $730.39 \mathrm{~m}$ above sea level. This mean altitude was $0.11 \mathrm{~m}$ lower than the mean altitude of $730.50 \mathrm{~m}$ for 1995 (Graves and Goemaat, 1998) and $0.15 \mathrm{~m}$ lower than the mean altitude of $730.51 \mathrm{~m}$ for $1985-95$ (Graves and others, 1997). The measured water-level altitudes are listed in table 29 and shown in figure 25 . The lower water levels in well USW $\mathrm{H}-4$, lower interval, are believed to be due to the pumpage at the C-hole complex that began on May 8, 1996. Through December 31, 1996, an estimated 196 million liters was pumped from well UE-25 c\#3.

Table 29. Measured water-level altitudes, 1996, for well USW H-4, lower interval

\begin{tabular}{ccc}
\hline Date & $\begin{array}{c}\text { Measured water-level allitude } \\
\text { (meters above sea level) }\end{array}$ & Method of measurlng water level \\
\hline $02-21-96$ & 730.49 & Chain \#3 \\
$04-30-96$ & 730.40 & Chain \#3 \\
$05-07-96$ & 730.49 & Chain \#3 \\
$08-28-96$ & 730.28 & Chain \#3 \\
$12-04-96$ & 730.27 & Chain \#3 \\
\hline
\end{tabular}

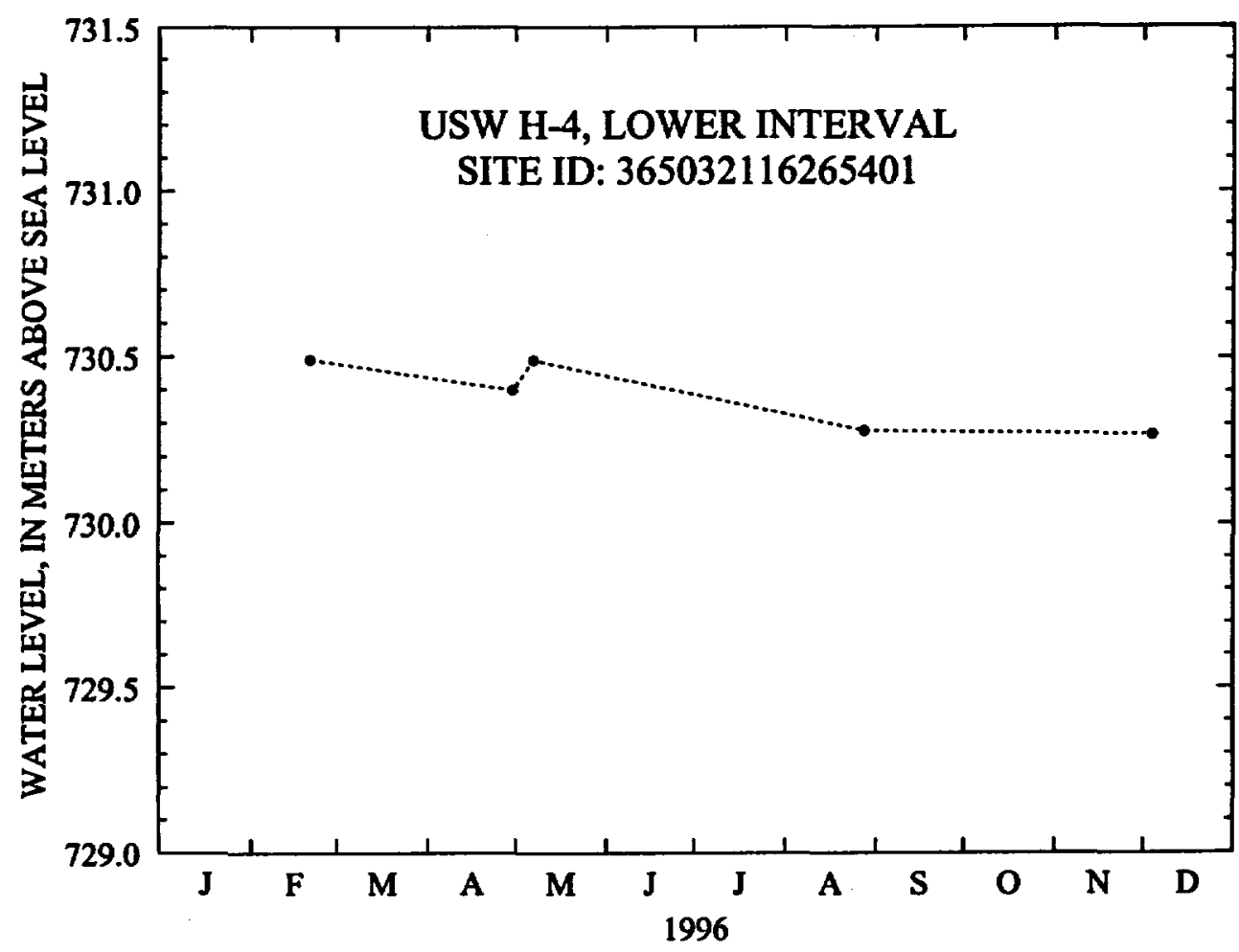

Figure 25. Water-level altitudes, 1996, for well USW H-4, lower interval. 


\section{Well USW H-5}

Information about the history of well USW H-5 and about previous data from the well was obtained from various sources. These sources are: Bentley and others (1983); Robison (1984); J.H. Robison (U.S. Geological Survey, written commun., 1986); Robison and others (1988); Fenix \& Scisson, Inc. (1987a, 1987c); Carr (1988, p. 37); and Sawyer and others (1994, p. 1305).

Well specifications

1. Location and identification:

Latitude and longitude: $36^{\circ} 51^{\prime 2} 22^{\prime \prime N}$.; $116^{\circ} 27^{\prime} 55^{\prime \prime} \mathrm{W}$.

Nevada State Central Zone Coordinates (m): N 233,670; E 170,355.

U.S. Geological Survey Site ID: 365122116275502.

2. Drilling and casing information:

Well started: May 19, 1982.

Well completed: August 1, 1982.

Drilling method: Rotary, using rock bits and air-foam circulating medium; cores obtained from selected intervals.

Bit diameter below water level: $375 \mathrm{~mm}$ to $792 \mathrm{~m} ; 222 \mathrm{~mm}$ from $792 \mathrm{~m}$ to $1,219 \mathrm{~m}$.

Casing extending below water level: $255-\mathrm{mm}$ diameter to $788 \mathrm{~m}$, perforated below the water level.

Total drilled depth: $1,219 \mathrm{~m}$.

3. Access to and description of depth interval for measuring water levels:

Upper interval:

48-mm-inside-diameter open-ended tubing, extending from land surface to a depth of $709 \mathrm{~m}$; upper saturated interval of the borehole is within the Bullfrog Tuff of the Crater Flat Group.

Lower interval:

62-mm-inside-diameter tubing that has a 3.6-m-long inflatable packer on bottom end, extending from land surface to $846 \mathrm{~m}$; lower interval is within the Bullfrog and Tram Tuffs of the Crater Flat Group and an unnamed tuff between the Bullfrog and Tram Tuffs.

Note: The packer was reset at its present depth $(846 \mathrm{~m})$ on $3 / 25 / 93$, from its previous depth of 1,091 m (G.M. O'Brien, U.S. Geological Survey, written commun., 1993).

4. Information for calculating water-level altitude:

Reference point: Top of metal tag on well casing; altitude $1,478.94 \mathrm{~m}$ (surveyed by U.S. Geological Survey in 1984).

Measuring point: Top of access tubes, $0.329 \mathrm{~m}$, upper interval; $0.235 \mathrm{~m}$, lower interval. Both measuring points above the reference point.

Depth correction for borehole deviation from vertical: $0.079 \mathrm{~m}$, based on approximate depth to water of $703 \mathrm{~m}$ (1990 data). 
Well USW H-5, upper interval, was measured hourly and periodically during 1996 . Hourly measurements were made until August 27, 1996, the day hourly data collection was discontinued. During the period of hourly measurements, two calibrations of one transducer were performed. In addition, a calibration was completed on December 18, 1995. This calibration was used to calculate water-level altitudes at the beginning of 1996. Results of the transducer calibrations are as follows:

\begin{tabular}{cccccc}
\hline $\begin{array}{c}\text { Transducer serial } \\
\text { number }\end{array}$ & $\begin{array}{c}\text { Calibration } \\
\text { date }\end{array}$ & $\begin{array}{c}\text { Slope } \\
\text { (meter per } \\
\text { millivoli) }\end{array}$ & $\begin{array}{c}\text { Coeficlent of } \\
\text { determination }\end{array}$ & $\begin{array}{c}\text { Water-level } \\
\text { altitude } \\
\text { (meters) }\end{array}$ & $\begin{array}{c}\text { Method of measuring } \\
\text { water level }\end{array}$ \\
\hline 570799 & $12-18-95$ & 0.089 & 1.000 & 775.40 & Tag with transducer \\
570799 & $06-04-96$ & .088 & 1.000 & 775.44 & Chain \#3 \\
570799 & $08-27-96$ & .088 & 1.000 & 775.47 & Chain \#3 \\
\hline
\end{tabular}

No data were collected for well USW H-5, upper interval, from January 1, 1996, through March 28, 1996. Data were lost because of wiring problems due to removal and incorrect installation of a barometer at the well. Partial data were collected on April 27 and 28, June 4, 5, and 6, and August 8, 1996. The partial data collected on these dates were due to the removal of the transducers from the upper and lower intervals (June 4 and 5,1996 ) and to random spikes in the data. All other transducer data collected for 1996 were considered valid.

Following the removal of the transducer, well USW H-5, upper interval, was measured periodically during the remainder of 1996. Daily mean water-level altitudes of the hourly data for well USW H-5, upper interval, ranged from 775.37 to $775.54 \mathrm{~m}$ above sea level in 1996 (fig. 26). The water-level altitudes of the manual waterlevel measurements made are within this range. Monthly mean water-level altitudes for 1996 are listed in table 30. The measured water-level altitudes are listed in table 31. The mean water-level altitude of the 1996 data was $775.46 \mathrm{~m}$ above sea level. This mean altitude was $0.06 \mathrm{~m}$ higher than the mean altitude of $775.40 \mathrm{~m}$ for 1995 (Graves and Goemaat, 1998) and the same as the mean altitude of $775.46 \mathrm{~m}$ for 1985-95 (Graves and others, 1997).

Table 30. Monthly mean water-level altitudes, 1996, from daily mean water levels for well USW H-5, upper interval.

[--, data not available; NA, not applicable, well not instrumented during this month]

\begin{tabular}{lcc}
\hline Month & $\begin{array}{c}\text { Monthly mean } \\
\text { water-level altttude } \\
\text { (moters above sea level) }\end{array}$ & $\begin{array}{c}\text { Number of missing dalty } \\
\text { means }\end{array}$ \\
\hline January & - & 31 \\
February & 775.45 & 29 \\
March & 775.44 & 28 \\
April & 775.49 & 2 \\
May & 775.48 & 0 \\
June & 775.45 & 3 \\
July & 775.45 & 0 \\
August & NA & 1 \\
September & NA & NA \\
October & NA & NA \\
November & NA & NA \\
December & & NA \\
\hline
\end{tabular}




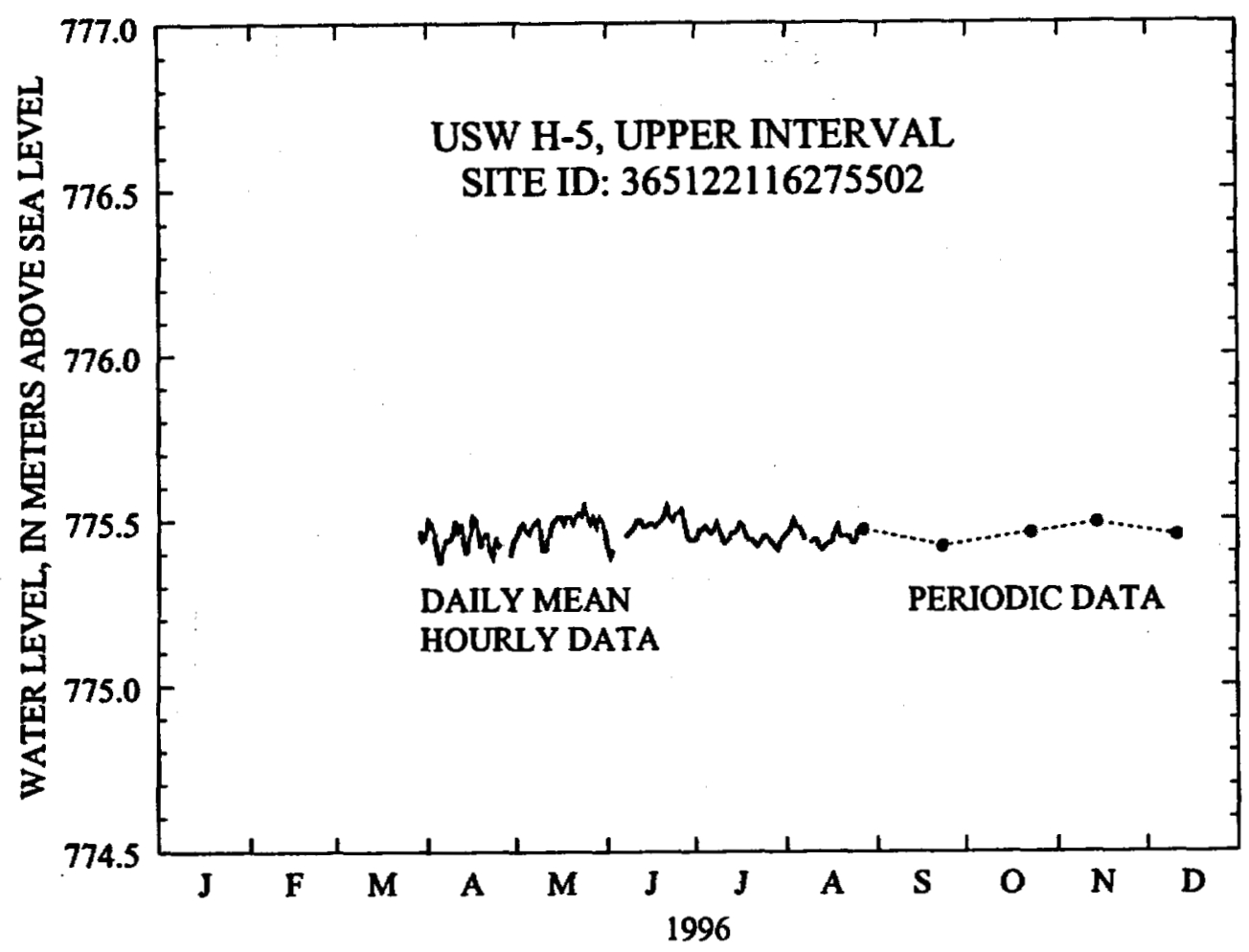

Figure 26. Water-level altitudes, 1996, for well USW H-5, upper interval.

Table 31. Measured water-level altitudes, 1996, for well USW H-5, upper interval

\begin{tabular}{ccc}
\hline Date & $\begin{array}{c}\text { Measured water-level altitude } \\
\text { (meters above sea level) }\end{array}$ & Method of measuring water lovel \\
\hline $06-04-96$ & 775.44 & Chain \#3 \\
$08-27-96$ & 775.47 & Chain \#3 \\
$09-23-96$ & 775.42 & Chain \#3 \\
$10-23-96$ & 775.46 & Chain \#3 \\
$11-14-96$ & 775.49 & Chain \#3 \\
$12-11-96$ & 775.45 & Chain \#3 \\
\hline
\end{tabular}

Well USW H-5, lower interval, was measured hourly and periodically during 1996. Hourly measurements were made until August 8, 1996, the day hourly data collection was discontinued. During the period of hourly measurements, a calibration of one transducer was performed. In addition, a calibration was completed on December 19, 1995. This calibration was used to calculate water-level altitudes at the beginning of 1996. Results of the transducer calibrations are as follows:

\begin{tabular}{cccccc}
\hline $\begin{array}{c}\text { Transducer serlal } \\
\text { number }\end{array}$ & $\begin{array}{c}\text { Calibration } \\
\text { date }\end{array}$ & $\begin{array}{c}\text { Slope } \\
\text { (meter per } \\
\text { millivolt) }\end{array}$ & $\begin{array}{c}\text { Coefficlent of } \\
\text { determination }\end{array}$ & $\begin{array}{c}\text { Water-level } \\
\text { altitude } \\
\text { (meters) }\end{array}$ & $\begin{array}{c}\text { Method of measuring } \\
\text { water level }\end{array}$ \\
\hline 631046 & $12-19-95$ & 0.376 & 0.991 & 775.76 & Tag with transducer \\
631046 & $06-05-96$ & .356 & 1.000 & 775.71 & Chain \#3 \\
631046 & $08-08-96$ & $\begin{array}{c}\text { Transducer } \\
\text { failed } \\
\text { calibration }\end{array}$ & $\begin{array}{c}\text { Transducer } \\
\text { failed } \\
\text { calibration }\end{array}$ & 775.68 & Chain \#3 \\
& & & & & \\
\hline
\end{tabular}


No data were collected from well USW H-5, lower interval, from January 1, through March 27, 1996. The data were lost because of the removal and incorrect installation of a barometer at the well. Data were not converted from March 27 through April 29, 1996, because of unexplainable irregularities in the data. Partial data were collected on June 4, 5, and 6, 1996. The partial data collected on June 4 and 5 were due to the removal of the transducers from the upper and lower intervals on these dates. The partial data collected on June 6 were due to random spikes in the data. Transducer number 631046 failed on August 3, 1996, and an attempt at a closing calibration on August 8, 1996, was unsuccessful. The water-level data collected through August 3, 1996, were reviewed and compared to manual water-level measurements made on June 5 and August 8, 1996, and to water-level fluctuations in the upper interval of well USW H-5. Following the review of data, it was determined that the data collected from the previous calibration (June 5, 1996) to August 3, 1996, were good.

Following the removal of the transducer, well USW H-5, lower interval, was measured periodically during the remainder of 1996. Daily mean water-level altitudes of the hourly data for well USW H-5, lower interval, ranged from 775.45 to $775.71 \mathrm{~m}$ above sea level in 1996 (fig. 27). The upper range of the water-level altitude of the manual water-level measurements was $775.79 \mathrm{~m}$. Monthly mean water-level altitudes for 1996 are listed in table 32. The measured water-level altitudes are listed in table 33. The mean water-level altitude of the 1996 data was $775.65 \mathrm{~m}$. This mean altitude was $0.13 \mathrm{~m}$ lower than the mean altitude of $775.78 \mathrm{~m}$ for 1995 (Graves and Goemaat, 1998) and $0.03 \mathrm{~m}$ higher than the mean altitude of $775.62 \mathrm{~m}$ for $1985-95$ (Graves and others, 1997).

Table 32. Monthly mean water-level altitudes, 1996, from daily mean water levels for well USW H-5, lower interval.

[--, data not available; NA, not applicable, well not instrumented during this month]

\begin{tabular}{lcc}
\hline Month & $\begin{array}{c}\text { Monthly mean } \\
\text { water-level altitude } \\
\text { (meters above sea level) }\end{array}$ & $\begin{array}{c}\text { Number of missing daily } \\
\text { means }\end{array}$ \\
\hline January & - & 31 \\
February & - & 29 \\
March & - & 31 \\
April & 775.49 & 29 \\
May & 775.61 & 0 \\
June & 775.65 & 3 \\
July & 775.55 & 0 \\
August & 775.61 & 6 \\
September & NA & NA \\
October & NA & NA \\
November & NA & NA \\
December & NA & NA \\
\hline
\end{tabular}




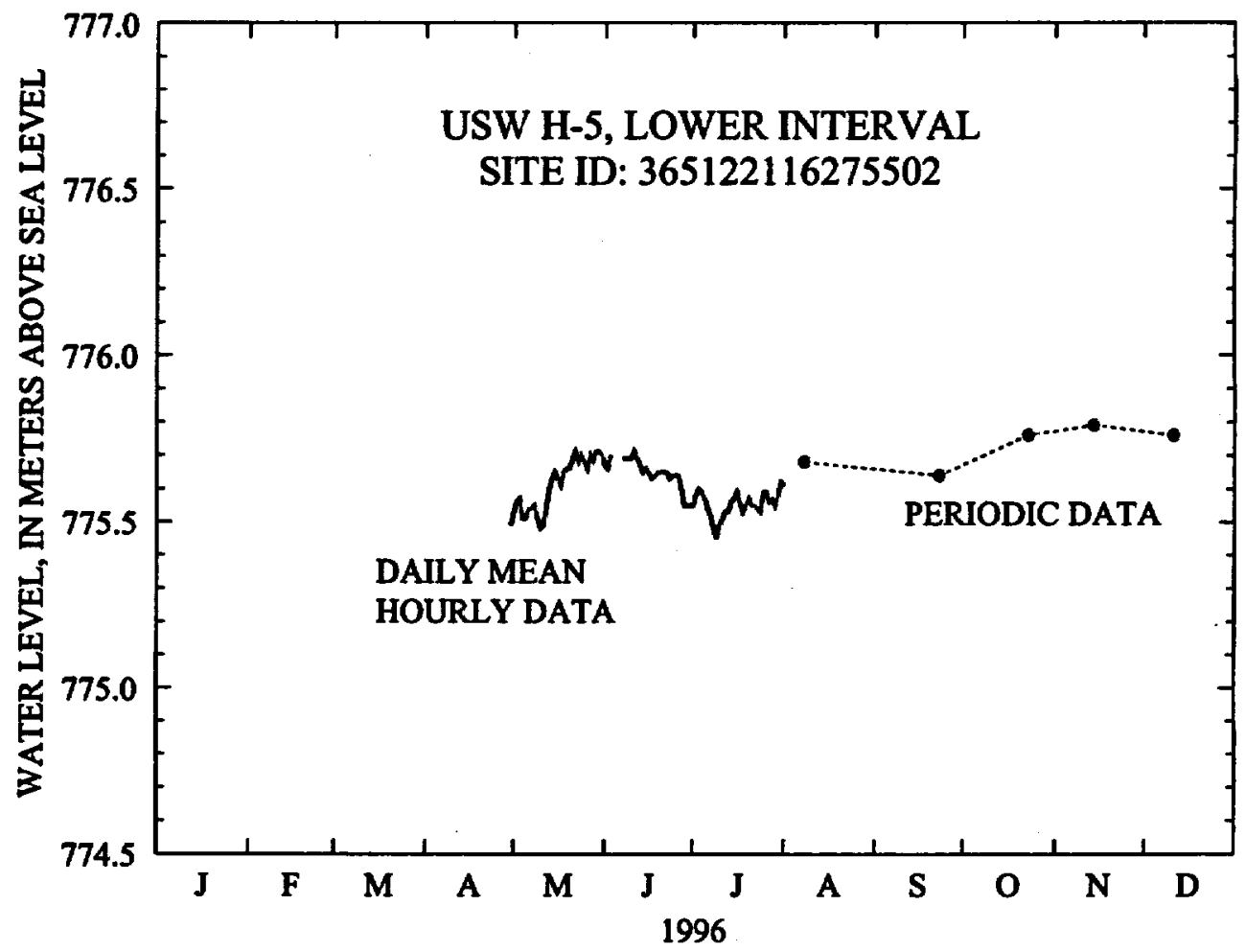

Figure 27. Water-level altitudes, 1996, for well USW H-5, lower interval.

Table 33. Measured water-level altitudes, 1996, for well USW H-5, lower interval

\begin{tabular}{ccc}
\hline Date & $\begin{array}{c}\text { Measured water-level altitude } \\
\text { (meters above sea level) }\end{array}$ & Method of measuring water level \\
\hline $06-05-96$ & 775.71 & Chain \#3 \\
$08-08-96$ & 775.68 & Chain \#3 \\
$09-23-96$ & 775.64 & Chain \#3 \\
$10-23-96$ & 775.76 & Chain \#3 \\
$11-14-96$ & 775.79 & Chain \#3 \\
$12-11-96$ & 775.76 & Chain \#3 \\
\hline
\end{tabular}




\section{Well USW H-6}

Information about the history of well USW H-6 and about previous data from the well was obtained from various sources. These sources are: Craig and others (1983); J.H. Robison (1984); Robison (U.S. Geological Survey, written commun., 1986); Robison and others (1988); and Fenix \& Scisson, Inc. (1987a, 1987c).

Well specifications

1. Location and identification:

Latitude and longitude: $36^{\circ} 50^{\prime} 49^{\prime \prime} \mathrm{N} . ; 116^{\circ} 28^{\prime} 55^{\prime \prime} \mathrm{W}$.

Nevada State Central Zone Coordinates (m): N 232,654; E 168,882.

U.S. Geological Survey Site ID: 365049116285501.

2. Drilling and casing information:

Well started: August 7, 1982.

Well completed: October 28, 1982.

Drilling method: Rotary, using rock bits and air-foam circulating medium; cores obtained from selected intervals.

Bit diameter below water level: $375 \mathrm{~mm}$ to $583 \mathrm{~m} ; 222 \mathrm{~mm}$ from $583 \mathrm{~m}$ to $1,216 \mathrm{~m}$; $156 \mathrm{~mm}$ from $1,216 \mathrm{~m}$ to $1,220 \mathrm{~m}$.

Casing extending below water level: $250-\mathrm{mm}$ diameter to $581 \mathrm{~m}$, perforated below the water level.

Total drilled depth: $1,220 \mathrm{~m}$.

3. Access to and description of depth interval for measuring water levels:

\section{Upper interval:}

48-mm-inside-diameter open-ended tubing, extending from land surface to $533 \mathrm{~m}$; saturated upper interval is within the Prow Pass, Bullfrog, and Tram Tuffs of the Crater Flat Group, and bedded tuff;

\section{Lower interval:}

62-mm-inside-diameter tubing with inflatable packer on bottom end, extending from land surface to $752 \mathrm{~m}$; lower interval is within the Tram Tuff of the Crater Flat Group, bedded tuff, an unnamed lava between the Tram Tuff and Lithic Ridge Tuff (Carr, 1988, p. 37; Sawyer and others, 1994, p. 1305), and the Lithic Ridge Tuff.

4. Information for calculating water-level altitude:

Reference point: Top of metal tag on well casing; altitude $1,302.06 \mathrm{~m}$ (surveyed by U.S. Geological Survey in 1984).

Measuring point: Top of access tubes, $0.207 \mathrm{~m}$ above reference point, upper interval; $0.235 \mathrm{~m}$ above reference point, lower interval.

Depth correction for borehole deviation from vertical: $0.052 \mathrm{~m}$, based on approximate depth to water of $526 \mathrm{~m}$ (1990 data). 
Well USW H-6, upper interval, was measured periodically during 1996 and water-level altitudes ranged from 776.07 to $776.16 \mathrm{~m}$ above sea level in 1996. The mean water-level altitude of the 1996 data was $776.12 \mathrm{~m}$ above sea level. This mean altitude was $0.01 \mathrm{~m}$ lower than the mean altitude of $776.13 \mathrm{~m}$ for 1995 (Graves and Goemaat, 1998) and $0.10 \mathrm{~m}$ higher than the mean altitude of $776.02 \mathrm{~m}$ for 1985-95 (Graves and others, 1997). The measured water-level altitudes are listed in table 34 and shown in figure 28.

Table 34. Measured water-level altitudes, 1996, for well USW H-6, upper interval

\begin{tabular}{ccc}
\hline Date & $\begin{array}{c}\text { Measured water-level altfude } \\
\text { (meters above sea level) }\end{array}$ & Method of measuring water level \\
\hline $02-26-96$ & 776.16 & Chain \#3 \\
$05-22-96$ & 776.13 & Chain \#3 \\
$06-19-96$ & 776.14 & Chain \#3 \\
$07-16-96$ & 776.13 & Chain \#3 \\
$08-12-96$ & 776.13 & Chain \#3 \\
$09-17-96$ & 776.08 & Chain \#3 \\
$10-16-96$ & 776.12 & Chain \#3 \\
$11-13-96$ & 776.09 & Chain \#3 \\
$12-12-96$ & 776.07 & Chain \#3 \\
\hline
\end{tabular}

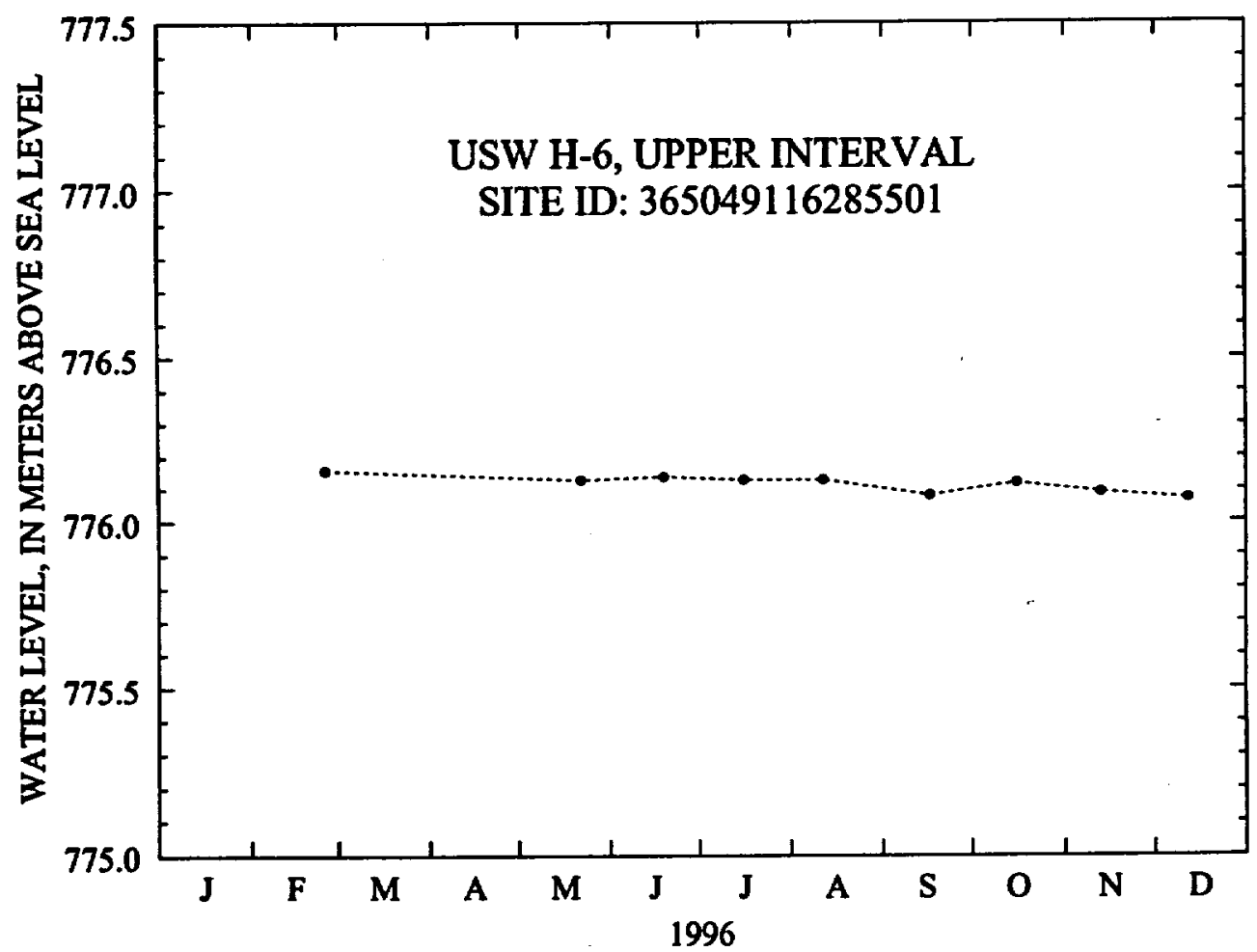

Figure 28. Water-level altitudes, 1996, for well USW H-6, upper interval. 
Well USW H-6, lower interval, was measured periodically during 1996, and water-level altitudes ranged from 775.96 to $776.10 \mathrm{~m}$ above sea level in 1996. The mean water-level altitude of the 1996 data was $776.00 \mathrm{~m}$ above sea level. This mean altitude was $0.01 \mathrm{~m}$ lower than the mean altitude of $776.01 \mathrm{~m}$ for 1995 (Graves and Goemaat, 1998) and $0.06 \mathrm{~m}$ higher than the mean altitude of $775.94 \mathrm{~m}$ for $1985-95$ (Graves and others, 1997). The measured water-level altitudes are listed in table 35 and shown in figure 29.

As mentioned for wells USW WT-10 and USW H-1, tubes 1, 2, 3, and 4, the lower interval of USW H-6 had a sudden rise in water level during June 1996. In the lower interval of well USW H-6, the rise from May to June 1996 was about $0.10 \mathrm{~m}$. By July 1996, the water level in the lower interval declined back to a water level slightly higher than the May water level.

Table 35. Measured water-level altitudes, 1996, for well USW H-6, lower interval

\begin{tabular}{ccc}
\hline Date & $\begin{array}{c}\text { Measured water-level altitude } \\
\text { (meters above sea level) }\end{array}$ & Method of measuring water level \\
\hline $02-26-96$ & 776.04 & Chain \#3 \\
$05-22-96$ & 776.00 & Chain \#3 \\
$06-19-96$ & 776.10 & Chain \#3 \\
$07-16-96$ & 776.01 & Chain \#3 \\
$08-12-96$ & 776.02 & Chain \#3 \\
$09-17-96$ & 775.96 & Chain \#3 \\
$10-16-96$ & 775.99 & Chain \#3 \\
$11-13-96$ & 775.96 & Chain \#3 \\
$12-12-96$ & 775.96 & Chain \#3 \\
\hline
\end{tabular}

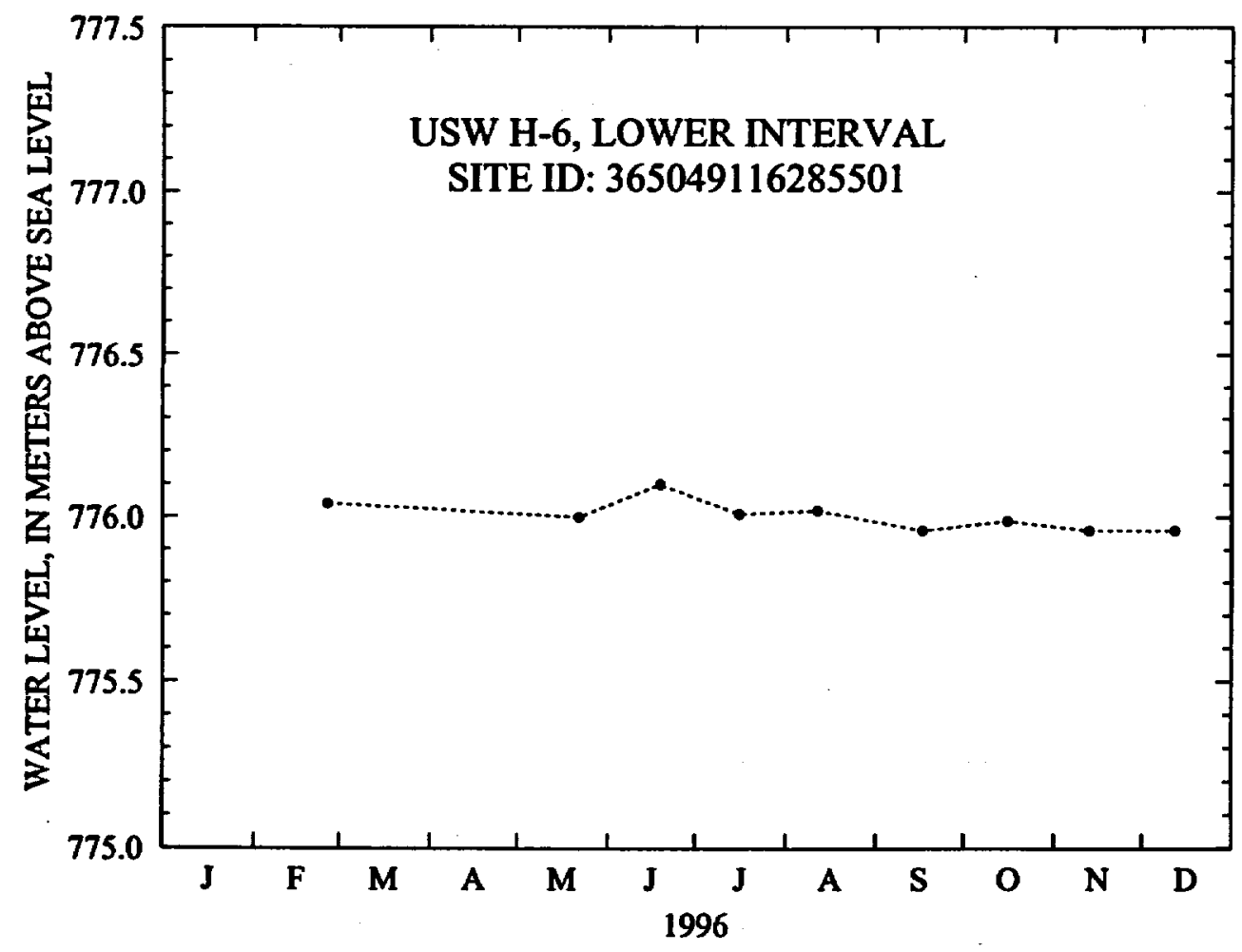

Figure 29. Water-level altitudes, 1996, for well USW H-6, lower interval. 


\section{Well UE-25 J-11}

Information about the history of well UE-25 J-11 and about previous data from the well was obtained from Young (1972) and Fenix \& Scisson, Inc. (1987c).

Well specifications

1. Location and identification:

Latitude and longitude: $36^{\circ} 47^{\prime} 06^{\prime \prime N}$.; $116^{\circ} 17^{\prime} 06^{\prime \prime} \mathrm{W}$.

Nevada State Central Zone Coordinates (m): N 225,847; E 186,466.

U.S. Geological Survey Site ID: 364706116170601.

2. Drilling and casing information:

Well started: June 4, 1957.

Well completed: July 19, 1957.

Drilling method: Cable-tool.

Bit diameter below water level: $400 \mathrm{~mm}$.

Casing extending below water level: 308 -mm-inside-diameter casing extends from land surface to $404.5 \mathrm{~m}$.

Total drilled depth: $405 \mathrm{~m}$.

3. Access to and description of depth interval for measuring water levels:

308-mm-inside-diameter casing; the casing is perforated from 328.3 to $334.4 \mathrm{~m}$ and from 379.2 to $396.2 \mathrm{~m}$. The well produces water from the basalt of Kiwi Mesa and from the welded-tuff aquifer, located within the Topopah Spring Tuff of the Paintbrush Group.

4. Information for calculating water-level altitude:

Reference point: Chiseled " $X$ " in concrete pad near well; altitude $1,049.45 \mathrm{~m}$ (surveyed by U.S. Geological Survey in 1993).

Measuring point: Top of casing, even with top of concrete block, $0.555 \mathrm{~m}$ above reference point.

Depth correction for borehole deviation from vertical is not available.

Well UE-25 J-11 was measured periodically during 1996, and water-level altitudes for well UE-25 J-11 ranged from 732.18 to $732.32 \mathrm{~m}$ above sea level in 1996. The mean water-level altitude of the 1996 data was $732.25 \mathrm{~m}$ above sea level. This mean altitude was the same as the mean altitude of $732.25 \mathrm{~m}$ for 1995 (Graves and Goemaat, 1998) and $0.04 \mathrm{~m}$ higher than the mean altitude of $732.21 \mathrm{~m}$ for $1985-95$ (Graves and others, 1997). The measured water-level altitudes are listed in table 36 and shown in figure 30 . 
Table 36. Measured water-level altitudes, 1996, for well UE-25 J-11

\begin{tabular}{ccc}
\hline Date & $\begin{array}{c}\text { Measured water-level attifude } \\
\text { (meters above sea level) }\end{array}$ & Method of measuring water level \\
\hline $02-28-96$ & 732.23 & Chain \#3 \\
$05-28-96$ & 732.23 & Chain \#3 \\
$06-24-96$ & 732.30 & Chain \#3 \\
$07-18-96$ & 732.27 & Chain \#3 \\
$08-15-96$ & 732.32 & Chain \#3 \\
$09-18-96$ & 732.28 & Chain \#3 \\
$10-22-96$ & 732.19 & Chain \#3 \\
$11-18-96$ & 732.24 & Chain \#3 \\
$12-16-96$ & 732.18 & Chain \#3 \\
\hline
\end{tabular}

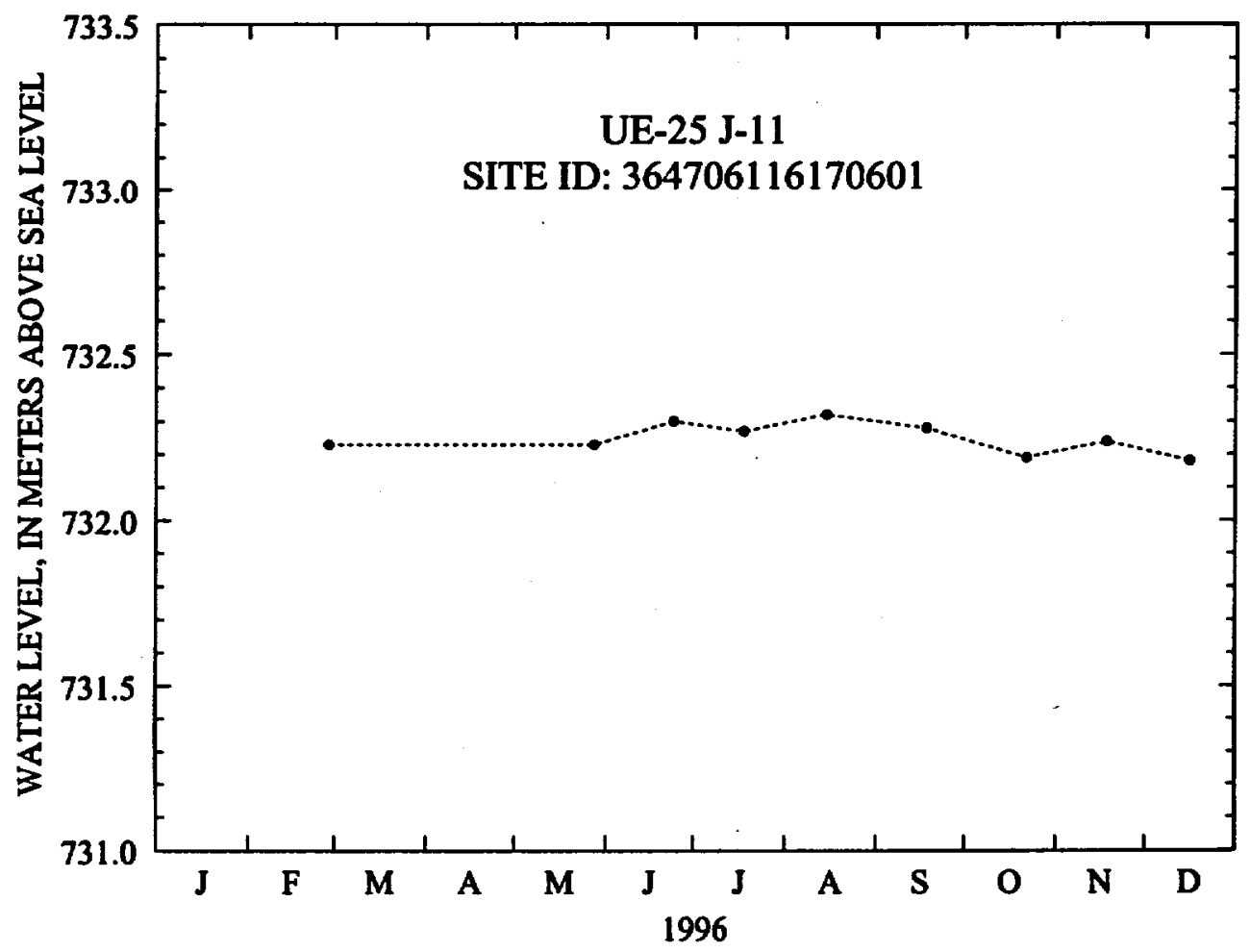

Figure 30. Water-level altitudes, 1996, for well UE-25 J-11. 


\section{Well UE-25 J-12}

Information about the history of well UE-25 J-12 and about previous data from the well was obtained from Young (1972) and Fenix \& Scisson, Inc. (1987c).

Well specifications

1. Location and identification:

Latitude and longitude: $36^{\circ} 45^{\prime} 54^{\prime \prime} \mathrm{N}$.; $116^{\circ} 23^{\prime} 24^{\prime \prime} \mathrm{W}$.

Nevada State Central Zone Coordinates (m): N 223,574; E 177,093.

U.S. Geological Survey Site ID: 364554116232401.

2. Drilling and casing information:

Well started: August 4, 1957.

Well completed: October 9, 1957; well was deepened in August 1968.

Drilling method: Cable-tool (1957); unknown (1968).

Bit diameter below water level: $400 \mathrm{~mm}$ to $271 \mathrm{~m} ; 298 \mathrm{~mm}$ to $347 \mathrm{~m}$.

Casing extending below water level: 308 -mm-inside-diameter casing extending from land surface to $271 \mathrm{~m}$.

Total drilled depth: $271 \mathrm{~m}$ (1957); $347 \mathrm{~m}$ after the deepening in 1968.

3. Access to and description of depth interval for measuring water levels:

308-mm-inside-diameter casing; the casing is perforated between $241-264 \mathrm{~m}$; the hole is open from $271 \mathrm{~m}$ to $347 \mathrm{~m}$; access tube is $54-\mathrm{mm}$ outside diameter. The well produces water from the welded-tuff aquifer, located within the Topopah Spring Tuff of the Paintbrush Group.

4. Information for calculating water-level altitude:

Reference point: Top of well collar, altitude $954.54 \mathrm{~m}$ (surveyed by U.S. Geological Survey in 1993).

Measuring point: Top of the 54-mm-outside-diameter access tube, $0.195 \mathrm{~m}$ above reference point.

Depth correction for borehole deviation from vertical is not available.

5. The amount of water pumped from well UE-25 J-12 in 1996 was approximately 163 million liters (R.A. LaCamera, U.S. Geological Survey, written commun., 1998).

Well UE-25 J-12 was measured periodically during 1996, and water-level altitudes ranged from 727.81 to $727.92 \mathrm{~m}$ above sea level in 1996 . The mean water-level altitude of the 1996 data was $727.86 \mathrm{~m}$ above sea level. This mean altitude was $0.04 \mathrm{~m}$ lower than the mean altitude of $727.90 \mathrm{~m}$ for 1995 (Graves and Goemaat, 1998) and $0.07 \mathrm{~m}$ lower than the mean altitude of $727.93 \mathrm{~m}$ for $1985-95$ (Graves and others, 1997). The measured water-level altitudes are listed in table 37 and shown in figure 31. 
Table 37. Measured water-level altitudes, 1996, for well UE-25 J-12

\begin{tabular}{ccc}
\hline Date & $\begin{array}{c}\text { Measured water-level alttude } \\
\text { (meters above sea level) }\end{array}$ & Method of measuring water level \\
\hline $02-07-96$ & 727.87 & Chain \#3 \\
$05-28-96$ & 727.86 & Chain \#3 \\
$06-24-96$ & 727.89 & Chain \#3 \\
$07-18-96$ & 727.85 & Chain \#3 \\
$08-15-96$ & 727.84 & Chain \#3 \\
$09-18-96$ & 727.81 & Chain \#3 \\
$10-23-96$ & 727.92 & Chain \#3 \\
$11-18-96$ & 727.83 & Chain \#3 \\
$12-16-96$ & 727.86 & Chain \#3 \\
\hline
\end{tabular}

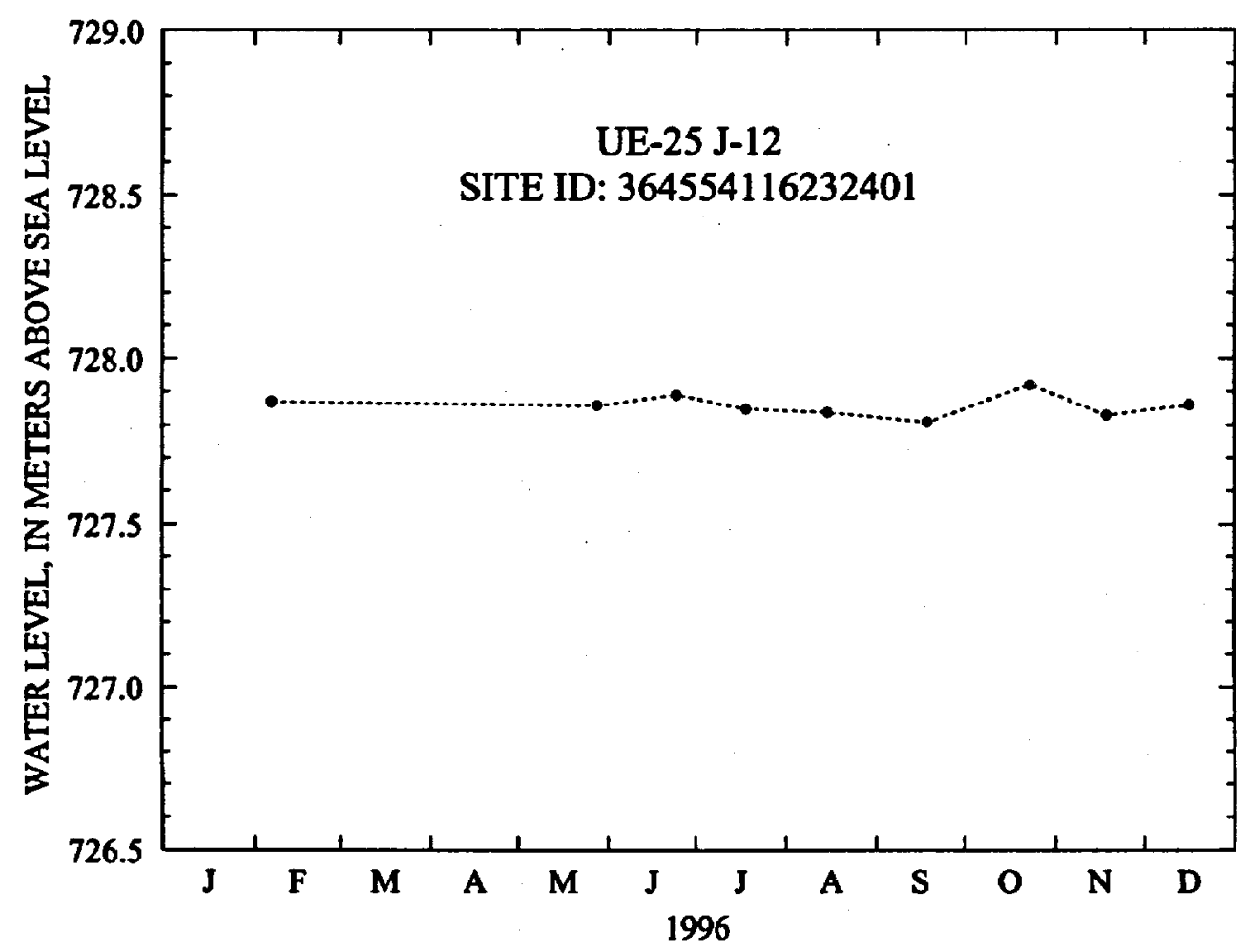

Figure 31. Water-level altitudes, 1996, for well UE-25 J-12. 


\section{Well UE-25 J-13}

Information about the history of well UE-25 J-13 and about previous data from the well was obtained from various sources. These sources are: Robison (1984); J.H. Robison (U.S. Geological Survey, written commun., 1986); Robison and others (1988); Holmes \& Narver, Inc. (written commun., 1986); Thordarson (1983); Young (1972); and Fenix \& Scisson, Inc. (1987c).

Well specifications

1. Location and identification:

Latitude and longitude: $36^{\circ} 48^{\prime} 29^{\prime \prime} \mathrm{N}$.; $116^{\circ} 23^{\prime} 40^{\prime \prime} \mathrm{W}$.

Nevada State Central Zone Coordinates (m): N 228,359; E 176,678.

U.S. Geological Survey Site ID: 364828116234001.

2. Drilling and casing information:

Well started: September 12, 1962.

Well completed: January 8, 1963.

Drilling method: Rotary, using air and aerated mud as circulating medium.

Bit diameter below water level: $438 \mathrm{~mm}$ to $402 \mathrm{~m} ; 380 \mathrm{~mm}$ from $402 \mathrm{~m}$ to $471 \mathrm{~m}$; $194 \mathrm{~mm}$ from $471 \mathrm{~m}$ to total depth.

Casing extending below water level: $323-\mathrm{mm}$ inside diameter, from land surface to $396.5 \mathrm{~m} ; 282-\mathrm{mm}$ inside diameter from 396.5 to $471.2 \mathrm{~m} ; 126-\mathrm{mm}$ inside diameter from 452.3 to $1,031.7 \mathrm{~m}$; casing perforated from 303.6 to $423.7 \mathrm{~m}$ is within the Topopah Spring Tuff of the Paintbrush Group and from 819.9 to $1,009.5 \mathrm{~m}$ is within the Tram Tuff of the Crater Flat Group and upper part of the Lithic Ridge Tuff.

Total drilled depth: $1,063 \mathrm{~m}$.

3. Access to and description of depth interval for measuring water levels:

50.8-mm-inside-diameter access tube, installed in 1986, in order for measuring equipment to bypass pump assembly.

4. Information for calculating water-level altitude:

Reference point: Chiseled square on concrete well collar, altitude $1,011.47 \mathrm{~m}$ above reference point (surveyed by U.S. Geological Survey in 1984).

Measuring point: Top of access tube, $0.165 \mathrm{~m}$.

Depth correction for borehole deviation from vertical is not available.

5. The amount of water pumped from well UE-25 J-13 in 1996 was approximately 105 million liters (R.A. LaCamera, U.S. Geological Survey, written commun., 1998).

Well UE-25 J-13 was measured periodically during 1996 and water-level altitudes ranged from 728.22 to $728.44 \mathrm{~m}$ above sea level in 1996. The mean water-level altitude of the 1996 data was $728.36 \mathrm{~m}$ above sea level. This mean altitude was $0.07 \mathrm{~m}$ lower than the mean altitude of $728.43 \mathrm{~m}$ for 1995 (Graves and Goemaat, 1998) and $0.08 \mathrm{~m}$ lower than the mean altitude of $728.44 \mathrm{~m}$ for 1985-95 (Graves and others, 1997). The measured water-level altitudes are listed in table 38 and shown in figure 32. 
As mentioned for wells USW WT-10, USW H-1, tubes $1,2,3$, and 4, and USW H-6, lower interval, well UE-25 J-13 had a sudden rise in water level during June 1996. In well UE-25 J-13, the water level rose only about $0.05 \mathrm{~m}$ from May to June 1996. By July 1996, the water level declined back to a water level slightly lower than the May water level.

Table 38. Measured water-level altitudes, 1996, for well UE-25 J-13

\begin{tabular}{ccc}
\hline Date & $\begin{array}{c}\text { Measured water-level altitude } \\
\text { (meters above sea level) }\end{array}$ & Method of measuring water level \\
\hline $02-07-96$ & 728.40 & Chain \#3 \\
$05-28-96$ & 728.39 & Chain \#3 \\
$06-24-96$ & 728.44 & Chain \#3 \\
$07-18-96$ & 728.37 & Chain \#3 \\
$08-15-96$ & 728.35 & Chain \#3 \\
$09-18-96$ & 728.35 & Chain \#3 \\
$10-24-96$ & 728.34 & Chain \#3 \\
$11-18-96$ & 728.35 & Chain \#3 \\
$12-16-96$ & 728.22 & Chain \#3 \\
\hline
\end{tabular}

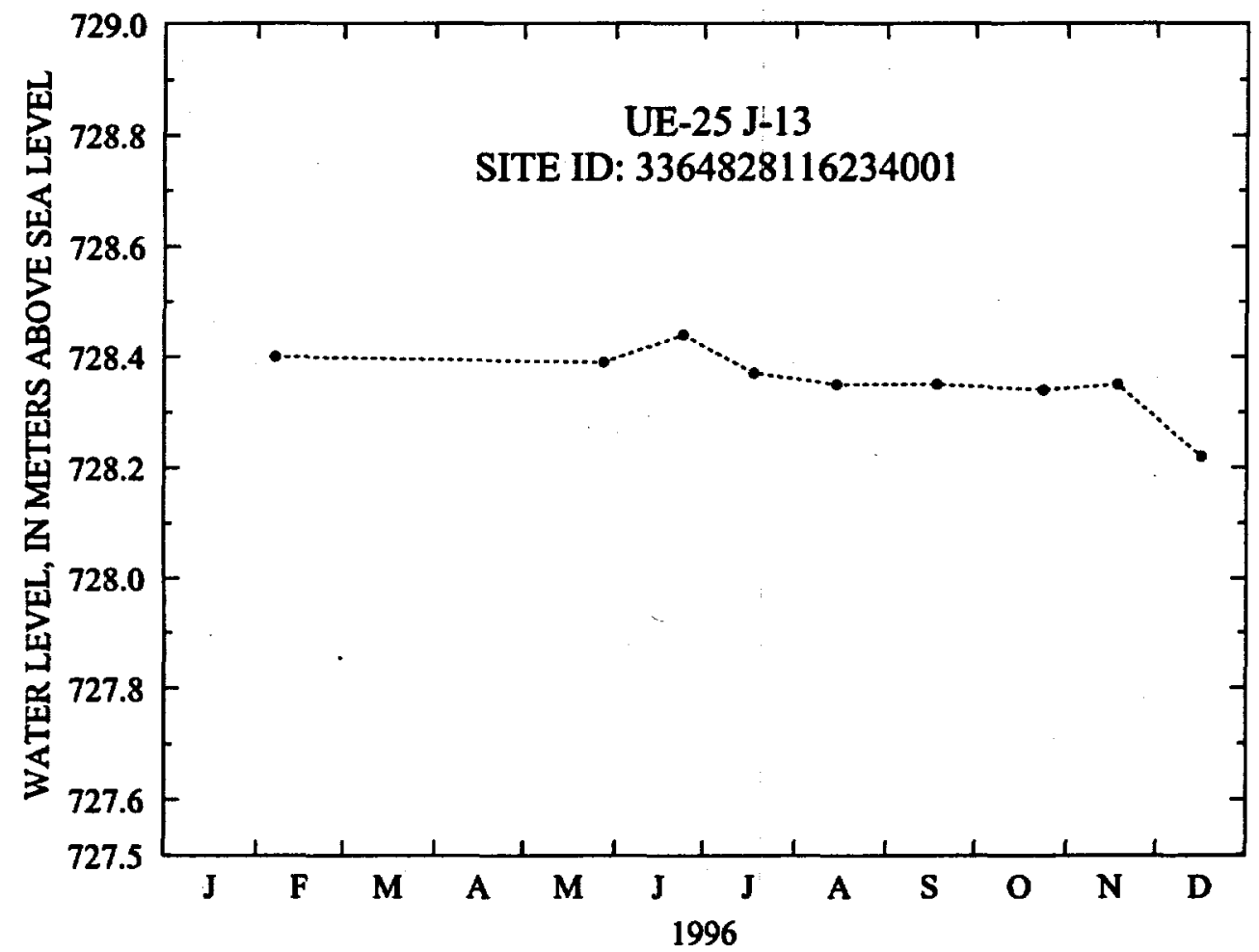

Figure 32. Water-level altitudes, 1996, for well UE-25 J-13. 


\section{REFERENCES CITED}

Bentley, C.B., Robison, J.H., and Spengler, R.W., 1983, Geohydrologic data for test well USW H-5, Yucca Mountain area, Nye County, Nevada: U.S. Geological Survey Open-File Report 83-853, 34 p.

Blee, J.W.H., Herlong, H.E., Kauffman, C.D., Jr., Hardee, J.H., Field, M.L., and Middelburg, R.F., Jr., 1986, GOES data-collection system instrumentation, installation, and maintenance manual: U.S. Geological Survey OpenFile Report 86-479, various pagination.

Boucher, M.S., 1994a, Precision and accuracy of manual water-level measurements taken in the Yucca Mountain area, Nye County, Nevada, 1988-90: U.S. Geological Survey Water-Resources Investigations Report 93$4025,18 \mathrm{p}$.

Boucher, M.S., 1994b, Water levels in wells J-11 and J-12, 1989-91, Yucca Mountain area, Nevada: U.S. Geological Survey Open-File Report 94-303, 9 p.

Byers, F.M., Jr., Carr, W.J., Orkild, P.P., Quinlivan, W.D., and Sargent, K.A., 1976, Volcanic suites and related cauldrons of Timber Mountain-Oasis Valley caldera complex, southern Nevada: U.S. Geological Survey Professional Paper 919, 70 p.

Carr, W.J., 1988, Volcano-tectonic setting of Yucca Mountain and Crater Flat, southwestern Nevada, in Carr, M.D., and Yount, J.C., eds., Geologic and hydrologic investigations of a potential nuclear waste disposal site at Yucca Mountain, southern Nevada: U.S. Geological Survey Bulletin 1790, p. 35-49.

Carr, W.J., Byers, F.M., Jr., and Orkild, P.P., 1986, Stratigraphic and volcano-tectonic relations of Crater Flat Tuff and some older volcanic units, Nye County, Nevada: U.S. Geological Survey Professional Paper 1323, 28 p.

Craig, R.W., and Johnson, K.A., 1984, Geohydrologic data for test well UE-25 p\#1, Yucca Mountain area, Nye County, Nevada: U.S. Geological Survey Open-File Report 84-450, 63 p.

Craig, R.W., Reed, R.L., and Spengler, R.W., 1983, Geohydrologic data for test well USW H-6, Yucca Mountain area, Nye County, Nevada: U.S. Geological Survey Open-File Report 83-856, 35 p.

Craig, R.W., and Robison, J.H., 1984, Geohydrology of test well UE-25 p\#1, Yucca Mountain area, Nye County, Nevada: U.S. Geological Survey Water-Resources Investigations Report 84-4248, 57 p.

Erickson, J.R., and Waddell, R.K., 1985, Identification and characterization of hydrologic properties of fractured tuff using hydraulic and tracer tests-Test well USW H-4, Yucca Mountain, Nye County, Nevada: U.S. Geological Survey Water-Resources Investigations Report 85-4066, $30 \mathrm{p}$.

Fenix \& Scisson, Inc., 1986a, NNWSI hole histories-UE-25 WT\#3, UE-25 WT\#4, UE-25 WT\#5, UE-25 WT\#6, UE-25 WT\#12, UE-25 WT\#13, UE-25 WT\#14, UE-25 WT\#15, UE-25 WT\#16, UE-25 WT\#17, UE-25 WT\# 18, USW WT-1, USW WT-2, USW WT-7, USW WT-10, USW WT-11: U.S. Department of Energy DOENV/10322-10, $111 \mathrm{p}$.

1986b, NNWSI hole history —UE-25 b\#1: U.S. Department of Energy DOE/NV/10322-13, 37 p.

1986c, NNWSI hole history -UE-25 p\#1: U.S. Department of Energy DOE/NV/10322-16, 39 p.

1987a, NNWSI hole histories USW H-1, USW H-3, USW H-4, USW H-5, USW H-6: U.S. Department of Energy DOE/NV/10322-18, 99 p.

1987b, NNWSI hole histories-USW G-1, USW G-2, USW G-3, USW G-4, USW GA-1, USW GU-3:

U.S. Department of Energy DOE/NV/10322-19, 187 p.

1987c, NNWSI drilling and mining summary: U.S. Department of Energy DOE/NV/10322-24, 45 p.

Garber, M.S., and Koopman, F.C., 1968, Methods of measuring water levels in deep wells: U.S. Geological Survey Techniques of Water-Resources Investigations, book 8, chap. A-1, 23 p.

Gemmell, J.M., 1990, Water levels in periodically measured wells in the Yucca Mountain area, Nevada, 1988:

U.S. Geological Survey Open-File Report 90-113, 47 p.

Graves, R.P., and Goemaat, R.L., 1998, Water levels in the Yucca Mountain area, Nevada, 1995: U.S. Geological Survey Open-File Report 97-101, 92 p.

Graves, R.P., Tucci, Patrick, and Goemaat, R.L., 1996, Water levels in the Yucca Mountain area, Nevada, 1994: U.S. Geological Survey Open-File Report 95-757, 101 p.

Graves, R.P., Tucci, Patrick, and O'Brien, G.M., 1997, Analysis of water-level data in the Yucca Mountain area, Nevada, 1985-95: U.S. Geological Survey Water-Resources Investigations Report 96-4256, 140 p.

Lahoud, R.G., Lobmeyer, D.H., and Whitfield, M.S., Jr., 1984, Geohydrology of volcanic tuff penetrated by test well UE-25 b\#1, Yucca Mountain, Nye County, Nevada: U.S. Geological Survey Water-Resources Investigations Report 84-4253, 44 p. 
Lobmeyer, D.H., Luckey, R.R., O'Brien, G.M., and Burkhardt, D.J., 1995, Water levels in continuously monitored wells in the Yucca Mountain area, Nevada, 1989: U.S. Geological Survey Open-File Report 93-098, 173 p.

Lobmeyer, D.H., Whitfield, M.S., Jr., Lahoud, R.G., and Bruckheimer, Laura, 1983, Geohydrologic data for test well UE-25 b\#1, Nevada Test Site, Nye County, Nevada: U.S. Geological Survey Open-File Report 83-855, 48 p.

Luckey, R.R., Lobmeyer, D.H., and Burkhardt, Douglas, 1993, Water levels in continuously monitored wells in the Yucca Mountain area, Nevada, 1985-88: U.S. Geological Survey Open-File Report 91-493, 252 p.

Maldonado, Florian, and Koether, S.L., 1983, Stratigraphy, structure, and some petrographic features of Tertiary volcanic rocks at the USW G-2 Drill Hole, Yucca Mountain, Nye County, Nevada: U.S. Geological Survey Open-File Report 83-732, $83 \mathrm{p}$.

Nelson, P.H., Muller, D.C., Schimschal, Ulrich, and Kibler, J.E., 1991, Geophysical logs and core measurements from forty boreholes at Yucca Mountain, Nevada: U.S. Geological Survey Geophysical Investigations Map GP-1001, 64 p., 40 pls.

Nelson, P.H., and Schimschal, Ulrich, 1993, Assessment of geophysical logs from borehole USW G-2, Yucca Mountain, Nevada: U.S. Geological Survey Open-File Report 92-572, 34 p.

O'Brien, G.M., 1991, Water levels in periodically measured wells in the Yucca Mountain area, Nevada, 1989: U.S. Geological Survey Open-File Report 91-178, 51 p. 1992, Earthquake-induced water-level fluctuations at Yucca Mountain, Nevada, April, 1992: U.S. Geological Survey Open-File Report 92-137, 10 p. 1993, Earthquake-induced water-level fluctuations at Yucca Mountain, Nevada, June, 1992: U.S. Geological Survey Open-File Report 93-73, 12 p.

O'Brien, G.M., Tucci, Patrick, and Burkhardt, D.J., 1995, Water levels in the Yucca Mountain area, Nevada, 1992: U.S. Geological Survey Open-File Report 94-311, 74 p.

Robison, J.H., 1984, Ground-water level data and preliminary potentiometric surface maps, Yucca Mountain and vicinity, Nye County, Nevada: U.S. Geological Survey Water-Resources Investigations Report 84-4197, 8 p.

Robison, J.H., Stephens, D.M., Luckey, R.R., and Baldwin, D.A., 1988, Water levels in periodically measured wells in the Yucca Mountain area, Nevada, 1981-87: U.S. Geological Survey Open-File Report 88-468, 132 p.

Rush, F.E., Thordarson, William, and Bruckheimer, Laura, 1983, Geohydrologic and drill-hole data for test well USW H-1, adjacent to Nevada Test Site, Nye County, Nevada: U.S. Geological Survey Open-File Report 83-141, 38 p.

Rush, F.E., Thordarson, William, and Pyles, D.G., 1984, Geohydrology of test well USW H-1, Yucca Mountain, Nye County, Nevada: U.S. Geological Survey Water-Resources Investigations Report 84-4032, 56 p.

Sass, J.H., and Lachenbruch, A.H., 1982, Preliminary interpretation of thermal data from the Nevada Test Site: U.S. Geological Survey Open-File Report 82-973, 30 p.

Sawyer, D.A., Fleck, R.J., Lanphere, M.A., Warren, R.G., Broxton, M.R., 1994, Episodic caldera volcanism in the Miocene southwestern Nevada volcanic field-Revised stratigraphic framework, ${ }^{40} \mathrm{Ar} /{ }^{39} \mathrm{Ar}$ geochronology, and implications for magmatism and extension: Geological Society of America Bulletin, v. 106, p. 1304-1418.

Thordarson, William, 1983, Geohydrologic data and test results from well J-13, Nevada Test Site, Nye County, Nevada: U.S. Geological Survey Water-Resources Investigations Report 83-4171, 57 p.

Thordarson, William, and Howells, Lewis, 1987, Hydraulic tests and chemical quality of water at well USW VH-1, Crater Flat, Nye County, Nevada: U.S. Geological Survey Water-Resources Investigations Report 86-4359, 20 p.

Thordarson, William, Rush, F.E., Spengler, R.W., and Waddell, S.J., 1984, Geohydrologic and drill-hole data for test well USW H-3, Yucca Mountain, Nye County, Nevada: U.S. Geological Survey Open-File Report 84-149, 54 p.

Thordarson, William, Rush, F.E., and Waddell, S.J., 1984, Geohydrology of test well USW H-3, Yucca Mountain, Nye County, Nevada: U.S. Geological Survey Water-Resources Investigations Report 84-4272, 38 p.

Tucci, Patrick, O'Brien, G.M., and Burkhardt, D.J., 1996, Water levels in the Yucca Mountain area, Nevada, 1990-91: U.S. Geological Survey Open-File Report 94-111, 107 p.

Tucci, Patrick, Goemaat R.L., and Burkhardt, D.J., 1996, Water levels in the Yucca Mountain area, Nevada, 1993: U.S. Geological Survey Open-File Report 95-159, 94 p.

U.S. Department of Energy, 1988, Site characterization plan, Yucca Mountain site, Nevada research and development area, Nevada: U.S. Department of Energy Report DOE RW/0199, 8 v., various pagination.

Whitfield, M.S., Jr., Eshom, E.P., Thordarson, William, and Schaefer, D.H., 1985, Geohydrology of rocks penetrated by test well USW H-4, Yucca Mountain, Nye County, Nevada: U.S. Geological Survey Water-Resources Investigations Report 85-4030, 33 p.

Whitfield, M.S., Jr., Thordarson, William, and Eshom, E.P., 1984, Geohydrologic and drill-hole data for test well USW H-4, Yucca Mountain, Nye County, Nevada: U.S. Geological Survey Open-File Report 84-449, 39 p. 
Winograd, 1.J., and Thordarson, William, 1975, Hydrogeologic and hydrochemical framework, south-central Great Basin, Nevada-California, with special reference to the Nevada Test Site: U.S. Geological Survey Professional Paper 712-C, $126 \mathrm{p}$.

Young, R.A., 1972, Water supply for the Nuclear Rocket Development Station at the U.S. Atomic Energy Commission's Nevada Test Site: U.S. Geological Survey Water-Supply Paper 1938, 19 p. 
The distribution code for this report is UC-814. 
YMP-USGS Open File Report 98-169 Record

Subject/Title: Water Levels in the Yucca Mountain Area, Nevada, 1996

Record date: $5 / 08 / 98$

Author: Robert P. Graves Organization: USGS

Identifiers: . USGS OFR 98-169

Traceability designators:

SCP: 8.3.1.2.3.1.2

WBS: 1.2.3.3.1.3.1

DTN:GS980308312312.004

QA designator: $\quad$ QA:L 